\title{
Evaluatie arbeidsmarktprognoses naar opleiding en beroep tot 1994
}

Citation for published version (APA):

Borghans, L., van Eijs, P. W. L. J., \& Smits, W. (1996). Evaluatie arbeidsmarktprognoses naar opleiding en beroep tot 1994. Researchcentrum voor Onderwijs en Arbeidsmarkt, Faculteit der Economische Wetenschappen. ROA Reports No. 9 https://doi.org/10.26481/umarep.1996009

Document status and date:

Published: 01/01/1996

DOI:

10.26481/umarep.1996009

Document Version:

Publisher's PDF, also known as Version of record

\section{Please check the document version of this publication:}

- A submitted manuscript is the version of the article upon submission and before peer-review. There can be important differences between the submitted version and the official published version of record.

People interested in the research are advised to contact the author for the final version of the publication, or visit the DOI to the publisher's website.

- The final author version and the galley proof are versions of the publication after peer review.

- The final published version features the final layout of the paper including the volume, issue and page numbers.

Link to publication

\footnotetext{
General rights rights.

- You may freely distribute the URL identifying the publication in the public portal. please follow below link for the End User Agreement:

www.umlib.nl/taverne-license

Take down policy

If you believe that this document breaches copyright please contact us at:

repository@maastrichtuniversity.nl

providing details and we will investigate your claim.
}

Copyright and moral rights for the publications made accessible in the public portal are retained by the authors and/or other copyright owners and it is a condition of accessing publications that users recognise and abide by the legal requirements associated with these

- Users may download and print one copy of any publication from the public portal for the purpose of private study or research.

- You may not further distribute the material or use it for any profit-making activity or commercial gain

If the publication is distributed under the terms of Article $25 \mathrm{fa}$ of the Dutch Copyright Act, indicated by the "Taverne" license above, 


\title{
Evaluatie arbeidsmarktprognoses naar opleiding en beroep tot 1994
}

ROA-R-1996/9

\author{
Lex Borghans \\ Patrick van Eijs \\ Wendy Smits
}

Researchcentrum voor Onderwijs en Arbeidsmarkt

Faculteit der Economische Wetenschappen en Bedrijfskunde Universiteit Maastricht

Maastricht, oktober 1996 
ISBN 90-5321-188-8 


\section{Inhoud}

Bladzijde

1 Inleiding 1

1.1 Voorgeschiedenis 1

1.2 Uitgangspunten voor de evaluatie $\quad 2$

1.3 Doel en opzet prognoses 3

$\begin{array}{ll}1.4 \text { Opzet van het rapport } & 9\end{array}$

2 Een methode voor de empirische evaluatie $\quad 11$

2.1 Inleiding 11

2.2 Het evaluatiecriterium 11

2.3 De oorzaak van voorspelfouten 14

$\begin{array}{ll}2.4 \text { De evaluatie van kwalitatieve typeringen } & 18\end{array}$

$\begin{array}{ll}2.5 \text { Vergelijken met ander prognoses } & 19\end{array}$

3 De uitbreidingsvraag 23

3.1 Inleiding 23

3.2 Prognoses uitbreidingsvraag 23

3.3 Empirische analyse uitbreidingsvraagprognoses 28

3.4 Een vergelijking met eerdere uitbreidingsvraagprognoses 45

$\begin{array}{ll}3.5 \text { Conclusies } & 49\end{array}$

4 Vervangingsvraag per beroepsklasse $\quad 51$

4.1 Inleiding $\quad 51$

4.2 Prognosemethodiek $\quad 51$

4.3 Empirische analyse vervangingsvraagprognoses per beroepsklasse $\quad 54$

4.4 Empirische analyse vervangingsvraagprognoses per opleidingstype $\quad 72$

5 Baanopeningen $\quad 79$

$\begin{array}{ll}5.1 \text { Inleiding } & 79\end{array}$

$\begin{array}{ll}5.2 \text { Prognosemethodiek } & 79\end{array}$

$\begin{array}{ll}5.3 \text { Empirische analyse prognoses baanopeningen } & 80\end{array}$

6 De instroom van schoolverlaters $\quad 91$

$\begin{array}{ll}6.1 \text { Inleiding } & 91\end{array}$

$\begin{array}{ll}\text { 6.2 Methodiek van instroomprognoses } & 91\end{array}$

6.3 Een empirische evaluatie van de instroomprognoses 95

$\begin{array}{lr}6.4 \text { Conclusies } & 105\end{array}$ 
7 Confrontatie van vraag en aanbod $\quad 107$

$\begin{array}{ll}7.1 \text { Inleiding } & 107\end{array}$

$\begin{array}{ll}7.2 \mathrm{De} \text { indicator toekomstige arbeidsmarktsituatie } & 107\end{array}$

$\begin{array}{ll}\text { 7.3 Evaluatie van de toekomstige arbeidsmarktperspectieven } & 108\end{array}$

$\begin{array}{ll}7.4 \text { Conclusies } & 112\end{array}$

8 Een vergelijking met de uitbreidingsvraagprognoses van BLS 113

$\begin{array}{ll}8.1 \text { Inleiding } & 113\end{array}$

$\begin{array}{ll}\text { 8.2 Arbeidsmarktprognoses van BLS } & 114\end{array}$

8.3 Verschillen in voorspelkwaliteit tussen ROA en BLS 116

$\begin{array}{ll}9 \text { Conclusies } & 121\end{array}$

$\begin{array}{lr}\text { Literatuur } & 129\end{array}$ 


\section{Inleiding}

\subsection{Voorgeschiedenis}

In het kader van het informatiesysteem onderwijs-arbeidsmarkt maakt het Researchcentrum voor Onderwijs en Arbeidsmarkt (ROA) sinds 1989 regelmatig middellange-termijnprognoses voor de arbeidsmarktperspectieven van opleidingen en beroepen. Dit informatiesysteem wordt financieel mogelijk gemaakt door het Ministerie van Onderwijs, Cultuur en Wetenschappen, het Centraal Bestuur voor de Arbeidsvoorziening en het Landelijk Dienstverlenend Centrum voor studie- en beroepskeuzevoorlichting (LDC). Het doel van het informatiesysteem is om de transparantie van de relatie tussen het onderwijs en de arbeidsmarkt te vergroten. Een beter inzicht in de actuele situatie en de toekomstige ontwikkelingen op de arbeidsmarkt, kan de beslissingen van degenen die betrokken zijn bij het onderwijs ondersteunen. In de eerste plaats kan hierbij gedacht worden aan het streven informatie te verschaffen die bruikbaar is voor studie- en beroepskeuze. Daarnaast blijkt ook voor de overheid als grootste investeerder in het onderwijs, de arbeidsvoorzieningsorganisatie, scholen en het bedrijfsleven goede informatie over de aansluiting tussen onderwijs en arbeidsmarkt van belang.

Om te bewerkstelligen dat de arbeidsmarktinformatie en -prognoses ook daadwerkelijk ter beschikking van de studiekiezers kwamen werd deze informatie aanvankelijk gebruikt voor de invulling van de arbeidsmarktmodule van I See! Dit was een geautomatiseerd informatiesysteem, tot stand gebracht door het LDC, dat uit vele bronnen informatie over studie- en beroepskeuze bij elkaar bracht. Schooldekanen en andere intermediairs die betrokken zijn bij de keuzebegeleiding van leerlingen konden deze informatie via hun personal computer raadplegen en kregen zo, naast de andere informatie over studie- en beroepskeuze, ook zicht op de arbeidsmarktconsequenties van de keuzemogelijkheden. Thans is de arbeidsmarktinformatie van het ROA opgenomen in de op CD-ROM verkrijgbare voorlichtingsprodukten voor studie- en beroepskeuze die zijn uitgebracht in de Traject-reeks en de in boekvorm gepubliceerde serie Beroep en werk. Geheel toegesneden op de verspreiding van de arbeidsmarktinformatie voor studiekiezers is de LDC-publikatie Kansen op werk 2000, Arbeidsmarktperspectieven van opleidingen en beroepen. Voor de andere, beleidsmatige, gebruikers van het informatiesysteem worden de gegevens uit het informatiesysteem gepresenteerd in het ROA-rapport De arbeidsmarkt naar opleiding en beroep tot.... Inmiddels zijn er, afgezien van een pilot-onderzoek uit 1987, vijf maal dergelijke arbeidsmarktprognoses opgesteld. In 1989 betrof dit prognoses voor 1992; in 1990 en 1991 zijn de prognoses naar opleiding en beroep tot 1994 opgesteld; in 1993 betrof dit prognoses tot 1998; en onlangs (1995) werden prognoses voor de arbeidsmarkt naar opleiding en beroep tot 2000 voltooid. 
Het informatiesysteem onderwijs-arbeidsmarkt heeft sinds de start in 1987 een sterke ontwikkeling doorgemaakt. Dit was mogelijk doordat naast de feitelijke prognose-activiteiten toegespitste studies worden verricht die ten doel hebben de kwaliteit van de gehanteerde modellen en de bruikbaarheid van de gebruikte typeringen en indicatoren te vergroten. Deze ontwikkeling wordt gevoed door de concrete ervaringen die zijn opgedaan bij het opstellen van de prognoses, maar ook door het uitvoeren van gerichte evaluatiestudies. De eerste prognoses die betrekking hadden op de periode 1985-1992 zijn reeds voorlopig geëvalueerd in De Grip, Heijke en Berendsen (1991) en uiteindelijk in Borghans, Van Eijs en De Grip (1994). Daarnaast kan gewezen worden op de Herijking van het informatiesysteem onderwijs-arbeidsmarkt (Borghans, De Grip en Willems, 1995) waarin de uitgangs-punten van de gehanteerde structuur van het informatiesysteem opnieuw zijn geformuleerd. In dit rapport wordt deze lijn voortgezet door de prognoses voor 1994 te evalueren.

Er zijn, zoals reeds werd opgemerkt, twee maal prognoses voor 1994 opgesteld. Vanwege de overgang bij het Centraal Bureau voor de Statistiek (CBS) van de Arbeids-Krachten-Telling (AKT) naar de Enquête Beroeps-Bevolking (EBB) was er sprake van een vertraagde beschikbaarheid van gegevens. Om die reden werd bij de prognoses die in 1991 zijn opgesteld (ROA, 1992a en b) besloten de prognosehorizon niet verder te leggen dan bij de prognoses die in 1990 tot stand kwamen (Dekker e.a., 1990 en ROA, 1991). Omdat de prognoses uit 1991 een aantal vernieuwingen in de methodiek bevatten ten opzichte van de prognoses uit 1990 (Zie Dekker e.a., 1992), wordt in dit evaluatierapport ingegaan op deze meest recente prognoses voor 1994. Dit heeft bovendien als voordeel dat bij deze prognoses dezelfde beroepenclassificatie werd gehanteerd als thans gebruikt wordt. Dit evaluatierapport zal eenzelfde lijn volgen als de vorige evaluatie. Naast de empirische evaluatie bevat dit rapport ook een terugblik op de gehanteerde methodiek, waarbij wordt ingegaan op de sterke en zwakke punten van die aanpak en mogelijke verbeteringen en uitbreidingsmogelijkheden van het informatiesysteem. Bovendien zal de kwaliteit van de prognoses voor de periode 1989-1994 zoveel mogelijk worden vergeleken met de kwaliteit van de eerdere prognoses.

\subsection{Uitgangspunten voor de evaluatie}

In het vorige evaluatierapport werd reeds opgemerkt dat hoewel een evaluatie in eerste instantie vooral terugblikt naar het moment waarop de prognose werd opgesteld en naar de periode waarop de prognoses betrekking hadden, een evaluatie vooral van belang is met het oog op toekomstige prognoseactiviteiten. Hierbij kunnen een drietal belanghebbenden worden onderscheiden.

Voor de gebruikers van de prognoses over de toekomstige arbeidsmarkt naar opleiding en beroep is het nuttig informatie te hebben over de mate van 
betrouwbaarheid van de prognoses. In Borghans (1993) wordt getoond dat publieke voorspellingen een positieve invloed op de studiekeuze van leerlingen en daarmee op de werking van de arbeidsmarkt hebben, mits leerlingen een redelijk beeld hebben van de bruikbaarheid van deze prognoses. Voor het inzicht in de bruikbaarheid van de prognoses zijn twee zaken van belang. Ten eerste dient het voor leerlingen duidelijk te zijn op grond van welke argumenten een prognose tot stand is gekomen. Het totaalbeeld dat een prognose schetst dient verbijzonderd te worden naar de componenten waaruit zij is opgebouwd, zodat duidelijk wordt op grond waarvan bepaalde ontwikkelingen verwacht worden. Dit maakt het mogelijk de prognoses te vergelijken met de eigen verwachtingen over de toekomstige arbeidsmarktontwikkelingen en/of diverse andere informatiebronnen. Ten tweede is het van belang dat leerlingen een beeld hebben van de gemiddelde trefzekerheid van de voorspellingen, omdat dit mede bepaalt in welke mate zij rekening zouden moeten houden met de prognoses van het informatiesysteem. Om aan deze eis te voldoen is het derhalve belangrijk na te gaan op welke punten de prognoses redelijk trefzeker zijn, en op welke punten de onzekerheden liggen. Ook moet bekeken worden op welke manier de mate van onzekerheid tot uitdrukking komt in de wijze waarop de prognoses worden gepubliceerd.

Ook voor de opstellers van de prognoses is een goede evaluatie van de prognoses uit het verleden van groot belang. Bij het opstellen van prognoses wordt op basis van inzichten in het functioneren van de arbeidsmarkt een keuze gemaakt tussen de vele mogelijke manieren om de arbeidsmarkt te modelleren. Indien alleen de kwaliteit van de data de kwaliteit van de prognoses zou bepalen, zou de enige les die uit de evaluatie getrokken kan worden, een roep om meer of betere data zijn. Een evaluatie van de prognoses kan echter ook nieuwe inzichten geven over de bruikbaarheid van de gehanteerde methode. Verder kan, nu voor de tweede maal een systematische evaluatie wordt uitgevoerd, worden nagegaan of de aanpassingen die destijds hebben plaatsgevonden in de methodiek, ook in de verwachte verbeteringen hebben geresulteerd.

Als derde groep hebben de opdrachtgevers belang bij een evaluatie van de voorspellingen. Aan de ene kant kan deze evaluatie informatie geven omtrent de prioriteiten die gelegd moeten worden bij de verdere ontwikkeling van het informatiesysteem. Aan de andere kant is het voor de opdrachtgevers belangrijk te weten in hoeverre de prognoses bruikbaar zijn voor de door hen beoogde gebruiksdoelen.

\subsection{Doel en opzet prognoses}

Om te komen tot een evaluatie van de prognoses die in het kader van het informatiesysteem van het ROA zijn gemaakt, moet worden vastgesteld in hoeverre deze prognoses voldoen aan de doeleinden waarvoor ze zijn opgesteld. Daarvoor is 
het belangrijk om een duidelijk beeld te hebben van de algehele prognose-opzet en van de doelstellingen van de prognoses zoals zij destijds zijn gemaakt. Dit maakt het mogelijk om bij de evaluatie zowel te kijken naar de doeltreffendheid van de prognoses, alsook naar de mate waarin de gehanteerde opzet gericht is op de gestelde doelen.

\section{Doelstelling prognoses}

Zoals hierboven reeds werd opgemerkt richt het informatiesysteem onderwijsarbeidsmarkt zich zowel op de behoefte aan arbeidsmarktinformatie voor studie- en beroepskeuze als op 'degenen die zich beleidsmatig bezighouden met het vraagstuk van de aansluiting van het onderwijs op de arbeidsmarkt: de overheid, de arbeidsvoorzieningsorganisatie, de sociale partners en het onderwijsveld' (ROA, 1992a, blz. i).

Omdat de tweede doelgroep erg divers is samengesteld, wordt in dit evaluatierapport met name gerefereerd aan de eerstgenoemde doelgroep. Dit betekent dat de prognoses en de prognose-opzet steeds tegen het licht van de bruikbaarheid voor studie- en beroepskeuze gehouden worden.

De doelstelling om informatie te genereren die bruikbaar is voor de studie- en beroepskeuzevoorlichting heeft voor deze evaluatie een tweetal consequenties. Ten eerste dient de opzet van het informatiesysteem zodanig te zijn dat de gegenereerde gegevens ondersteuning kunnen geven aan de studie- of beroepskeuzebeslissing van een individuele leerling. Dat wil zeggen dat de informatie:

(1) relevant moet zijn voor de leerlingen;

(2) op individueel niveau betekenis moet hebben;

(3) gepresenteerd wordt op een wijze die voor leerlingen goed interpreteerbaar is.

De eerste voorwaarde, de relevantie voor de leerlingen, betekent dat de prognoses betrekking moeten hebben op aspecten die van belang kunnen zijn voor de studieof beroepskeuzebeslissingen. Dat wil zeggen dat de prognoses inzicht moeten geven in de situatie op de arbeidsmarkt die een leerling aan zal treffen vanaf het moment dat deze, na zijn studie te hebben voltooid, tot de arbeidsmarkt toetreedt. Deze voorwaarde legt dus eisen op aan de periode waarop de prognoses betrekking hebben en aan de groep op de arbeidsmarkt waarvoor ze relevant zijn. De einddatum van de prognoseperiode dient dus te vallen in de tijd dat de schoolverlaters de arbeidsmarkt zullen betreden en de verwachte perspectieven dienen op nieuwkomers op de arbeidsmarkt gebaseerd te zijn.

De tweede voorwaarde betreft de vereiste dimensie van de informatie. Vanuit de studie- en beroepskeuzedoelstelling dienen de prognoses bruikbaar te zijn voor het 
maken van een individuele keuze voor een bepaalde opleiding of beroep. Voor leerlingen die voor een studiekeuze staan, is het relevant te weten welke situatie zij op de arbeidsmarkt aan zullen treffen na afloop van de gekozen opleiding. Bepaalde ontwikkelingen zijn vanuit een algemeen gezichtspunt zeer relevant voor de beschrijving van de arbeidsmarkt, maar zijn voor individuen pas bruikbaar na een vertaling naar het individueel niveau. Zo is de totale werkgelegenheidsgroei voor een bepaalde opleidingscategorie vanuit een beleidsoogpunt interessant, maar is het voor een leerling belangrijker wat zijn of haar individuele kans op een bepaald soort werk na afloop van de studie zal zijn.

De derde voorwaarde voor de opzet van het prognose-systeem om bruikbaar te zijn voor studie- en beroepskeuzevoorlichting is de interpreteerbaarheid van de informatie. Om bruikbaar te zijn voor leerlingen dienen de prognoses geformuleerd te zijn in termen die begrijpelijk zijn voor iemand die niet volledig ingewijd is in de arbeidsmarktproblematiek ${ }^{1}$. De prognoseresultaten dienen zoveel mogelijk geformuleerd te worden in algemeen gehanteerde begrippen en zo min mogelijk statistisch of economisch jargon te bevatten. Met name met betrekking tot statistische uitspraken over de betrouwbaarheid van de prognoses is een vertaling van groot belang. De verbetering van de interpreteerbaarheid van de arbeidsmarktgegevens kan overigens van twee kanten komen. Immers, het kan ook zinvol zijn om, zoals momenteel ook in het kader van de basisvorming wordt beoogd, leerlingen meer inzicht te geven in het functioneren van de arbeidsmarkt, om zo de begrijpelijkheid van de arbeidsmarktinformatie te vergroten. Ook voor intermediairs die betrokken zijn bij de studie- en beroepskeuzevoorlichting is het van belang dat zij inzicht verwerven in het functioneren van de aansluiting tussen onderwijs en de arbeidsmarkt (De Wit, 1996, Teunis, 1996).

Een tweede consequentie van de doelstelling om informatie te genereren die bruikbaar is voor de studie- en beroepskeuze is dat ook de empirische evaluatie zal plaatsvinden vanuit dit gezichtspunt. Dit betekent dat het gehanteerde evaluatiecriterium, waarmee de omvang van de voorspelfouten wordt vastgesteld, vooral moet laten zien welke consequenties deze voorspelfouten hebben voor de individuele studie- en beroepskeuze. De keuze van het evaluatiecriterium wordt besproken in paragraaf 3.3 .

Bij een beoordeling van de prognoses vanuit een andere doelstelling zullen dan mogelijk ook andere eisen gesteld moeten worden aan zowel de inhoud en vorm van de informatie als aan het gehanteerde evaluatiecriterium. In hoofdstuk 2 wordt

1. Mede om een juiste interpretatie van de voorspellingen te bevorderen werden de gegevens van het informatiesysteem overigens niet rechtstreeks aan de leerlingen verstrekt, maar was I-See! primair bedoeld voor schooldecanen en andere intermediairs. 
beargumenteerd dat een evaluatiecriterium vanuit de studie- en beroepskeuzeoptiek gebaseerd dient te zijn op procentuele voorspelfouten, terwijl het vanuit de beleidsoptiek wellicht meer voor de hand ligt om de absolute aantallen in de voorspelfout te gebruiken.

\section{Opzet prognoses}

Figuur 1.1 geeft een schematisch overzicht van de opzet van de prognosemethodiek. In grote lijnen komt deze opzet overeen met de opzet van de prognoses voor 1992 (Zie Dekker e.a., 1992). Aan de vraagkant dienen de werkgelegenheidsprognoses naar bedrijfssector van het Centraal Planbureau (CPB) als externe informatiebron. Deze prognoses hadden destijds betrekking op 14 bedrijfssectoren. Het voorspelde aantal werkzame personen in deze bedrijfssectoren is vervolgens vertaald naar de werkgelegenheid in 93 beroepsklassen. De classificatie die bij het maken van deze prognoses is gehanteerd voor bedrijfssectoren en beroepsklassen wijkt af van de classificaties die zijn gehanteerd bij de prognoses voor de periode 1985-1992. Toen werden 22 bedrijfssectoren en 79 beroepsklassen onderscheiden. De verandering met betrekking tot de bedrijfssectorindeling komt voort uit een vergelijkbare verandering in het model dat het CPB hanteert. De nieuwe beroepenclassificatie is gebaseerd op Dekker, De Grip en Van de Loo (1990). Hierin worden met behulp van een analyse van De Grip, Groot en Heijke (1991) beroepen geclusterd op basis van hun overeenkomst in opleidingenstructuur. Hierdoor werden beroepsklassen gevormd die homogener zijn vanuit de onderwijsinvalshoek.

Vergeleken met de situatie in het basisjaar, 1989, levert deze voorspelde vraag naar beroepen de verwachte uitbreidingsvraag per beroepsklasse op. Hieraan wordt een prognose van de verwachte vervangingsvraag toegevoegd. Te zamen leveren de uitbreidingsvraag en de vervangingsvraag het verwachte aantal baanopeningen op. Verondersteld is dat deze baanopeningen de voor studie- en beroepskeuzedoeleinden relevante grootheid zijn. Nieuwkomers op de arbeidsmarkt kunnen immers niet zonder meer de reeds werkzame personen uit hun baan verdringen. Op grond van het instroomprofiel in het verleden is ook bepaald hoeveel van deze baanopeningen beschikbaar zijn voor schoolverlaters.

Naast deze prognoses van het aantal baanopeningen per beroepsklasse worden in het informatiesysteem ook actuele data en indicatoren per beroepsklasse opgenomen. De actuele data betreffen het aantal werkenden in de betreffende beroepsklasse, het percentage vrouwen, de verdeling van de werkenden over leeftijdsklassen, het percentage werkenden jonger dan 30 jaar, het percentage werkenden met een arbeidsduur minder dan 30 uur per week en de verdeling over de opleidingsniveau. De achterliggende idee is dat dergelijke informatie kan bijdragen aan de 'horizonverbreding' bij de studie- en beroepskeuzevoorlichting en 
op de verschillende punten inzicht geeft in enkele arbeidsmarktrelevante kenmerken van de desbetreffende beroepsklasse.

\section{Figuur 1.1}

De opzet van het prognosemodel van het informatiesysteem onderwijs-arbeidsmarkt 
De indicatoren betreffen de sectorspreiding en de conjunctuurgevoeligheid van de werkgelegenheid. Dat zijn beide zogenaamde risico-indicatoren. De branchespreiding geeft aan in welke mate de werkgelegenheid in deze beroepsklasse gespreid is over verschillende bedrijfssectoren. Als deze spreiding groot is, zal een onverwachte verandering in een bepaalde bedrijfstak relatief weinig invloed hebben op de ontwikkelingen in dat beroep. Verder geeft de branchespreiding ook aan dat, indien er een tegenvallende vraag in een van de bedrijfstakken optreedt, er waarschijnlijk wel mogelijkheden zijn om in andere bedrijfssectoren werk te vinden. De conjunctuurgevoeligheid geeft aan in welke mate de werkgelegenheid van het beroep meefluctueert met de conjunctuurgolven. Een hoge conjunctuurgevoeligheid betekent een grotere kans dat in de latere loopbaan de arbeidsmarktperspectieven op een gegeven moment verslechteren. Het ligt voor de hand te veronderstellen dat deze risico-indicatoren indirect ook een indicatie vormen voor de voorspelkwaliteit van de betreffende categorie. In het vorige evaluatierapport is deze mogelijke relatie onderzocht, maar werd dit verband niet systematisch aangetroffen.

De uitbreidingsvraag per beroep is door middel van een verdeelmodel omgezet naar de uitbreidingsvraag per opleidingstype. De vervangingsvraag per opleidingstype is apart berekend, omdat deze niet uit de vervangingsvraag per beroep kan worden afgeleid. Te zamen vormen de vervangingsvraag en de uitbreidingsvraag de totale vraag naar nieuwkomers met de desbetreffende opleidingsachtergrond.

Naast de vraagprognoses is per opleidingstype op basis van de Skill-prognoses ${ }^{2}$, aangevuld met additionele gegevens over het niet-reguliere onderwijs en het deeltijdonderwijs, een prognose gemaakt van het verwachte aanbod van schoolverlaters op de arbeidsmarkt tussen 1989 en 1994. Aan dit aanbod per opleidingstype zijn verder - in tegenstelling tot de prognoses voor 1992 - de aantallen kortdurig werklozen toegevoegd die aan het begin van de prognoseperiode boven de markt zweven. Verondersteld werd dat alleen degenen die korter dan één jaar werkloos zijn serieuze concurrentie voor de schoolverlaters vormen. Op basis van de vraag- en aanbodprognoses wordt de Indicator Toekomstige Arbeidsmarktperspectieven (ITA) bepaald. De ITA geeft een indicatie van de spanning tussen vraag en aanbod in de beschouwde periode. Omdat er in het gehanteerde model geen rekening wordt gehouden met eventuele aanpassingen van de arbeidsmarkt op deze spanningen tussen vraag en aanbod, moet deze spanningsindicator niet zonder meer beschouwd worden als het verwachte

2. De Skill-onderwijsprognoses die destijds werden gemaakt door het Ministerie van Onderwijs, Cultuur en Wetenschappen gaven een integrale raming van leerlingenaantallen in het regulier voltijdsonderwijs, de aantallen behaalde diploma's en de aantallen schoolverlaters. 
aanbodoverschot of -tekort. Uiteraard zullen zowel de vraag- als de aanbodzijde van de arbeidsmarkt gedeeltelijk inspelen op deze spanningen, zodat bijvoorbeeld een overschot aan nieuwkomers met een bepaalde opleiding niet alleen tot uiting hoeft te komen in een hoge werkloosheid, maar ook kan leiden tot achterblijvende lonen, meer kans op banen buiten het beoogde werkveld of andere verslechteringen van de arbeidsmarktsituatie (Wieling en Borghans, 1995).

Naast de prognose van de toekomstige arbeidsmarktsituatie worden voor de opleidingen, net als bij de beroepen, aanvullende gegevens verstrekt. Allereerst wordt wederom een beeld gegeven van de actuele arbeidsmarktsituatie. Deze informatie heeft betrekking op het aantal werkenden, de werkloosheid (alsmede het aandeel van schoolverlaters in de werkloosheid) en het percentage onderbenutting. Bij de werkloosheid wordt tevens een indicatie van de trendmatige ontwikkeling van de cijfers gegeven. Daarnaast wordt een indicatie gegeven van de beroepenspreiding en de bedrijfssectorspreiding. Net als bij beroepen geven deze spreidingsindicatoren een indruk van de gevoeligheid van de prognoses, maar ook meer in het algemeen wordt op deze wijze aangegeven in hoeverre men met het kiezen voor een bepaalde opleiding afhankelijk is van de arbeidsmarktsituatie voor een bepaalde beroepsklasse of een bepaalde bedrijfssector.

Ten behoeve van de studie- en beroepskeuzevoorlichting worden de kwantitatieve gegevens van de prognoses, actuele data en indicatoren getransformeerd naar kwalitatieve typeringen. Op basis van de waargenomen waarden van de variabelen is telkens een classificatie gemaakt op basis van een vijf-punts-schaal. Hieraan is een typering gekoppeld: 'erg laag', 'laag', 'gemiddeld', 'hoog' of 'erg hoog'3. De bedoeling van deze kwalititatieve typeringen is om de kwantitatieve cijfers van de prognoses, indicatoren en actuele data beter toegankelijk te maken voor mensen die niet gewend zijn met dergelijke cijfers te werken. Ten eerste hoeft men zich nu niet te verdiepen in de meeteenheid van de variabele. Ten tweede krijgt men meteen een relatieve typering, zodat men geen inzicht hoeft te hebben in de spreiding van de variabele. Ten derde zorgt de verdeling in intervallen voor een typering die minder exact overkomt dan de cijfers zelf. Hiermee wordt de suggestie van nauwkeurigheid tot achter de komma vermeden en krijgen met name de arbeidsmarktprognoses een zekere bandbreedte.

\subsection{Opzet van het rapport}

Het vervolg van dit rapport is als volgt opgebouwd. Allereerst wordt in hoofdstuk 2 de

3. Voor de ITA is een afwijkende typering gebruikt die varieert van 'goed', 'redelijk', 'matig', tot 'slecht'. 
evaluatiesystematiek besproken. In de daaropvolgende hoofdstukken wordt voor de verschillende onderdelen van het prognosemodel van het informatiesysteem ingegaan op de wijze waarop de prognoses tot stand zijn gekomen en worden deze prognoses vervolgens, voor zover mogelijk, empirisch geëvalueerd. De kwaliteit van de prognoses zal daarbij steeds worden vergeleken met de kwaliteit van de eerder gemaakte prognoses die betrekking hadden op de periode 1985-1992. In hoofdstuk 3 komt de uitbreidingsvraag aan de orde, in hoofdstuk 4 de vervangingsvraag, in hoofdstuk 5 de baanopeningen, in hoofdstuk 6 de instroom van schoolverlaters en in hoofdstuk 7 de confrontatie van vraag en aanbod. In hoofdstuk $8 \mathrm{zal}$, in aanvulling hierop, de kwaliteit van de uitbreidingsvraagprognoses per beroepsklasse uit het informatiesysteem worden vergeleken met de kwaliteit van arbeidsmarktprognoses die door het Bureau of Labor Statistics (BLS) zijn opgesteld voor de Verenigde Staten. Ten slotte worden in hoofdstuk 9 de belangrijkste bevindingen kort samengevat en wordt aangegeven welke aandachtspunten er uit deze evaluatiestudie volgen voor de verdere ontwikkeling van het informatiesysteem. 


\section{Een methode voor de empirische evaluatie}

\subsection{Inleiding}

In het vorige hoofdstuk is de opzet van het informatiesysteem aan de orde gekomen. De prognoses zoals die destijds gemaakt zijn voor de onderdelen van dit systeem zullen in de volgende hoofdstukken worden besproken en voorzover mogelijk, worden onderworpen aan een empirische evaluatie. De methode van evalueren komt vrijwel overeen met de methode die is gehanteerd in het vorige evaluatierapport (Borghans, Van Eijs en De Grip, 1994). Voor zover er veranderingen zijn aangebracht is zorgvuldig nagegaan of deze veranderingen de resultaten substantieel beïnvloeden. Indien dit het geval is wordt hierop expliciet ingegaan. Het uitgangspunt voor deze methode vormen de vragen die volgens Granger en Newbold (1986) een objectieve evaluatie moet beantwoorden:

(1) Zijn de voorspellingen beter dan de beschikbare alternatieven?

(2) Hoe 'goed' zijn de voorspellingen?

(3) Kan de methode waarmee de voorspellingen zijn opgesteld zodanig aangepast worden dat een verbeterde voorspelkwaliteit verwacht mag worden?

In dit hoofdstuk komen alle onderdelen van de evaluatie nog eens kort aan de orde. Allereerst wordt in paragraaf 2.2 het gehanteerde evaluatiecriterium besproken. Dit criterium geeft met name een waardering van het 'verlies' dat ontstaat door de voorspelfouten. Om meer zicht te krijgen op de oorzaken van de voorspelfouten worden vervolgens in paragraaf 2.3 enkele toetsen besproken. $\mathrm{Er}$ wordt achtereenvolgens ingegaan op de concentratie van voorspelfouten, de verklaring van de standaardafwijking van de voorspelfouten en de over- en onderschatting van veranderingen. In paragraaf 2.4 wordt ingegaan op de evaluatie van kwalitatieve typeringen. Ten slotte wordt in paragraaf 2.5 in aanvulling op de methodiek die in het vorige evaluatierapport is ontwikkeld, ingegaan op een methode om de kwaliteit van prognoses te vergelijken met de kwaliteit van eerdere prognoses of soortgelijke prognoses van andere instituten.

\subsection{Het evaluatiecriterium}

Uitgangspunt bij de beoordeling van de prognoses van het informatiesysteem onderwijs-arbeidsmarkt is, zoals gezegd, de doelstelling dat de prognoses geschikt moeten zijn voor de studie- en beroepskeuze. Zowel de voorspellingen van de ontwikkelingen aan de vraagzijde van de arbeidsmarkt als de prognoses van de arbeidsmarktinstroom zijn geformuleerd in aantallen personen. Voor een individuele student is echter niet het totale aantal werkzame personen in een beroep of een opleiding, of de absolute voorspelfout interessant, maar gaat het vooral om de relatieve voorspelfout: $\left(x_{i}-\hat{x}_{i}\right) / y_{i}$, waarin $x_{i}$ staat voor de realisatie van een voorspelde grootheid voor beroep of opleiding $i$, en $\hat{x}_{i}$ de prognose voor dezelfde 
grootheid aanduidt. $y_{i}$ geeft het aantal werkzame personen in de voorspelde categorie aan ${ }^{4}$.

Onder de veronderstelling dat deze relatieve maatstaf normaal verdeeld is, is het zinvol om het kwadraat hiervan als verlies van de afzonderlijke prognose te beschouwen (Granger en Newbold, 1986).

$V_{i}\left(\hat{x}_{i}\right)=\left(\frac{x_{i}-\hat{x}_{i}}{Y_{i}}\right)^{2}$

Het individuele verliescriterium $V_{i}$ geeft dus bij benadering het verlies dat relevant is voor de keuze van een individuele leerling, die eventueel het desbetreffende beroep of de desbetreffende opleiding zal kiezen. In dit rapport zal voor alle prognoseonderdelen een tabel gepresenteerd worden, waarin prognoses, realisatie, voorspelfout en dit gemiddeld verlies per bedrijfssector, beroepsklasse of opleidingstype wordt gegeven. Hoewel een dergelijke overzicht een eerste indruk van de kwaliteit van de voorspellingen geeft en daardoor mogelijke problemen bij de prognoses aan het licht kan brengen, moet bij de interpretatie van dit overzicht gewaakt worden voor ad hoc redeneringen.

Om een beeld te kunnen krijgen van de kwaliteit van bepaalde vraag- of aanbodprognoses, is het niet zo zinvol de prognoses voor iedere bedrijfs-, beroepsof opleidingscategorie afzonderlijk in beschouwing te nemen, omdat veel voorspelfouten op zich een incidenteel karakter hebben. Het is moeilijk hieruit lessen te trekken. Doordat in het ROA-informatiesysteem toentertijd prognoses zijn gemaakt voor 93 beroepsklassen en 53 opleidingstypen is het echter gezien de hoeveelheid informatie ook wenselijk afzonderlijke prognosefouten te aggregeren. Op deze wijze kan beter gekeken worden naar de systematiek in de prognosefouten. Deze aggregatie maakt het mogelijk uitspraken te doen over de kansverdeling van de voorspelfouten, in plaats van een afzonderlijke beschouwing van iedere voorspelling te maken. De voorspelfouten kunnen worden geaggregeerd door op basis van het individuele verlies, $v_{i}$, het gemiddelde verlies te berekenen.

Bij het aggregeren van dit criterium moet er rekening mee worden gehouden dat er veel meer nieuwkomers op de arbeidsmarkt in een groot beroep of een grote opleidingscategorie terecht komen dan in een kleine. Door te wegen naar de omvang van het beroep of de opleidingscategorie wordt het gemiddeld verlies

4. Bij de evaluatie van de uitbreidingsvraag geldt daarom dat $x_{i}=y_{i}$. 
bepaald. Dit is het evaluatiecriterium op geaggregeerd niveau:

$$
G V(\hat{x})=\sum_{i} \frac{y_{i}}{y^{\text {tot }}} V_{i}\left(\hat{x}_{i}\right)=\sum_{i} \frac{y_{i}}{y^{\text {tot }}}\left(\frac{x_{i}-\hat{x}_{i}}{y_{i}}\right)^{2}=\sum_{i} \frac{1}{y^{\text {tot }}} \frac{\left(x_{i}-\hat{x}_{i}\right)^{2}}{y_{i}}
$$

Hierin is $y^{\text {tot }}=\sum_{i} y_{i}$ de totale gerealiseerde omvang van de werkzame personen, terwijl het gemiddeld verlies (GV) het verlies van een gemiddelde leerling aangeeft.

De verliesfunctie geeft een schatting van de spreiding van de voorspellingen rond de realisatie en daarmee een antwoord op de tweede eis die Granger en Newbold (1986) stellen aan een objectieve evaluatie. Op grond van dit cijfer is het echter niet mogelijk een duidelijke uitspraak te doen over de kwaliteit van de prognoses. Er is immers geen informatie beschikbaar over wat een redelijke waarde voor het gemiddeld verlies zou zijn. Om te voorzien in een dergelijke beoordelingsmaatstaf kan de destijds gehanteerde prognose vergeleken worden met de voorspelkwaliteit van andere beschikbare prognoses, conform de eerste eis uit de lijst van Granger en Newbold. Door de verhouding te nemen tussen de voorspelkwaliteit van de prognose en de voorspelkwaliteit van een referentievoorspelling, ontstaat een score die kleiner is dan 1 als de prognose beter is dan de referentieprognose en groter dan 1 als de prognose slechter is:

$S\left(\hat{x}, x^{r e f}\right)=\frac{G V(\hat{x})}{G V\left(x^{r e f}\right)}$

Om invulling te kunnen geven aan de score-definitie, moet een bepaalde prognose als referentieprognose worden bestempeld. Evenals bij de vorige evaluatie van de ROA-prognoses (Borghans, Van Eijs en De Grip, 1994) worden de prognoses daarbij vergeleken met de beschikbare arbeidsmarktinformatie in de situatie waarin leerlingen die voor een bepaalde studiekeuzebeslissing staan zouden verkeren indien ze geen prognoses uit het informatiesysteem tot hun beschikking zouden hebben. Verondersteld wordt dat leerlingen in dat geval hun keuze zouden baseren op de huidige arbeidsmarktsituatie. Daarom wordt de situatie in het basisjaar als referentieprognose gehanteerd. Deze Same As Before prognose (SAB) veronderstelt dat er tussen het basisjaar en het prognosejaar geen veranderingen zullen optreden. In sommige gevallen is de Same As Before prognose echter niet zo zinvol als referentie. Dit is bijvoorbeeld het geval bij de vervangingsvraag. Het is immers niet aannemelijk dat leerlingen op de hoogte zijn van de omvang van de vervangingsvraag op dat moment. In dit geval is het meer plausibel om de gemiddelde voorspelde vervangingsvraag als percentage van het aantal werkzame personen te gebruiken als een referentieprognose voor de vervangingsvraag per beroep of opleiding. 
Om de invloed van een afzonderlijke beroepsklasse of opleidingstype op de score vast te stellen is ook de marginale bijdrage aan de score vastgesteld. Omdat de voorspelfout van de referentieprognose bij toeval mogelijk zeer klein of zelfs 0 kan zijn, heeft het geen zin de score per afzonderlijke categorie vast te stellen. De marginale score is daarom vastgesteld als het verschil tussen de feitelijke score en de score die resulteert als de betreffende categorie niet wordt meegenomen bij de berekening. Deze marginale score is niet in de tabellen opgenomen. Wel wordt in de tekst gewezen op uitzonderlijke hoge positieve en negatieve marginale scores.

Een laatste punt van afweging is de schaal waarop de prognoses geëvalueerd worden. In het kader van de studie- en beroepskeuzevoorlichting gaat het er niet alleen om een goede inschatting te maken van de absolute positie van een beroep of opleiding, maar vooral ook om het in beeld brengen van de relatieve positie. Daarom wordt de evaluatie in dit rapport doorgaans naast de absolute prognoses ook uitgevoerd op een prognose die gecorrigeerd is voor het totale volume-effect. Dat wil zeggen, de prognoses zijn vermenigvuldigd met een factor zodanig dat over alle categorieën geaggregeerd de prognoses gelijk zijn aan de realisatie. Deze prognoses worden aangeduid als de relatieve prognoses.

\subsection{De oorzaak van voorspelfouten}

Het gemiddeld verlies en de score die in de vorige paragraaf zijn besproken, geven informatie over de kwaliteit van de gemaakte voorspellingen. Op zich geven zij echter niet aan waardoor een prognose goed of slecht is uitgevallen. Op deze wijze wordt derhalve niet duidelijk hoe de prognosemethodiek op grond van de evaluatieresultaten kan worden aangepast. Dit laatste is volgens Granger en Newbold (1986) het derde belangrijke punt bij het uitvoeren van een objectieve evaluatie. Om op basis van deze evaluatie conclusies te kunnen trekken die inzicht geven in de aard van de problemen die bij de prognoses verwacht kunnen worden en om consequenties met betrekking tot de gehanteerde methodiek te kunnen trekken, worden in aanvulling op de in de vorige paragraaf beschreven evaluatiemaatstaf, enkele analyses uitgevoerd die inzicht verschaffen in de oorzaken van de gemaakte voorspelfouten.

\section{Concentratie van voorspelfouten}

De evaluatiemaatstaf uit de vorige paragraaf geeft aan wat de gemiddelde voorspelfout van alle beroepen of alle opleidingen is. Om inzicht te krijgen in de oorzaken van deze voorspelfouten zal gekeken worden naar de voorspelfout in bepaalde soorten bedrijfssectoren, beroepsklassen of opleidingstypen. Er zijn twee soorten indelingen die in dit rapport worden gehanteerd. Ten eerste kan gekeken worden naar de voorspelkwaliteit van iedere bedrijfssector, opleiding of beroep 
afzonderlijk. Een nadeel van deze aanpak is, zoals reeds is opgemerkt, dat op deze wijze het systematische karakter van voorspelfouten niet meer aan het licht kan komen. ledere voorspelfout wordt in dat geval als een incident op zich beschouwd waardoor de structuur achter deze voorspelfouten verloren gaat. Op het moment dat de prognose wordt gemaakt is immers - op zijn minst vanuit het gezichtspunt van de voorspeller - onvoorspelbaar hoe groot de voorspelfout zal zijn. Voor evaluatiedoeleinden is het interessant inzicht te hebben in de verdeling die deze toevalsvariabele heeft. In de empirische evaluatie in de komende hoofdstukken zal hiervan een schatting worden gemaakt. Uitgangspunt hierbij is dat de voorspelfouten $\left(\epsilon_{i}\right)$ normaal verdeeld zijn:

$\epsilon_{i}=x_{i}-\hat{x}_{i} \sim N\left(\mu_{i}, \sigma_{i}^{2}\right)$

met:

$\sigma_{i}=\left(y_{i}\right)^{\alpha} e^{z_{i} \beta}$

$\mu_{i}=\theta\left(\hat{x}_{i}-x_{i}^{r e f}\right)$

Hierin is $x_{i}$ wederom de te voorspellen grootheid (bijvoorbeeld de uitbreidingsvraag per beroepsklasse of opleidingstype) in het prognosejaar, $\hat{x}_{i}$ de prognose van deze grootheid, $x_{i}{ }^{\text {ref }}$ de al eerder genoemde referentieprognose, waarbij geen veranderingen verwacht worden en $Z_{i}$ zijn de andere verklarende variabelen voor de standaardafwijking van de prognoses. De variabele $y_{i}$ duidt de omvang van het betreffende opleidingstype of de betreffende beroepsklasse aan. Bij prognoses van de werkgelegenheid geldt dus dat $y_{i}=x_{i}, \sigma_{i}$ is een parameter voor de standaardafwijking van de voorspelfout, terwijl $\mu_{i}$ de verwachte waarde van de te voorspellen grootheid is als er wordt gecorrigeerd voor een systematische over- of onderschatting van veranderingen. Op beide aspecten wordt hierna verder ingegaan. De schatting van (4), (5) en (6) vindt plaats met behulp van de maximum-likelihoodmethode.

\section{Verklaring van de standaardafwijking}

Als eerste wordt met vergelijking (4) - (6) onderzocht of er verklarende variabelen zijn voor de standaardafwijking van de voorspelfout. De eerste factor in vergelijking (5), de grootte van het beroep of de opleidingscategorie $y_{i}$, is opgenomen om het schaal-effect te kunnen vaststellen. Er kan verwacht worden dat grotere beroepsklassen of opleidingstypen ook te maken hebben met grotere voorspelfouten, maar 
waarschijnlijk zal deze voorspelfout niet volledig proportioneel toenemen. $\alpha$ zal dus waarschijnlijk kleiner zijn dan 1 en groter dan 0 . De keuze van de overige verklarende variabelen voor de omvang van de standaarddeviatie van de voorspelfouten $\left(Z_{i}\right)$ hangt af van de grootheid die in beschouwing wordt genomen. Vergelijkbaar met de in de vorige paragraaf gemaakte indeling kan hierbij zowel gedacht worden aan inhoudelijke variabelen als aan variabelen die te maken hebben met de gehanteerde methodiek.

Het informatiesysteem onderwijs-arbeidsmarkt bevat, zoals reeds eerder is aangegeven, ook zogenaamde risico-indicatoren. Deze indicatoren zijn mede bedoeld om een beeld te geven van de gevoeligheid van een bepaalde beroepsklasse of een opleidingstype voor exogene invloeden. Er kan dus verwacht worden dat er een samenhang bestaat tussen deze risico-indicatoren en de omvang van de voorspelfout. De methode op basis van (4) en (5) kan daardoor ook gebruikt worden om deze risico-indicatoren indirect te evalueren.

De vorm van (5) is gekozen om te verzekeren dat de standaardfout altijd positief is. Overigens wordt in Borghans, Van Eijs en De Grip (1994) vergelijking (5) geschat onder de restrictie dat $\mu_{i}=0$. Dit heeft alleen invloed op de schattingen voor $\alpha$ en $\beta$ als $x_{i}, z_{i}$ en $\left(\hat{x}_{i}-x_{i}{ }^{\text {ref }}\right)$ gecorreleerd zijn. Als hierdoor de resultaten substantieel afwijken van de resultaten die op basis van de oude methodiek verkregen zouden zijn zal dat expliciet opgemerkt worden.

\section{Over- of onderschatting van veranderingen}

Vergelijking (6) geeft een indicatie van de mate waarin er over- of onderschatting van de veranderingen heeft plaatsgevonden. Een belangrijke component in de prognoses is veelal de trend in de te voorspellen grootheid. Een cruciaal punt bij het extrapoleren van bestaande trends is de wijze waarop deze extrapolatie plaats dient te vinden. Het zonder meer doortrekken van trends leidt vaak, zeker op de langere termijn, tot onwaarschijnlijke resultaten. In dat geval wordt soms de trend helemaal niet opgenomen in de prognose, of wordt er een aanpak gekozen waarbij de invloed van de trend afneemt in de loop van de tijd. Vergelijkbare problemen doen zich in principe voor bij iedere verklarende variabele. Als een schatting van een parameter toevallig hoog uitvalt, zal men, wanneer de prognose op deze hoge parameterwaarde wordt gebaseerd, de invloed van deze variabele overschatten. Derhalve wordt er vaak bij niet significante waardes van de parameterschatting gekozen voor het negeren van de parameter bij het opstellen van de prognose.

Een evaluatie is een geschikt middel om te bekijken in hoeverre de geschatte invloeden van de exogene variabelen in het verleden op een juiste manier zijn doorgetrokken naar de toekomst. Een te voorzichtige extrapolatie staat - ongeacht 
of het gaat om een positieve of een negatieve trend - bekend als een onderschatting van verandering, terwijl een overdreven extrapolatie een overschatting van verandering is (zie Theil, 1958, en Borghans, 1993). Op basis van deze vergelijking is het mogelijk een verwachting van het verschil tussen de realisatie en de prognose te formuleren. De rechterkant van vergelijking (6) bevat alleen grootheden die bekend waren op het moment dat de prognose werd opgesteld. Daardoor zou het destijds in principe mogelijk zijn geweest een betere prognose op te stellen die deze over- of onderschatting van veranderingen niet bevatte. Figuur 3.1 geeft aan wat de betekenis is van bepaalde parameterwaarden van $\theta$. In de figuur is verondersteld dat de prognose hoger uitvalt dan de waarde van de grootheid in het basisjaar. Het omgekeerde is echter ook mogelijk. Dan ontstaat een situatie die het spiegelbeeld is van de in figuur 3.1 geschetste situatie.

\section{Figuur 2.1}

De mogelijke waarden van de overschattingscoëfficiënt $\theta$ bij een over- of onderschatting van veranderingen

In de figuur zijn drie gebieden te onderscheiden met twee grenswaarden. Als $\theta=0$ dan is gemiddeld genomen de realisatie gelijk aan de prognose. De kwaliteit van de prognose kan dan weliswaar nog slecht zijn, maar er vindt geen systematische over- of onderschatting van de veranderingen plaats. Als $\theta>0$ dan ligt de realisatie van de voorspelde grootheid gemiddeld verder van de waarde in het basisjaar af dan de prognose. $\mathrm{Er}$ is dan dus een onderschatting van veranderingen. 
Omgekeerd betekent $\theta<0$ dat de realisatie gemiddeld dichter bij de waarde in het basisjaar ligt dan de prognose. Er is dan dus sprake van een overschatting van veranderingen. Hierbij wordt verondersteld dat $\theta>-1$. Als $\theta=-1$ dan is de overschatting van de veranderingen totaal. Dat wil zeggen dat in dat geval iedere voorspelde verandering geen enkele informatieve waarde had en men net zo goed de referentieprognose als prognose had kunnen hanteren. Als $\theta$ kleiner is dan -1 , dan is er zelfs sprake van een omkeringseffect. Dit betekent dat daar waar dalingen werden voorspeld er gemiddeld sprake was van een stijging, terwijl er bij voorspellingen van stijgingen gemiddeld een daling is opgetreden.

Een over- of onderschatting van veranderingen kan veroorzaakt worden een te hoge of te lage gemiddelde prognose. Als relatieve prognoses worden geanalyseerd speelt dit echter geen rol meer. In dat geval betekent een overschatting van veranderingen dat voorspelde groei gemiddeld lager uitviel dat verwacht, terwijl tegelijkertijd ook de voorspelde krimp minder negatief uitviel dan voorzien.

Een overschatting van veranderingen hoeft niet alleen veroorzaakt te zijn door het te ver doortrekken van trends, maar is vaak het gevolg van een grote storingscomponent in de prognoses. Als prognoses naast een informatief gedeelte ook ruis bevatten kan het zinvol zijn de voorspelde veranderingen gedeeltelijk te negeren. Dergelijke ruis wordt doorgaans veroorzaakt door meetfouten in de gebruikte data, bijvoorbeeld vanwege de steekproeffout. Des te groter deze storingscomponent des te voorzichtiger men zou moeten zijn met het hanteren van de prognoses. In vergelijking (6) wordt dit aangegeven door een waarde van $\theta$ die dicht bij -1 ligt.

\subsection{De evaluatie van kwalitatieve typeringen}

De geschetste evaluatiemethode had tot nog toe betrekking op de puntvoorspellingen die voortkomen uit de prognosemodellen van het informatiesysteem. De uiteindelijke presentatie van de prognoses heeft echter plaatsgevonden door middel van een kwalitatieve typering van de prognoseresultaten.

In het vorige evaluatierapport is uitgebreid ingegaan op de evaluatie van de kwalitatieve typeringen van de voorspelde arbeidsmarktontwikkelingen. Hierbij werd de relatie tussen de voorspelkwaliteit en de trefkans bij de kwalitatieve typering verklaard door de breedte van het gehanteerde interval en de toevallige positie van de prognoses binnen dit interval. In deze evaluatiestudie zal deze analyse niet worden herhaald, omdat niet verwacht wordt dat dit tot andere conclusies zal leiden. Er zal daarom worden volstaan met een directe manier om deze kwalitatieve typeringen te evalueren. Dit houdt in dat de ontwikkelingen die feitelijk hebben plaatsgevonden volgens hetzelfde indelingsschema worden voorzien van een kwalitatieve typering, waarna kan worden nagegaan in hoeveel gevallen de 
oorspronkelijke typering overeenkomt met deze realisatie (zie ook De Grip, Heijke en Berendsen, 1991). Een dergelijke evaluatie wordt gemaakt op basis van een matrix waarbij de oorspronkelijke typering en de realisatie tegen elkaar worden afgezet. In dit rapport wordt hierbij steeds uitgegaan van de relatieve prognoses. Opgemerkt dient echter te worden dat bij een dergelijke evaluatie gelijktijdig de voorspelkwaliteit van de prognoses als de wijze van typeren wordt geëvalueerd. In het vorige evaluatierapport werd getoond dat als relatief slechte prognoses getypeerd worden in kwalificaties die een breed interval vertegenwoordigen, deze kwalitatieve typeringen toch heel bevredigend kunnen zijn geweest. Omgekeerd zullen zeer nauwkeurige prognoses vaak een onjuiste typering krijgen als de kwalificaties gebaseerd zijn op extreem smalle intervallen.

\subsection{Vergelijken met ander prognoses}

Bij het evalueren van prognoses is het van belang om de kwaliteit van de prognoses te vergelijken met andere prognoses met betrekking tot de desbetreffende bedrijfssector, beroep of opleiding. Het kan dan gaan om eerder gemaakte prognoses, of om prognoses die zijn gemaakt in een andere context, bijvoorbeeld door buitenlandse prognose-instituten. In het eerste geval wordt duidelijk of de aangebrachte verbeteringen in het prognosemodel ook tot een betere kwaliteit van de prognoses hebben geleid. In het tweede geval kan worden geanalyseerd op welke punten andere prognosemodellen het beter doen. In OECD (1994) wordt een dergelijke vergelijking tussen de 'manpower forecasts' in diverse landen gemaakt. Een directe vergelijking is echter veelal niet goed mogelijk, omdat de omstandigheden waaronder de prognoses worden gemaakt sterk kunnen verschillen. $\mathrm{Er}$ kunnen verschillen bestaan tussen de gehanteerde classificaties, de voorspelperiode, de kwaliteit van de beschikbare data en verder kan de mate waarin veranderingen op de arbeidsmarkt optreden in de verschillende landen variëren.

De meeste van deze verstorende invloeden bij het vergelijken van prognoses, zijn echter in gelijke mate van invloed op de referentieprognose. Het lijkt daarom zinvol prognoses onderling te vergelijken op basis van de in vergelijking (2) geformuleerde score-maatstaf. Aangezien verwacht wordt dat de schaal van de te voorspellen grootheid invloed heeft op de nauwkeurigheid van de voorspellingen, moet hierbij ook rekening worden gehouden met de invloed van de gehanteerde classificatie.

Dit kan worden verduidelijkt met behulp van figuur 2.2. Verondersteld is dat de voorspelfouten normaal verdeeld zijn zoals in vergelijking (4). Als de schaal de enige verklarende variabele zou zijn voor de standaardfout van de voorspellingen, kan de standaarddeviatie worden afgezet tegen de omvang van de werkgelegenheid van de betreffende categorie. Figuur 2.2 geeft de standaarddeviatie van de voorspelfouten als functie van de schaal. Verschillen in voorspelkwaliteit tussen prognoses kunnen 
twee oorzaken hebben. Als de beroepen van de classificatie die op tijdstip 1 werd gehanteerd zich in gebied $A$ bevinden en de beroepen van de classificatie op tijdstip 2 in gebied $B$ dan wordt het verschil alleen veroorzaakt door schaalverschillen. De kwaliteit van de prognoses bij een gegeven schaal is dus voor beide tijdstippen gelijk. Het is echter ook mogelijk dat de voorspelkwaliteit op tijdstip 2 lager is, dat wil zeggen dat de curve $C C$ is verschoven naar $C^{\prime} C^{\prime}$.

Figuur 2.2

Een vergelijking tussen twee verschillende prognoses

De curve CC kan echter ook verschuiven om redenen waar de onderzoeker geen invloed op heeft, bijvoorbeeld een slechtere kwaliteit van de data waarop de prognoses zijn gebaseerd, minder nauwkeurige cijfers bij de evaluatie, een langere prognosetermijn of ook een prognosesperiode waarin relatief veel verschuivingen plaatsvonden. Het is daarom, zoals reeds opgemerkt, beter om de kwaliteit van de prognoses af te zetten tegen de kwaliteit van de referentieprognose. Er wordt verondersteld dat de standaardfout van de referentieprognose een zelfde functionele vorm heeft als $(5)^{5}$ :

$\sigma_{i}^{r e f}=\left(y_{i}\right)^{\alpha^{r e t}} e^{\beta^{r e t}}$

5. Uit vergelijking (6) volgt dat de voorspelfout van de referentieprognose per definitie een verwachting 0 heeft. 
Hieruit volgt:

$\sigma_{i}^{p r} / \sigma_{i}^{r e f}=\left(y_{i}\right)^{\alpha p r-\alpha^{r e f}} e^{\beta p r-\beta^{r o t}}$

Waar $p r$ staat voor de prognose. Vergelijking (8) geeft dus de nauwkeurigheid van de prognose ten opzichte van de referentieprognose. Door (8) te vergelijken voor verschillende prognoses wordt duidelijk of verschillen in voorspelkwaliteit worden veroorzaakt door classificatieverschillen of door verschillen in de gehanteerde prognosemodellen. 



\section{De uitbreidingsvraag}

\subsection{Inleiding}

Als eerste onderdeel van de arbeidsmarktprognoses komt in dit hoofdstuk de uitbreidingsvraag aan bod. Hoewel de uitbreidingsvraag doorgaans slechts een beperkt onderdeel uitmaakt van het totale aantal baanopeningen, zijn deze prognoses belangrijk omdat de uitbreidingsvraag veel sterker varieert tussen de beroepsklassen en opleidingstypen dan de vervangingsvraag. Uit de vorige evaluatiestudie blijkt dan ook dat de uitbreidingsvraag de minst goed voorspelbare component is. In dit hoofdstuk wordt allereerst in paragraaf 3.2 de gehanteerde methodiek besproken die ten grondslag lag aan de prognoses voor de periode 19891994. Deze methode is beschreven in Dekker e.a. (1992). Peeters (1990) gaat specifiek in op het toegepaste modified multinomial logit model (MML). Vervolgens worden de prognoses in paragraaf 3.3 empirisch geëvalueerd.

\subsection{Prognoses uitbreidingsvraag}

Uitgangspunt voor de uitbreidingsvraagprognoses zijn de werkgelegenheidsprognoses per bedrijfssector van het Centraal Planbureau (CPB) voor de periode 19891994. De werkgelegenheidsprognoses per bedrijfssector zijn omgezet in werkgelegenheidsprognoses per beroepssegment en vervolgens per beroepsklasse. Op basis van de voorspelde uitbreidingsvraag per beroepssegment is daarna de uitbreidingsvraag per opleidingstype bepaald.

\section{Bedrijfssectorprognoses}

De sectorale werkgelegenheidsprognoses van het CBP zijn gemeten in arbeidsjaren. Op basis van de door het CPB voorspelde ontwikkelingen van de P/A-ratio's per bedrijfstak - die de verhouding tussen personen en arbeidsjaren aangeven - is de werkgelegenheid in personen per sector berekend. De werkgelegenheid per bedrijfstak in 1989 volgens het CPB, is gebaseerd op de nationale rekeningen. Deze cijfers komen echter niet exact overeen met het aantal werkzame personen volgens de Enquête Beroepsbevolking (EBB), die de basis vormt voor de analyse van de werkgelegenheidsontwikkeling naar beroepsklasse en opleidingstype. Discrepanties tussen de EBB en de Nationale rekeningen komen onder andere voort uit een andere indeling van sommige economische activiteiten, bijvoorbeeld voor uitzendkrachten en schoonmaakpersoneel en het feit dat in de EBB-cijfers een aanzienlijk deel van werkenden de bedrijfssector niet bekend is. Bovendien is er in de EBB sprake van een aanzienlijke toename van het aantal werkzame personen, als gevolg van veranderingen in de enquête ten opzichte van de voorganger de AKT, waardoor een groter aantal deeltijdwerkers tot de beroepsbevolking werden 
gerekend dan voorheen het geval was. Door deze discrepanties konden de CPBprognoses niet direct gebruikt worden als basis voor de uitbreidingsvraagprognoses naar beroepsklassen. Op basis van de CPB-prognoses zijn daarom aangepaste bedrijfssectorprognoses opgesteld waarbij de AKT/EBB-reeks 1979-1989 als uitgangspunt is genomen. De EBB-cijfers zijn daarbij gecorrigeerd voor de toename van het aantal werkenden als gevolg van een definitieverschil met betrekking tot de beroepsbevolking tussen AKT en EBB. Dat betekent dus dat er feitelijk is gewerkt met prognosecijfers voor 1989 in plaats van realisaties.

Bij de eerdere prognoses voor 1992 zijn de CPB-prognoses niet aangepast. De procentuele groeicijfers per sector volgens het CPB zijn toen opgelegd aan aantallen werkzame personen per sector volgens de AKT. Uit de evaluatie van genoemde prognoses voor 1992 is gebleken dat de discrepantie tussen AKT en EBB geen significante invloed had op de voorspelfouten van de bedrijfssectorprognoses. De gemaakte aanpassingen bleken derhalve achteraf minder relevant. Bij de arbeidsmarktprognoses die later zijn opgesteld zijn de CPB-bedrijfssectorprognoses overigens ook niet meer aangepast. De discrepanties tussen AKT en EBB zijn met name terug te vinden bij de kleine banen van minder dan 12 uur per week. Inmiddels is de definitie van de werkzame personen door het CBS aangepast. Thans worden alleen personen die minstens 12 uur per week werken meegerekend, zodat deze aansluitingsproblemen grotendeels verdwenen zijn.

\section{Beroepenmodel}

In het beroepenmodel worden de werkgelegenheidsprognoses per bedrijfssector omgezet in werkgelegenheidsprognoses per beroepsklasse. Het gaat hier overigens om een andere beroepsklassenindeling dan de indeling die is gehanteerd voor de prognoses tot 1992 (zie De Grip, Heijke en Dekker, 1989). De beroepsklasseindeling van het $C B S$ is vervangen door de in de jaren daarvoor ontwikkelde ROAclassificatie (zie De Grip, Groot en Heijke, 1991 en Dekker, De Grip en Van de Loo, 1990). Bij de classificatie zijn beroepen geclusterd op basis van overeenkomst in de opleidingenstructuur van beroepen. Deze nieuwe classificatie is opgesteld omdat een dergelijke indeling beter geschikt is voor het analyseren van de aansluiting tussen onderwijs en arbeidsmarkt. De omzetting van de werkgelegenheidsprognoses van bedrijfssector naar beroepsklasse gebeurt in twee stappen. In de eerste stap wordt de werkgelegenheid per beroepssegment bepaald. De ROA-beroepenclassificatie onderscheidt 48 beroepssegmenten. In de tweede stap is vervolgens de werkgelegenheid per beroepssegment verbijzonderd naar de werkgelegenheid per beroepsklasse. Er worden 93 beroepsklassen onderscheiden. In een aantal gevallen bevat een beroepssegement slechts één beroepsklasse en is deze tweede stap dus niet nodig. De meeste beroepssegmenten bevatten echter meerdere beroepsklassen. 
Door eerst de werkgelegenheid per beroepssegment te bepalen wordt minder hinder ondervonden van de door het CBS gehanteerde ondergrens bij het gebruik van EBB-data van 2.500. De werkgelegenheid per beroepssegment werd vastgesteld per bedrijfssector. Bij de verbijzondering naar beroepsklasse werden de over de bedrijfssectoren geaggregeerde cijfers gehanteerd.

De verwachte werkgelegenheidsontwikkelingen per beroepssegment zijn niet alleen afhankelijk van de verwachte sectorale werkgelegenheidsontwikkelingen, maar ook van de veranderingen in de beroepenstructuur per bedrijfssector. Daarom moeten ook de veranderingen in de beroepenstructuur voorspeld worden. Dit is gebeurd met een modified multinomial logit model (zie Dekker e.a., 1992 en Peeters, 1990). Dit model werd voor het eerst gebruikt. Eerder werd gebruik gemaakt van het model van Dekker, De Grip en Heijke (1990). In dit model wordt het logaritme van het aandeel van een beroepssegment in de totale werkgelegenheid in de sector ten opzichte van het werkgelegenheidsaandeel van een referentieberoep als afhankelijke variabele genomen. Dit model heeft als voordeel dat de geschatte aandelen van de beroepssegmenten per bedrijfssector optellen tot 1 . De prognoses per beroepssegment blijven daardoor consistent met de bedrijfssectorprognoses.

Naast een constante term die kan variëren tussen beroepssegmenten en bedrijfssectoren is als verklarende variabele in dit model een indicator voor de technologische ontwikkeling opgenomen. Deze indicator voor de technologische ontwikkeling, die een indicatie tracht te geven van de kapitaalintensiteit van het produktieproces, is bepaald op basis van de over 5 jaar gecumuleerde reële investeringen per bedrijfssector ten opzichte van de werkgelegenheid in de bedrijfssector. Er is verondersteld dat de invloed van deze indicator op de ontwikkeling van een bepaald beroepssegment voor alle bedrijfstakken waarin het betreffende beroepssegment voorkomt gelijk is.

Het model is geschat op basis van de AKT-reeks bedrijfssector $x$ beroepssegment voor de jaren 1979, 1981, 1983 en 1985. Vanwege genoemde databreuk konden de EBB-gegevens voor 1988 en 1989 nog niet gebruikt worden. Dat betekent dat er evenals bij de eerdere prognoses voor de periode 1985-1992 slechts vier waarnemingen in de tijd beschikbaar waren. Deze waren bovendien sterk gedateerd. Hierdoor waren de geschatte parameterwaarden in sommige gevallen niet plausibel. In deze gevallen is er voor gekozen het aandeel van het betreffende beroepssegment in de bedrijfssector constant te houden, dat wil zeggen dat het werkgelegenheidsaandeel in 1989 en 1994 is gelijk verondersteld aan het aandeel in 1985. Overigens is bij de bedrijfssector overheid het werkgelegenheidsaandeel van alle beroepssegmenten constant gehouden.

Vervolgens is de uitbreidingsvraag per beroepssegment verbijzonderd naar be- 
roepsklasse met behulp van een eenvoudig trendmodel. In dit model wordt het aandeel van het aantal werkenden in een beroepsklasse in een beroepssegment ten opzichte van het aantal werkenden in het referentieberoep verklaard uit een constante en een trend. Ook hier geldt dat als gevolg van de korte tijdreeks de uitkomsten voor sommige beroepsklassen implausibel waren. In dat geval is het aandeel in de totale werkgelegenheid per beroepssegment voor betreffende beroepsklassen constant gehouden.

Het hier beschreven model wijkt op een aantal punten af van het model dat gehanteerd is voor de prognoses tot 1992. Ten eerste is bij de prognoses voor de periode 1989-1994, zoals reeds werd opgemerkt, eerst een prognoses gemaakt van de werkgelegenheid per beroepssegment, terwijl voorheen de prognoses gelijk op het niveau van de beroepsklassen werden gemaakt. Verder kan in dit model de werkgelegenheidsontwikkeling van een beroep variëren tussen de verschillende bedrijfssectoren, terwijl in het oude model een beroepsklasse in alle sectoren eenzelfde ontwikkeling kreeg opgelegd ${ }^{6}$. Verder zorgt de gekozen specificatie ervoor dat de voorspelde aandelen altijd tussen 0 en 1 liggen en dat de som van de aandelen gelijk is aan 1 . Ten slotte is in de eerste stap van het model geen trendterm opgenomen. In het vorige model werd voor een aantal beroepen wel een trend opgenomen. Uit de in 1994 uitgevoerde evaluatie van die prognoses bleek dat gemiddeld genomen de prognoses voor deze beroepen beter waren dan voor beroepen waar geen trend werd opgenomen. Het ontbreken van een trend is daarom een mogelijke tekortkoming van dit nieuwe model. De drie eerstgenoemde veranderingen zijn waarschijnlijk wel een verbetering ten opzichte van het oude model.

Het toentertijd gehanteerde model komt echter nog niet tegemoet aan de belangrijkste tekortkoming die in het vorige evaluatierapport werd gesignaleerd. Dit betreft het feit dat vanwege de betrekkelijk korte tijdreeks waarop de schattingen zijn gebaseerd, de geëxtrapoleerde ontwikkelingen deels gebaseerd zijn op toevalligheden die schattingsfouten in het model veroorzaakten. Om die reden hebben Borghans en Heijke (1994) het beroepenmodel vervangen door een random-coëfficiënten-model. Hierin wordt bij onzekere schattingen de geconstateerde ontwikkeling met een groter conservatisme doorgetrokken dan bij schattingen met een lage standaarddeviatie. Om dit te kunnen bewerkstelligen is de eigenschap dat aandelen automatisch tot 1 optellen losgelaten. Simulaties tonen echter aan dat het achteraf corrigeren van deze mogelijke inconsistentie weinig invloed heeft op de prognoseresultaten.

6. Wel werden voorheen enerzijds de landbouw en de industriesectoren en anderzijds de dienstensectoren uit elkaar gehouden (zie Dekker, De Grip en Heijke, 1990). 


\section{Het opleidingenmodel}

Met betrekking tot de beroepsklasses wordt aangenomen dat de uitbreidingsvraag gelijk is aan de werkgelegenheidstoename. Dit betekent dat verwacht wordt dat werkgevers hun behoefte om bepaalde taken te laten vervullen in principe weten te realiseren. De voorspelde uitbreidingsvraag per opleidingstype is daarentegen niet per definitie gelijk aan de verwachte werkgelegenheidsontwikkeling. Als er bijvoorbeeld bij een gegeven vraag naar een bepaald opleidingstype sprake is van een aanbodoverschot, betekent dat niet per definitie dat schoolverlaters met deze opleiding werkloos worden. Mogelijk accepteren deze schoolverlaters minder aantrekkelijke banen dan die waarin ze voorheen werkzaam waren. De uiteindelijke werkgelegenheid voor een opleidingstype is dus zowel afhankelijk van vraag- als aanbodfactoren. Er moet daarom onderscheid worden gemaakt tussen de ex ante vraag, dat is de vraag die er zou zijn geweest bij gelijkblijvende schaarsteverhoudingen, en de ex post werkgelegenheid (zie Borghans, De Grip en Willems, 1995). Dat betekent dat het niet juist is om de voorspelde uitbreidingsvraag per opleidingstype te evalueren op basis van de feitelijke werkgelegenheidsontwikkeling. De ex ante vraag wordt immers niet rechtstreeks waargenomen. Alleen in samenhang met de verwachte aanbod-ontwikkelingen kan worden bepaald of de ex ante vraagprognoses een goed inzicht gaven in de toekomstige arbeidsmarktpositie van schoolverlaters. Hierop zal in hoofdstuk 7 worden ingegaan.

In het opleidingenmodel dat destijds is gehanteerd (Peeters, 1990), worden evenals bij het beroepenmodel twee stappen onderscheiden. Eerst is de vraag per opleidingsrichting bepaald, waarna de vraag per opleidingsrichting is verdeeld over de verschillende opleidingsniveaus ${ }^{7}$.

In het model wordt de opleidingenstructuur per bedrijfssector en per beroepssegment geanalyseerd. Ook hier is gebruik gemaakt van een verdeelmodel. In de eerste stap, waarin een verbijzondering in opleidingsrichting plaatsvindt is gebruik gemaakt van een eenvoudig trendmodel. De trend voor een bepaalde opleidingsrichting is in alle beroepen en bedrijfssectoren gelijk. De constante variabele in het model kan wel variëren tussen de verschillende bedrijfssectoren en de verschillende beroepen. In de tweede stap is gepoold over alle bedrijfssectoren. Dat betekent dat verondersteld is dat de ontwikkeling van een opleidingsniveau per opleidingsrichting en per beroepssegment gelijk is in alle sectoren. In het niveaumodel is nog een extra verklarende variabele opgenomen, namelijk de potentiële beroepsbevolking naar opleidingsrichting en -niveau. Verondersteld is dat een groter aanbod van personen met een bepaalde opleiding leidt tot een daling van de relatieve loonvoet

7. Deze stapsgewijze aanpak is overigens bij de latere prognoses niet meer toegepast. 
voor de werkenden met deze opleidingsachtergrond, waardoor het aandeel van deze opleidingscategorie in de totale werkgelegenheid toeneemt. De invloed van deze variabele is gelijk voor alle beroepssegmenten. Verder is in plaats van een constante term een vertraagde endogene variabele in het model opgenomen. De parameter van deze variabele kan variëren per onderwijsniveau en onderwijsrichting.

Een aantal opleidingstypen van gelijk niveau vallen binnen een opleidingsrichting. Voor deze opleidingen zijn vervolgens de prognoses per opleidingsrichting en opleidingsniveau nog verder verbijzonderd naar onderliggende opleidingstypen. Dit is gebeurd op basis van een trendmodel.

Het opleidingenmodel is geschat op basis van AKT-tabellen bedrijfssector $x$ beroepssegment $x$ opleidingsrichting $x$ opleidingsniveau. Waarschijnlijk mede omdat hier net als bij het beroepenmodel, sprake is van een zeer korte tijdreeks, resulteerden in een aantal gevallen niet plausibele prognoses. In deze gevallen zijn de aandelen van de desbetreffende opleidingstypen constant verondersteld.

Een mogelijk probleem van de gehanteerde aanpak is dat het voor kan komen dat voor twee opleidingstypen die een sterk overlappend beroependomein hebben sterk uiteenlopende arbeidsmarktperspectieven worden voorspeld. In de prognoses voor 1994 was dit bijvoorbeeld het geval bij WO Econom(etr)ie en Bedrijfskunde dat een slecht perspectief kende en HBO Economisch-Administratief waarvoor een goed perspectief werd voorzien. In dergelijke gevallen valt echter te verwachten dat de economen op WO-niveau mee zullen profiteren van het lage aanbod van economisch-administratief opgeleiden op HBO-niveau. In Borghans en Heijke (1996) is het opleidingenmodel aangepast zodat rekening gehouden kan worden met dergelijke substitutieprocessen. Verder is het door deze aanpak mogelijk werkgelegenheidsverschuivingen die veroorzaakt worden door veranderingen in de vraag te onderscheiden van werkgelegenheidsverschuivingen die veroorzaakt worden door veranderingen aan de aanbodkant.

\subsection{Empirische analyse uitbreidingsvraagprognoses}

In deze paragraaf worden de uitbreidingsvraagprognoses achtereenvolgens per bedrijfssector en beroepsklasse geëvalueerd. Bij een empirische evaluatie van de uitbreidingsvraag doen zich echter een aantal problemen voor. De prognoses die toentertijd zijn gemaakt hadden betrekking op alle werkenden ongeacht het aantal uren dat deze per week betaald werk verrichten. Sinds 1990 werkt het CBS met een andere definitie van werkzame bevolking. Alleen personen die minimaal 12 uur per week werken worden nog tot de beroepsbevolking gerekend. Dat betekent dat er voor 1994 alleen cijfers beschikbaar zijn voor mensen die 12 uur of meer per week 
werken. De prognoses zijn daarom niet direct te vergelijken met de realisaties. Voor het jaar 1990 is er echter zowel informatie beschikbaar over alle werkenden als over mensen die meer dan 12 uur per week werken. Op basis van deze informatie kan per beroepsklasse per bedrijfssector de verhouding van het aantal mensen dat minimaal 12 uur per week werkzaam is ten opzichte van het totaal aantal werkenden worden bepaald. Met deze verhoudingen uit 1990 is vervolgens het totaal aantal werkenden per bedrijfssector en per beroepssegment in 1994 geschat.

Verder wordt sinds 1992 bij personen met een aanstelling van minder dan een half jaar zonder vooruitzicht op verlenging het beroep niet meer gecodeerd. Daarom zal in vrijwel alle beroepen het waargenomen aantal werkenden in 1994 lager liggen dan het feitelijke aantal werkenden. Bovendien zal het aandeel van personen met een tijdelijk contract korter dan een half jaar waarschijnlijk sterk verschillen tussen de beroepssegmenten. De discrepantie tussen het werkelijke aantal werkenden en het waargenomen aantal werkenden is voor sommige beroepen derhalve groter dan voor andere beroepen. Ten slotte heeft er ook een verandering plaatsgevonden in de wijze waarop leidinggevenden worden gecodeerd in de EBB. Dergelijke veranderingen bemoeilijken het vergelijken van de realisaties met de prognoses. In principe wordt dit verschil echter gecompenseerd in de vergelijking met de Same As Before (SAB) prognose. Ook bij de SAB-prognose zullen de voorspelfouten immers groter worden als gevolg van deze meetverschillen. Bij specifieke beroepsklassen kan echter de SAB-prognose toevallig zeer goed zijn, terwijl de destijds opgestelde prognoses vanwege deze aanpassingen in de data een grote voorspelfout bevat.

\section{Uitbreidingsvraag per bedrijfssector}

Tabel 3.1 geeft per bedrijfssector een overzicht van de werkgelegenheid in arbeidsjaren in 1989, de prognose voor 1994 en de realisatie voor 1994, de voorspelfout en het verlies per bedrijfssector ${ }^{8,9}$. Het verlies is het grootst voor de chemische

8. Het gaat hier niet om de CPB-bedrijfssectorprognoses, maar om de aangepaste bedrijfssectorprognoses die het ROA heeft vastgesteld op basis van de CPB-prognoses. Overigens komt de bedrijfssectorindeling die hier wordt gepresenteerd niet exact overeen met de bedrijfssectorindeling in ROA (1992a), omdat in de beschikbare data voor 1994 enkele bedrijfssectoren zijn samengevoegd. De bedrijfssector overige industrie omvat de bedrijfssector kleding- en schoenenindustrie en de bedrijfssector hout- en bouwmaterialen, papier en grafische industrie. De bedrijfssector delfstoffen is nu ingedeeld bij de sector industrie.

9. Bij het opstellen van de prognoses is, zoals vermeld in paragraaf 3.2 , destijds gewerkt met een prognose voor 1989 en niet met realisaties voor 1989. De uitbreidingsvraag werd bepaald als verschil tussen de prognose voor 1994 en deze prognose voor 1989. De gebruikte methodiek laat impliciet hoe de voorspelde standcijfers voor 1994 vastgesteld moeten worden. Hier wordt verondersteld dat de uitbreidingsvraag opgeteld dient te worden bij de realisaties voor 1989. Daarom zijn in de tabel deze realisaties voor 1989 opgenomen. 
industrie en de metaalelektro-industrie. Bij beide sectoren blijft de gerealiseerde werkgelegenheidsgroei sterk achter bij de voorspelde groei. Verder is de werkgelegenheidsdaling in de landbouw flink onderschat. Terwijl werd voorspeld dat de werkgelegenheid in de landbouw met bijna $2,5 \%$ zou dalen is de werkgelegenheid in deze sector in werkelijkheid met ruim 12,5\% gedaald. Opvallend goed zijn de prognoses voor de sectoren vervoer en communicatie en kwartaire diensten.

Tabel 3.1

Voorspelfout aantal werkenden per Athena-bedrijfssector

\begin{tabular}{|c|c|c|c|c|c|}
\hline \multirow{2}{*}{$\begin{array}{l}\text { Bedrijfssector } \\
\text { Landbouw, visserij en tuinbouw }\end{array}$} & \multirow{2}{*}{$\begin{array}{l}\text { Aantal } \\
1989 \\
272.000\end{array}$} & \multirow{2}{*}{$\begin{array}{l}\text { Prognose } \\
1994 \\
266.000\end{array}$} & \multirow{2}{*}{$\begin{array}{l}\begin{array}{l}\text { Realisatie } \\
1994\end{array} \\
238.000\end{array}$} & \multicolumn{2}{|c|}{ Voorspelfout Verlies } \\
\hline & & & & 28.000 & 0,0135 \\
\hline Voedings- en genotm.industrie & 167.000 & 158.000 & 155.000 & 3.000 & 0,0005 \\
\hline Overige industrie & 293.000 & 286.000 & 272.000 & 14.000 & 0,0025 \\
\hline Chemie & 125.000 & 136.000 & 112.000 & 24.000 & 0,0437 \\
\hline Metaal, elektrotechnische & & & & & \\
\hline en transportmiddelenindustrie & 506.000 & 515.000 & 454.000 & 61.000 & 0,0179 \\
\hline Energie en delfstoffen & 53.000 & 53.000 & 52.000 & 1.000 & 0,0009 \\
\hline Bouw & 423.000 & 420.000 & 428.000 & -8.000 & 0,0003 \\
\hline Handel & 895.000 & 1014.000 & 961.000 & 53.000 & 0,0030 \\
\hline Vervoer en communicatie & 363.000 & 387.000 & 388.000 & -1.000 & 0,0000 \\
\hline Commerciële dienstverlening & 975.000 & 1085.000 & 1129.000 & -44.000 & 0,0016 \\
\hline Kwartaire diensten & 999.000 & 1080.000 & 1086.000 & -6.000 & 0,0000 \\
\hline $\begin{array}{l}\text { Openbaar bestuur, politie en } \\
\text { defensie en onderwijs }\end{array}$ & 879.000 & 890.000 & 905.000 & -15.000 & 0,0003 \\
\hline
\end{tabular}

In tabel 3.2 worden de bedrijfssectorprognoses vergeleken met de SAB-prognoses. Het gemiddelde verlies van de prognoses is veel lager dan het gemiddelde verlies van SAB-prognoses. De prognoses bevatten slechts $44 \%$ van de fout van de $\mathrm{SAB}$ prognose. De score van de relatieve bedrijfssectorprognoses is gelijk aan die van de absolute prognoses. Voornamelijk de slechte prognoses voor de metaal en elektrotechniek en de chemische industrie blijken de score te verslechteren. Ook de prognoses voor de landbouw en de handel dragen negatief bij aan de score. De prognoses voor de kwartaire dienstverlening hebben daarentegen een duidelijk positieve invloed op de score.

Geconcludeerd kan worden dat de bedrijfssectorprognoses voor 1994 dus vrij goed zijn geweest. Overigens dient hierbij opgemerkt te worden dat de bedrijfssectorprognoses een kortere termijn beslaan dan de prognoses voor de ontwikkelingen per beroepsklasse of opleidingstype. Toen de prognoses werden opgesteld beschikte het CPB immers reeds over informatie over 1990. Als deze aangepaste prognoses echter worden vergeleken met de oorspronkelijke CPB-bedrijfssectorprognoses, 
blijkt dat de CPB-prognoses een nog grotere voorspellende waarde hadden. De scores voor de absolute en relatieve CPB-prognoses bedragen respectievelijk 0,30 en 0,39 . Het aanpassen van de CPB-prognoses vanwege de discrepanties tussen AKT en EBB blijkt de voorspellingen dus niet te hebben verbeterd. Bij de latere prognoses heeft een dergelijke aanpassing, zoals reeds eerder werd opgemerkt overigens ook niet meer plaatsgevonden.

Tabel 3.2

Totaaloverzicht voorspelkwaliteit bedrijfssectorprognoses

\begin{tabular}{llll}
\hline & $\begin{array}{l}\text { Gem. verlies } \\
\text { prognose }\end{array}$ & $\begin{array}{l}\text { Gem. verlies } \\
\text { SAB }\end{array}$ & Score \\
\hline Prognose 1994 & & & \\
Absoluut & 0,0036 & 0,0080 & 0,44 \\
Relatief & 0,0031 & 0,0072 & 0,44 \\
Prognose 1992 & 0,0120 & & 0,47 \\
Relatief & & 0,0256 & \\
\hline
\end{tabular}

Tabel 3.2 geeft ten slotte aan dat de relatieve score van de aangepaste bedrijfssectorprognoses voor 1994 gradueel beter is dan de score voor deze prognoses uit 1992. Opvallend is echter dat het gemiddeld verlies substantieel lager is dan bij de vorige evaluatie. Echter ook het gemiddeld verlies van SAB is evenredig lager dan destijds. Deze aanzienlijke reductie van de voorspelfout wordt waarschijnlijk veroorzaakt door de kortere prognosetermijn. Bij de eerste prognoses werd feitelijk een voorspelling van zeven jaar van 1985 tot 1992 gemaakt, terwij verder de evaluatie destijds mogelijk vertekend werd door de overgang van AKT naar EBB. Overigens is ook het aantal onderscheiden bedrijfssectoren sterk afgenomen. Bij de prognoses voor 1992 werd nog voor 22 bedrijfssectoren een prognose opgesteld. Bij deze prognoses waren dat er slechts 14.

\section{Verklaring voorspelfouten bedrijfssectorprognoses}

Tabel 3.3 geeft een verklaring van de voorspelfouten en de standaarddeviatie van de voorspelfouten voor de uitbreidingsvraag per bedrijfssector. De onderschattingscoëfficiënt verschilt niet significant van 0 . Er kan dus niet geconcludeerd worden dat er sprake is van systematische over- of onderschatting van de werkgelegenheid per bedrijfssector. Bij de evaluatie van de prognoses voor 1992 werd een significante onderschatting van veranderingen geconstateerd. Mogelijk hangt dit samen met het kleiner aantal bedrijfssectoren dat wordt onderscheiden. 
Verwacht kan worden dat naarmate de omvang van een sector toeneemt de sectorprognoses minder nauwkeurig zullen zijn. Het blijkt dat de standaarddeviatie van de voorspelfouten inderdaad toeneemt met de omvang van een bedrijfssector maar deze toename is niet geheel proportioneel. Een vergelijkbaar schaaleffect werd ook bij de vorige evaluatie aangetroffen.

Tabel 3.3

Verklaring van voorspelfouten van de relatieve prognoses

\begin{tabular}{lcc}
\hline Variabele & Parameter & T-waarde \\
\hline Constante & 5,11 & 0,80 \\
Schaal & 0,60 & $1,80^{\star}$ \\
Onderschattingscoëfficiënt & 0,20 & 0,58 \\
\hline
\end{tabular}

* Significant bij betrouwbaarheid van $90 \%$

** Significant bij betrouwbaarheid van $95 \%$

\section{Uitbreidingsvraag per beroepsklasse}

Tabel 3.4 geeft een overzicht van de prognoseresultaten met betrekking tot de uitbreidingsvraag per beroepsklasse. In de tabel staan wederom achtereenvolgens het aantal werkzame personen per beroepsklasse in 1989, de prognose van het aantal werkzame personen in 1994 en de realisatie in 1994, alsmede de voorspelfout en het verlies per beroepsklasse. Voor een aantal beroepsklassen zijn de prognoses ronduit slecht. Voor technisch tekenaars werd bijvoorbeeld een werkgelegenheidsgroei van $66 \%$ voorspeld terwijl feitelijk de werkgelegenheid in dit beroep met ongeveer $2 \%$ is afgenomen. Voor technisch en medisch vertegenwoordigers werd een lichte afname van de werkgelegenheid voorspeld, terwijl de werkgelegenheid juist is verdubbeld.

Overigens worden de technisch en medisch vertegenwoordigers en de technisch tekenaars tot eenzelfde beroepssegment gerekend. In dit segment bevinden zich ook de ondernemers, uitvoerders en bedrijfskundigen. Vanwege het verdeelkarakter van de tweede stap van het beroepenmodel kan de voorspelling van de groei in een beroepsklasse van grote invloed zijn op de prognose van andere beroepsklassen in hetzelfde beroepssegment. Dit geldt met name als de omvang van de beroepsklassen sterk uiteen loopt. Bij dat beroepssegment is dat het geval. In 1989 waren er immers 266.000 ondernemers, uitvoerders en bedrijfskundigen, terwijl er toentertijd slechts 10.000 technisch en medisch vertegenwoordigers waren. Verder speelt bij dit beroepssegment een probleem met leidinggevenden. Vanwege een wijziging in de wijze van classificeren is er in 1992 sprake van een enorme trendbreuk die de sterk stijgende lijn afbreekt. Hierdoor is de SAB-prognose voor ondernemers, uitvoerders 


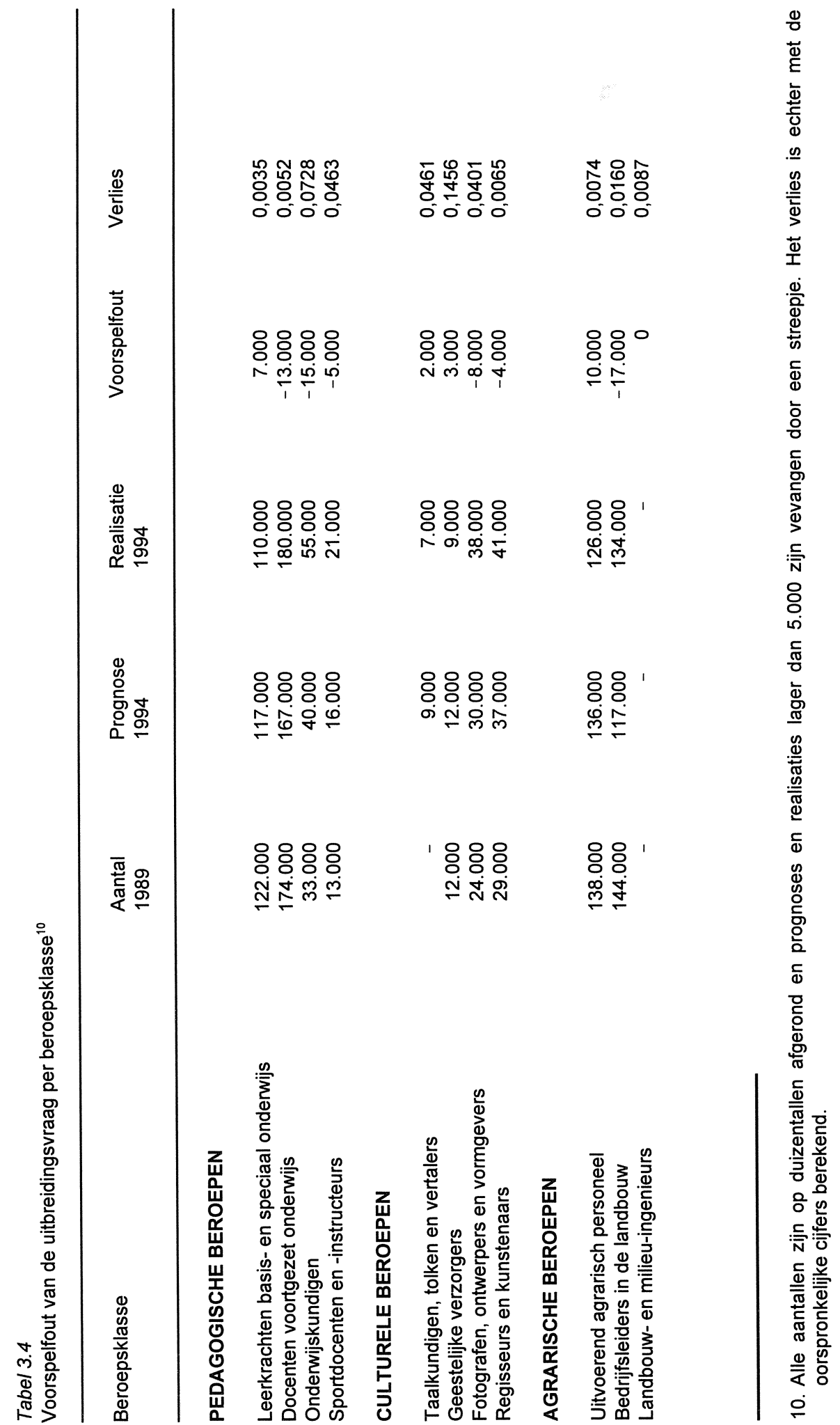




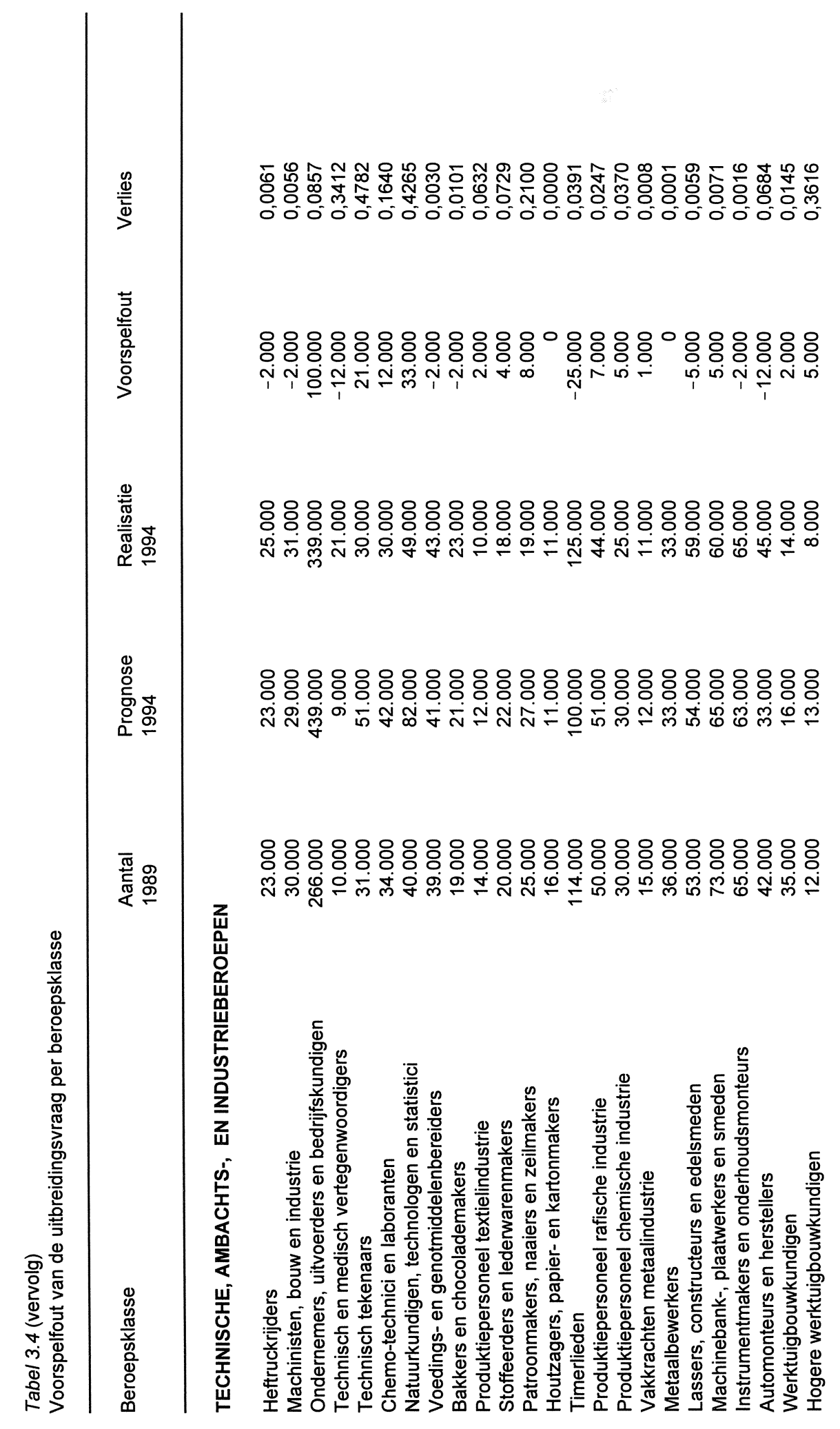




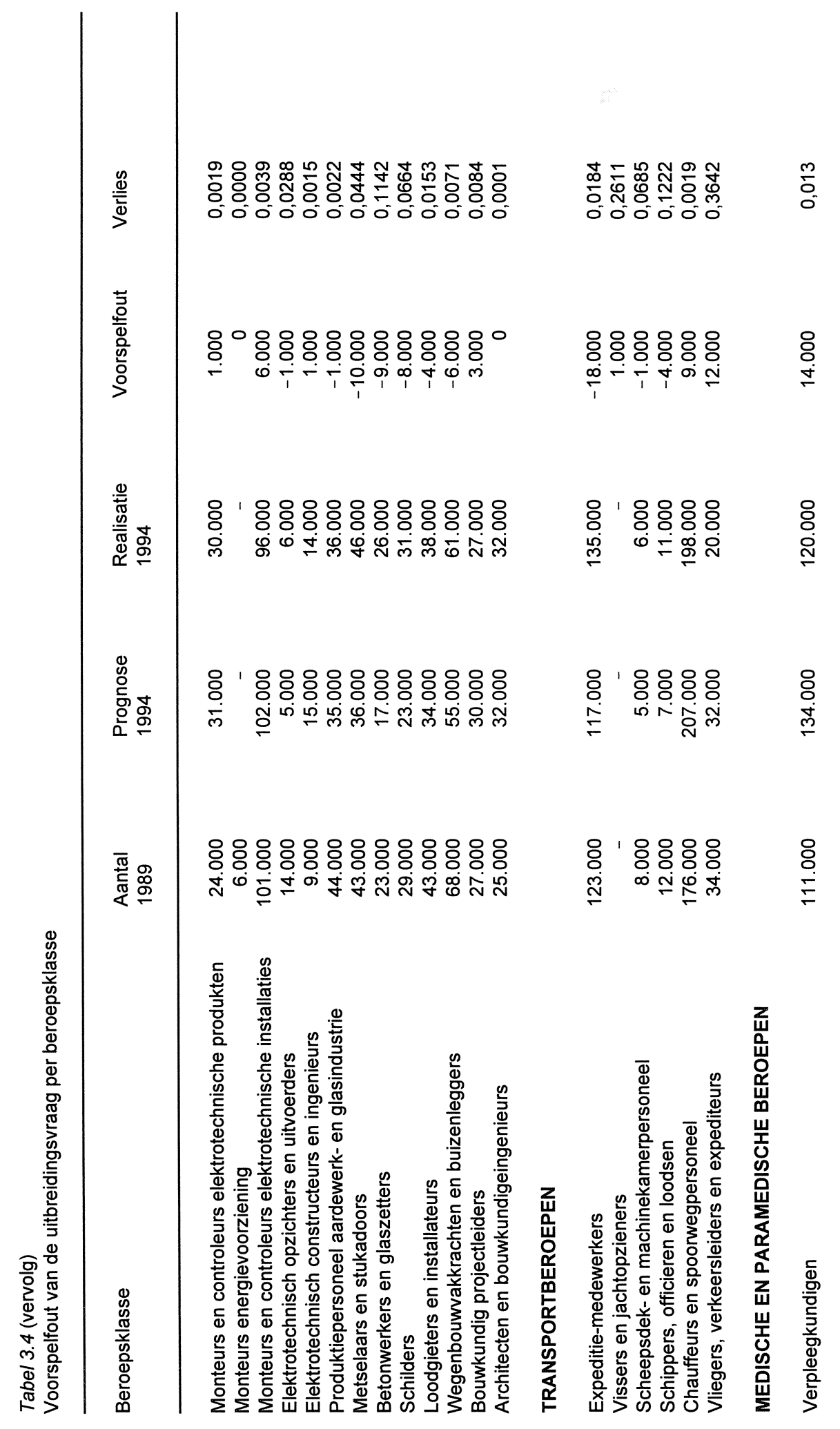




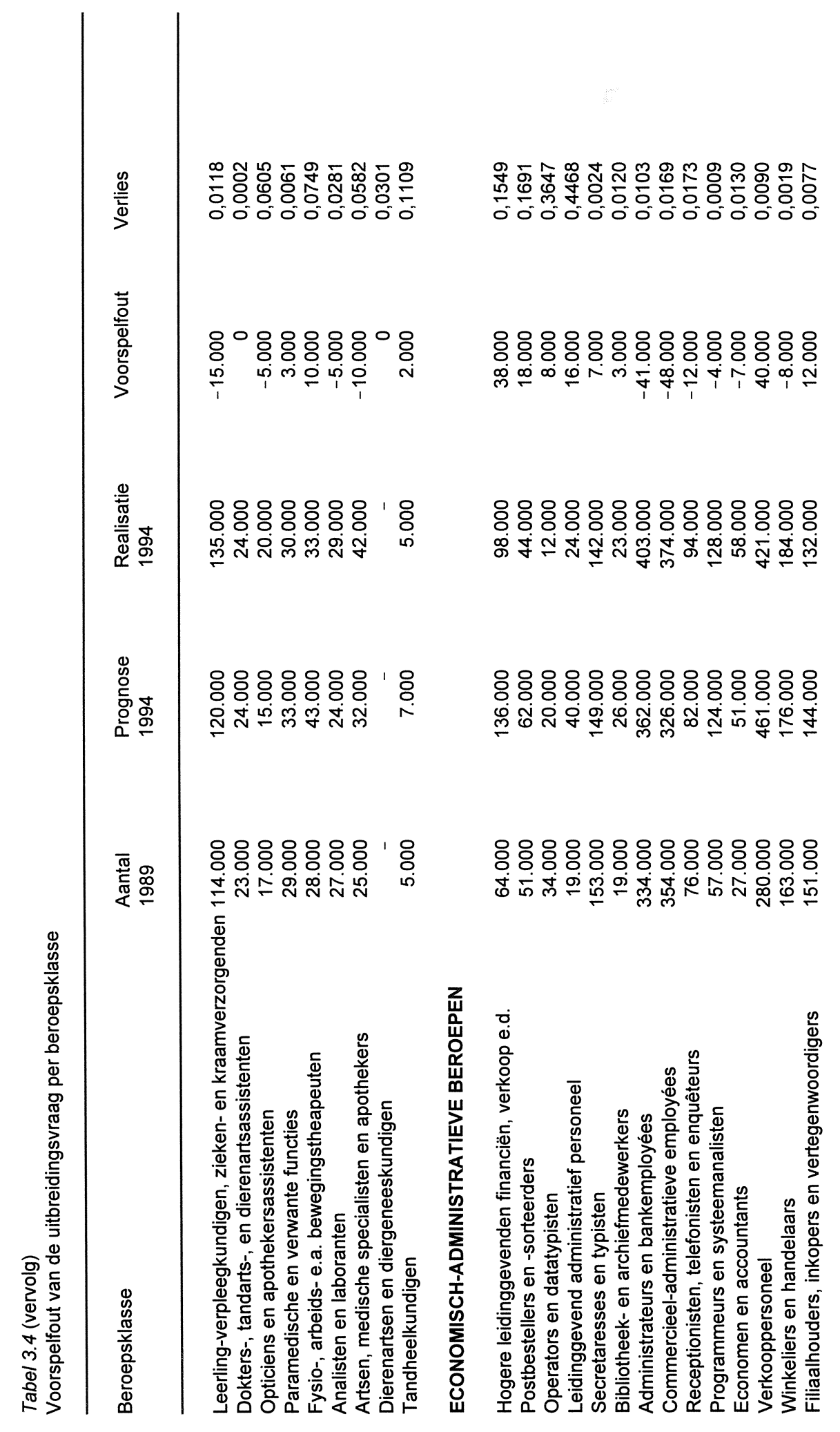




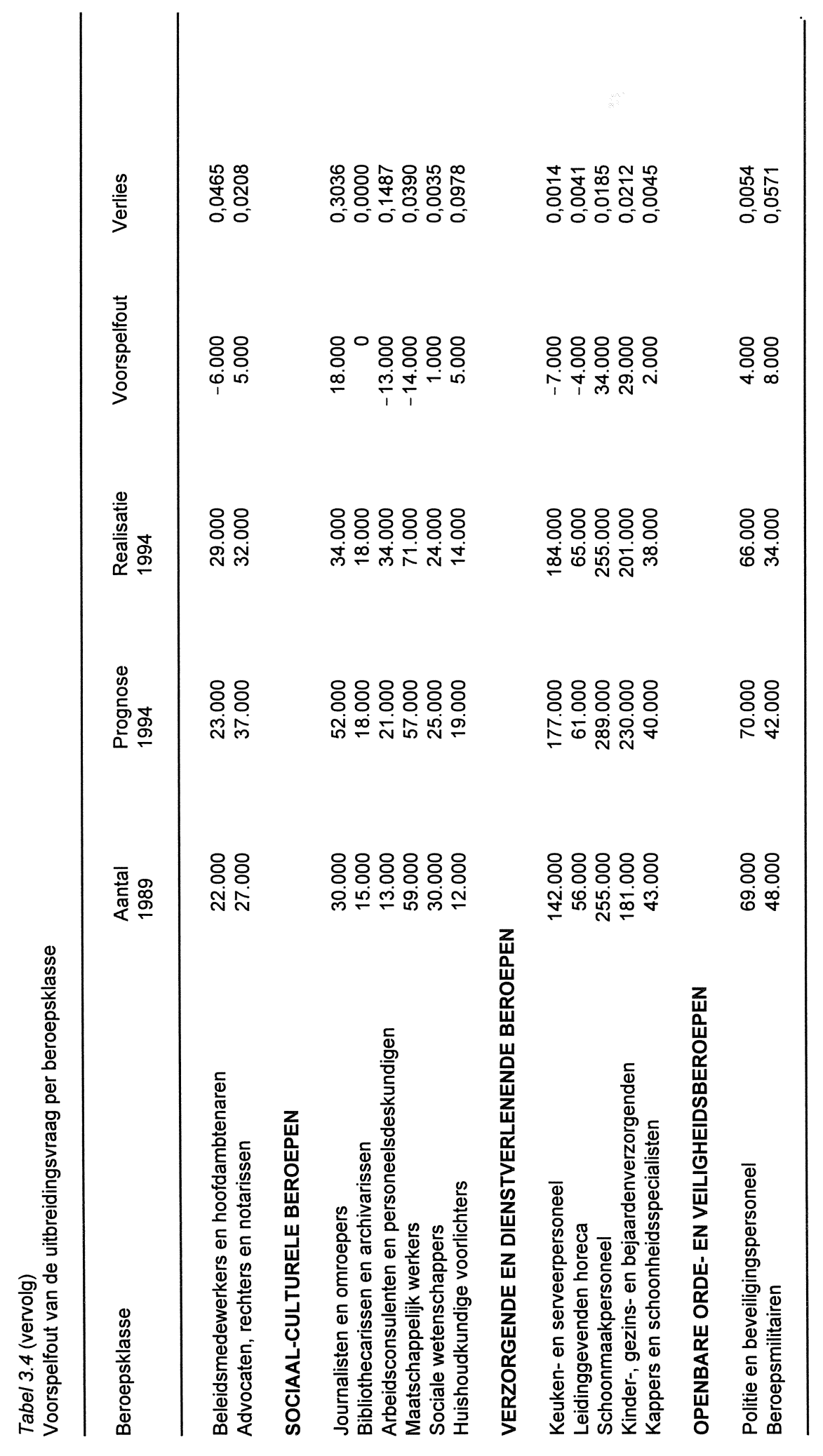


en bedrijfskundigen betrekkelijk goed.

Voor de natuurkundigen, technologen en statistici werd een verdubbeling van de werkgelegenheid voorspeld, terwijl de werkelijke groei ongeveer een kwart bedroeg. Eenzelfde overschatting van de werkgelegenheidstoename heeft zich voorgedaan bij het leidinggevend administratief personeel. Verder is het verlies groot voor constructeurs en klimaattechnici, vliegers, verkeersleiders en expediteurs, operators en datatypisten en journalisten en omroepers. Overigens valt op dat de uitschieters minder groot zijn dan bij de prognoses voor 1992. Ten slotte zijn er nog enkele beroepsklassen zeer goed voorspeld. Dat geldt voor de beroepsklasse houtzager, papier- en kartonmakers, vakkrachten metaalindustrie, metaalbewerkers, monteurs energievoorziening, architecten en bouwkundig ingenieurs, apothekersassistenten, dierenartsen en diergeneeskundigen en bibliothecarissen en archivarissen. Ook de zeer sterke toename van de werkgelegenheid voor programmeurs en systeemanalisten is vrij goed voorspeld.

\section{De voorspelkwaliteit}

Tabel 3.5 geeft een totaaloverzicht van de voorspelkwaliteit van de uitbreidingsvraag per beroepsklasse. Het gemiddeld verlies van zowel de absolute als de relatieve prognoses is substantieel lager dan het gemiddeld verlies van de prognoses voor 1992. Hierbij moet wederom bedacht worden dat destijds de prognoseperiode langer was, namelijk 7 jaar. Verder vertekende ook de overgang AKT-EBB de evaluatieresultaten negatief. Beide effecten hebben echter ook invloed op de SAB-prognose. Dit blijkt inderdaad uit de tabel.

Tabel 3.5

Totaaloverzicht voorspelkwaliteit prognoses uitbreidingsvraag per beroepsklasse

\begin{tabular}{llll}
\hline & $\begin{array}{l}\text { Gem. verlies } \\
\text { prognose }\end{array}$ & $\begin{array}{l}\text { Gem. verlies } \\
\text { SAB }\end{array}$ & Score \\
\hline Prognoses 1994 & & & \\
Absoluut & 0,0366 & 0,0580 & 0,63 \\
Relatief & 0,0344 & 0,0600 & 0,57 \\
Prognoses 1992 & & & 0,95 \\
Relatief & 0,0727 & 0,0767 & \\
\hline
\end{tabular}

Het verschil met de vorige prognoses is bij SAB echter kleiner. De score is daardoor aanmerkelijk beter dan bij de voorgaande prognoses. De absolute prognoses bevat- 
ten $63 \%$ van de voorspelfout van de $\mathrm{SAB}$ en de relatieve prognoses slechts $57 \%$. De prognose-resultaten ten opzichte van $S A B$ zijn voor de beroepsklassen overigens minder gunstig dan de score voor de bedrijfssectorprognoses. Dat duidt er op dat vooral voorspelfouten met betrekking tot de beroepenstructuur per bedrijfssector van belang zijn en minder de voorspelfouten in de prognoses van de werkgelegenheid per bedrijfssector. De score blijkt sterk negatief beïnvloed te zijn door de voorspelfouten bij de al eerder genoemde beroepsklassen ondernemers, uitvoerders en bedrijfskundigen, technisch tekenaars en natuurkundigen, technologen en statistici.

\section{Vaste-coëfficiëntenmethode}

Zoals reeds werd opgemerkt, wordt de werkgelegenheidsontwikkeling van een beroepsklasse bepaald door zowel de ontwikkeling van de totale werkgelegenheid in de bedrijfssectoren waar het beroep voorkomt, als door de ontwikkeling van het werkgelegenheidsaandeel van het beroep binnen deze bedrijfssectoren. In de prognosemethodiek worden beide componenten van de werkgelegenheidsontwikkeling vertegenwoordigd door respectievelijk de bedrijfssectorprognoses en het beroepenmodel. Het is interessant om een beeld te krijgen van de relatieve bijdrage van beide prognose-onderdelen voor de kwaliteit van de beroepsklasseprognoses. De evaluatieresultaten van beide onderdelen zijn echter niet volstrekt vergelijkbaar, omdat ze niet betrekking hebben op dezelfde indeling. De betekenis van de bedrijfssectorprognoses voor het voorspellen van de uitbreidingsvraag per beroepsklasse, kan onderzocht worden door deze prognoses door middel van een vaste-coëfficiëntenmodel op de beroepenindeling te projecteren.

In tabel 3.6. wordt aangegeven wat de prognoseresultaten zouden zijn geweest als de prognoses van de werkgelegenheidsontwikkeling per bedrijfssector achtereenvolgens op de situatie in het basisjaar 1989, de gehanteerde prognoses voor 1994 en de feitelijke situatie in 1994 zou zijn gebaseerd. Hierbij dient men zich te realiseren dat de realisatie in 1994 destijds niet beschikbaar was. Deze bedrijfssectorontwikkelingen zijn gecombineerd met achtereenvolgens de beroepenstructuur van 1989 en 1994. Ook deze beroepenstructuur van 1994 was toentertijd uiteraard nog niet bekend. De combinatie van basisjaar 1989 en beroepenstructuur 1989 komt overeen met de SAB-prognose. De combinatie van realisatie 1994 en beroepenstructuur 1994 betreft de feitelijke realisatie en heeft derhalve geen voorspelfout.

Uit de tabel blijkt dat als wordt uitgegaan van de bedrijfssectorprognoses, maar verondersteld wordt dat de beroepenstructuur van 1989 ongewijzigd blijft in de prognoseperiode, de prognoses vergeleken met $S A B$ sterk verbeteren. Het gemiddeld verlies komt op 0,0184. De scoreverhouding met SAB is 0,31 . Dit betekent dat de score op basis van de beroepenstructuurmatrix voor 1989 dus beter 
is dan de in tabel 3.5 weergegeven score van 0,57 op basis van de voorspelde beroepenstructuur. Dit verschil is waarschijnlijk te wijten aan de slechte voorspelling van enkele grote beroepsklassen, zoals de ondernemers, uitvoerders en bedrijfskundigen. Bovendien kan het beeld wat vertekend worden doordat banen van minder dan 12 uur per week in 1994 niet zijn gecodeerd waardoor de waargenomen beroepenstructuur zal afwijken van de werkelijke beroepenstructuur.

Tabel 3.6

Betekenis van de bedrijfsectorprognoses voor de uitbreidingsvraagprognoses naar beroepsklasse

\begin{tabular}{llll}
\hline $\begin{array}{l}\text { Bedrijfssector- } \\
\text { ontwikkeling }\end{array}$ & Beroepenstructuur & $\begin{array}{l}\text { Gemiddeld } \\
\text { verlies (absoluut) }\end{array}$ & $\begin{array}{l}\text { Gemiddeld } \\
\text { verlies (relatief) }\end{array}$ \\
\hline Basisjaar '89 & 1989 & 0,0580 & 0,0600 \\
Prognose '94 & 1989 & 0,0189 & 0,0184 \\
Realisatie '94 & 1989 & 0,0165 & 0,0178 \\
Basisjaar '89 & 1994 & 0,0113 & 0,0054 \\
Prognose '94 & 1994 & 0,0013 & 0,0012 \\
Realisatie '94 & 1994 & 0 & 0 \\
\hline
\end{tabular}

Het gemiddeld verlies gaat iets verder omlaag als niet van de prognoses, maar van de realisaties per sector wordt uitgegaan. De score ten opzichte van SAB komt nu op 0,28 . Hieruit blijkt dat de voorspelfouten in de bedrijfssectorprognoses slechts een zeer geringe negatieve invloed hebben gehad op de prognoses van de uitbreidingsvraag per beroepsklasse. Bij de vorige evaluatie bleek juist dat de bedrijfssectorprognoses - die opzichzelf van vergelijkbare kwaliteit waren nauwelijks een verbetering van de beroepsklasseprognoses bewerkstelligden, vergeleken met SAB. Kennelijk waren destijds de verschuivingen in de bedrijfssectorstructuur nauwelijks van invloed op de werkgelegenheidsontwikkelingen per beroepsklasse, terwijl voor de prognoses die thans worden geëvalueerd deze bedrijfssectorveranderingen voor een aanzienlijk deel de verschuivingen per beroepsklasse blijken te kunnen verklaren. Het is echter niet duidelijk waardoor dit wezenlijke verschil veroorzaakt wordt. Een mogelijke verklaring kan wederom de overgang van AKT naar EBB zijn, waardoor de waargenomen veranderingen in de beroepenstructuur dermate omvangrijk waren dat de bedrijfssectorverschuivingen erbij in het niet vielen. Gezien het belang van de bedrijfssectorprognoses voor de kwaliteit van de uitbreidingsvraagprognoses per beroepsklasse zou overwogen kunnen worden het aantal onderscheiden bedrijfssectoren uit te breiden. De invloed hiervan op de uiteindelijke kwaliteit van de prognoses hangt echter sterk af van de kwaliteit van de bedrijfssectorprognoses op het aggregatieniveau dat dan gehanteerd zou worden. 
De tabel geeft ook het gemiddelde verlies als wordt uitgegaan van de structuurmatrix van 1994. Als zou zijn uitgegaan van de bedrijfssectorverdeling uit het basisjaar, maar de veranderingen in de beroepenstructuur per bedrijfssector volledig juist zouden zijn voorspeld, dan zou de voorspelkracht aanzienlijk groter zijn geweest dan bij de varianten waarin gekeken wordt naar de invloed van werkgelegenheidsverschuivingen per bedrijfssector. Hieruit blijkt dat het van groot belang is rekening te houden met veranderingen in de beroepenstructuur van bedrijfssectoren. Prognoses op basis van de werkgelegenheid per bedrijfssector in 1989 maar met de structuurmatrix van 1994 geven namelijk een lager verlies dan wanneer wordt uitgegaan van de bedrijfssectorprognoses voor 1994 of de bedrijfssectorrealisaties voor 1994 in combinatie met de beroepenstructuurmatrix voor 1989. Als wordt uitgegaan van zowel de bedrijfssectorprognoses als de structuurmatrix voor 1994 is het verlies zeer laag: 0,0013. Dat leidt tot een score ten opzichte van SAB van 0,02 .

Geconcludeerd kan worden dat zowel de veranderingen in de bedrijfssectorstructuur als veranderingen in de beroepenstructuur van belang zijn ter verklaring van de uitbreidingsvraag per beroepsklasse. Echter, hoewel de invloed van de beroepenstructuur op de uitbreidingsvraag het grootst is, is bij de beroepenprognoses voor 1994 de grootste bijdrage aan de voorspelkwaliteit toe te schrijven aan de bedrijfssectorprognoses.

\section{Verklaring van voorspelfouten}

Tabel 3.7 geeft een verklaring voor de voorspelfout en de standaarddeviatie van deze voorspelfout voor de uitbreidingsvraagprognoses per beroepsklasse. Het blijkt dat er sprake is van systematische overschatting van de veranderingen. Dit impliceert waarschijnlijk dat de prognoses relatief veel ruis bevatten. Dat betekent dat er veranderingen zijn voorspeld die niet hebben plaatsgevonden. Bij de vorige evaluatie werd deze overschatting ook aangetroffen. Destijds bleek dat met name bij beroepsklassen waar een trendmodel was gehanteerd een aanzienlijke ruis voor te komen. Bij de prognoses die hier worden geëvalueerd is in principe altijd een trendterm toegepast bij de verdeling van de werkgelegenheidsontwikkeling per beroepssegment over de beroepsklassen. Hoewel het effect van de trendterm hierdoor niet meer te toetsen is, ligt het voor de hand dat ook hier een trendmode vaak tijdelijke effecten ten onrechte extrapoleert. Inmiddels wordt de werkgelegenheidsontwikkeling per beroepsklasse voorspeld met behulp van een randomcoëfficiëntenmodel. Hierin wordt bij het extrapoleren van trends rekening gehouden met de statistische betrouwbaarheid ervan. Door dit principe wordt een zeker conservatisme in de prognoses ingebouwd, waarvan op de grond van deze evaluatieresultaten verwacht mag worden dat het een positieve bijdrage levert aan de voorspelkwaliteit. Verder lijkt het ook van belang om rekening te houden met de tijdelijkheid van de waargenomen trendmatige ontwikkelingen. In de gehanteerde 
modellen wordt een in de tijd constante trendterm gebruikt. Het ligt echter voor de hand om - zeker als de beschikbare tijdreeksen langer worden - rekening te houden met omslagen in de trendmatige ontwikkeling.

Tabel 3.7

Een verklaring van de voorspelfouten in de relatieve uitbreidingsvraagprognoses per beroepsklasse

\begin{tabular}{lrc}
\hline Variabele & Parameter & T-waarde \\
\hline & & \\
Constante & 2,88 & $3,17^{\star *}$ \\
Schaal & 0,55 & $6,56^{\star *}$ \\
Spreidingsindicator & 0,84 & $3,10^{\star *}$ \\
Conjunctuurindicator & $-0,31$ & $-2,38^{\star *}$ \\
Onderschattingscoëfficiënt & $-0,34$ & $-5,23^{\star *}$
\end{tabular}

* significant bij betrouwbaarheid van $90 \%$

${ }^{* *}$ signifcant bij betrouwbaarheid van $95 \%$

De tabel geeft verder een verklaring van de standaarddeviatie van de voorspelfout. Deze is afhankelijk verondersteld van de grootte van de te voorspellen beroepsklasse, de spreiding van de beroepsklasse over de verschillende bedrijfssectoren en de mate waarin de werkgelegenheid in de desbetreffende beroepsklasse conjunctuurgevoelig is. Naarmate de beroepsklasse groter is wordt de voorspelling in absolute termen uiteraard minder nauwkeurig. Dit schaaleffect is iets lager dan bij de vorige prognoses. Verwacht mag worden dat de voorspelling minder nauwkeurig is naarmate de bedrijfssectorspreiding lager is. Als een beroepsklasse slechts in een enkele bedrijfssector voorkomt dan heeft een onvoorziene schok in deze bedrijfssector grotere invloed op de totale werkgelegenheidsontwikkeling van het beroep dan wanneer de werkgelegenheid van een beroep over meerdere bedrijfssectoren is verspreid. Als een beroep erg conjunctuurgevoelig is dan zal de voorspelling waarschijnlijk minder nauwkeurig zijn omdat een conjuncturele op- of neergang veel invloed heeft op de feitelijke werkgelegenheidsontwikkelingen.

Het blijkt echter dat in tegenstelling tot wat verwacht zou mogen worden de nauwkeurigheid van de voorspellingen positief samenhangt met de spreidingsindicator en negatief met de conjunctuurindicator. Beide effecten zijn ook significant. Dit effect wordt waarschijnlijk verklaard door het feit dat beroepen waarvan de werkgelegenheid slechts in een enkele bedrijfssectoren is geconcentreerd, vaak ook een groot aandeel in de werkgelegenheid in deze bedrijfssectoren hebben. De voorspellingen van de werkgelegenheidsontwikkelingen van deze beroepen binnen de desbetreffende sectoren zijn daarom nauwkeuriger. Beroepen die in veel bedrijfssectoren voorkomen zijn, naar verhouding binnen de bedrijfssector kleiner 
en, de werkgelegenheidsontwikkelingen van deze beroepen binnen deze bedrijfssectoren zijn daarom minder nauwkeurig te voorspellen. Het effect van de conjunctuurindicator wordt in de vorige evaluatiestudie verklaard door het feit dat de prognoses voor de industriële sectoren beter zijn dan voor de andere sectoren, terwijl juist de conjunctuurgevoeligheid van beroepen in de industriële beroepen hoger is. Deze verklaring lijkt in dit geval echter niet op te gaan.

\section{Kwalitatieve typeringen}

Om de prognoses beter interpreteerbaar te maken en rekening te houden met een bepaalde bandbreedte om de exacte puntprognoses, is aan elke prognose een kwalitatieve typering toegevoegd. De indeling van de kwalitatieve typeringen van de uitbreidingsvraag per beroepsklasse is als volgt:

\begin{tabular}{|c|c|c|c|c|c|}
\hline & & UVB & $\leq$ & $-18 \%$ & erg laag \\
\hline$-18 \%$ & $<$ & UVB & $\leq$ & $0 \%$ & laag \\
\hline $0 \%$ & $<$ & UVB & $\leq$ & $13 \%$ & gemiddeld \\
\hline $13 \%$ & $<$ & UVB & $\leq$ & $26 \%$ & hoog \\
\hline $26 \%$ & $<$ & UVB & & & erg hoog \\
\hline
\end{tabular}

waarbij UVB staat voor uitbreidingsvrag per beroepsklasse (Dekker e.a., 1992).

Tabel 3.8

Typeringen van de uitbreidingsvraag per beroepsklasse (relatief)

\begin{tabular}{lcccccc}
\hline & \multicolumn{5}{c}{ Prognose } \\
Realisatie & erg laag & laag & gemiddeld & hoog & erg hoog & totaal \\
\hline Erg laag & 7 & 5 & 3 & 0 & 0 & 15 \\
Laag & 4 & 9 & 4 & 2 & 0 & 19 \\
Gemiddeld & 2 & 9 & 5 & 2 & 2 & 20 \\
Hoog & 1 & 2 & 6 & 2 & 6 & 17 \\
Erg hoog & 0 & 1 & 2 & 2 & 17 & 22 \\
Totaal & 14 & 26 & 20 & 8 & 25 & 93 \\
\hline
\end{tabular}

Tabel 3.8 geeft de realisatie van deze typeringen ten opzichte van de prognoses. Het blijkt dat 40 van de 93 beroepen een juiste typering van de werkgelegenheidsontwikkeling hebben gekregen. Dat is $43 \%$ van alle beroepsklassen. Als daaraan de beroepsklassen worden toegevoegd waarvan de gerealiseerde typering slechts éen categorie naast de voorspelde typering ligt dan blijkt dat voor 79 beroepen ( $85 \%$ ) een goede of vrij goede typering is gegeven. Deze resultaten zijn aanzienlijk beter 
dan bij de prognoses tot 1992 . Toen werd in $61 \%$ van de gevallen een goede of redelijke typering gegeven.

Er zijn slechts een paar beroepsklassen waarvan de typering van de prognose in een tegengestelde richting wijst als de typering van de realisatie. Voor de technisch en medisch vertegenwoordigers, betonwerkers en glaszetters, opticiens en apothekersassistenten en maatschappelijk werkers was de voorspelde groei erg laag tot laag, terwijl de gerealiseerde groei hoog tot erg hoog getypeerd kan worden. Voor de chemotechnici en laboranten werd daarentegen juist een hoge groei voorspeld, terwijl de achteraf weergegeven werkgelegenheidsontwikkeling als laag getypeerd moet worden.

Uit deze resultaten blijkt ook dat niet alle beroepsklassen met grote voorspelfouten ook in de verkeerde richting zijn getypeerd. Dat geldt bijvoorbeeld voor de natuurkundigen, technologen en statistici. De voorspelfout bij deze beroepsklasse is erg groot. De kwalitatieve typering van die werkgelegenheidsgroei ligt echter slechts één categorie naast de gerealiseerde groei. De voorspelde groei was zeer hoog, de gerealiseerd groei hoog. Met name bij sterk groeiende of sterk dalende beroepen, blijkt de juiste schatting van de precieze omvang van deze groei niet relevant voor de juistheid van de kwalitatieve typering. Op deze relatie tussen prognose en typering is uitgebreid ingegaan in het vorige evaluatierapport.

\subsection{Een vergelijking met eerdere uitbreidingsvraagprognoses}

In de vorige paragraaf bleek al dat de kwaliteit van de uitbreidingsvraagprognoses hoger is dan die van de eerder gemaakte prognoses voor 1985-1992. Omdat de voorspelkwaliteit sterk samenhangt met de omvang van de te voorspellen categorie, zal in deze paragraaf een vergelijking tussen beide prognoses worden gemaakt, waarin met name op dit schaaleffect wordt ingegaan. Bij deze eerdere prognoses werd, zoals in paragraaf 3.2 al werd opgemerkt, een andere beroepenclassificatie gehanteerd. In deze paragraaf zal onder meer worden bekeken in welke mate verschillen in voorspelkwaliteit tussen beide prognoses samenhangen met deze verandering van classificatie.

Op basis van een schatting van vergelijking (7) uit hoofdstuk 2, is het verband tussen de voospelfout en de schaal van de voorspelde beroepsklasse onderzocht. Figuur 3.1 geeft voor beide prognosejaren zowel de verwachte standaarddeviatie van de ROA-prognoses als $S A B$, afgezet tegen de schaal ${ }^{11}$. In de figuur is te zien

11. Hierbij is de restrictie opgelegd dat de schaal naast de constante de enige verklarende variabele in het model is. 
dat de verwachte standaarddeviatie in alle gevallen minder dan evenredig met de voorspelfout toeneemt. Dit impliceert dat het gemiddeld verlies voor een indeling in een beperkt aantal grote categorieën, lager zal zijn dan het gemiddeld verlies voor een meer verfijnde indeling. De bruikbaarheid van prognoses wordt echter niet alleen bepaald door het gemiddeld verlies, maar ook door de informatiewaarde van de gekozen indeling. Er moet daarom een afweging worden gemaakt tussen de grotere betrouwbaarheid bij grotere categorieën en de extra informatie die verkregen wordt uit een verdere verbijzondering van de indeling.

Figuur 3.1

Verwachte standaarddeviatie prognoses en SAB, 1992 en 1994

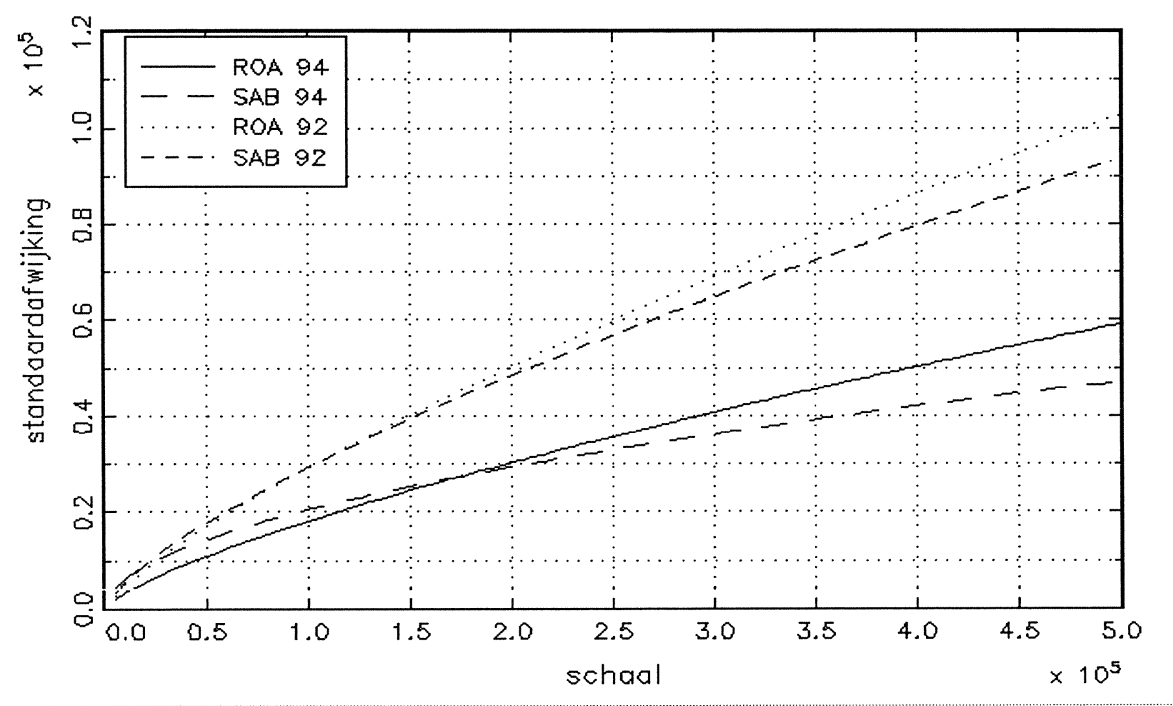

Verder blijkt uit de figuur dat de standaardfouten van de prognoses voor 1992 van zowel de SAB- als de ROA-prognoses aanmerkelijk hoger zijn dan de standaardfouten voor 1994. Figuur 3.2 geeft de scoreverhouding tussen de standaardfout van de ROA-prognoses en SAB. Zowel bij de prognoses voor 1992 als bij de prognoses voor 1994 worden met name de kleine beroepsklassen goed voorspeld. Kleinere beroepsklassen maken relatief grotere veranderingen door, waardoor het beroepenmodel hier beter voorspelt dan Same As Before. Bij de grotere beroepsklassen zijn de relatieve veranderingen kleiner, waardoor kennelijk de ruis vanwege schattingsfouten belangrijker wordt. Verder blijkt dat ook de verdere verbetering van de prognoses, zowel ten opzichte van $S A B$ als ten opzichte van de vorige prognoses, vooral heeft plaatsgevonden bij de kleinere beroepsklassen. Bij de prognoses voor 1992 zijn de ROA-prognoses gemiddeld alleen beter dan SAB bij beroepsklassen met minder dan 100.000 werkenden. Bij 100.000 werkenden overschreidt de scorecurve immers de 1 . Bij de prognoses tot 1994 ligt deze grens bij 175.000 werkenden. 
20 van de 93 beroepsklassen hebben 100.000 of meer werkenden. Er zijn echter slechts tien beroepsklassen waar minstens 175.000 personen werkzaam zijn. Verder blijkt dat de prognoses tot 1994 relatief beter zijn dan de eerdere prognoses voor beroepen met minder dan 200.000 werkenden. Bij beroepen met meer dan 200.000 werkenden zijn de eerdere prognoses naar verwachting juist beter. Dit betreft zes grote beroepsklassen.

Figuur 3.2

Verwachte standaarddeviatie prognoses ten opzichte van SAB, 1992 en 1994

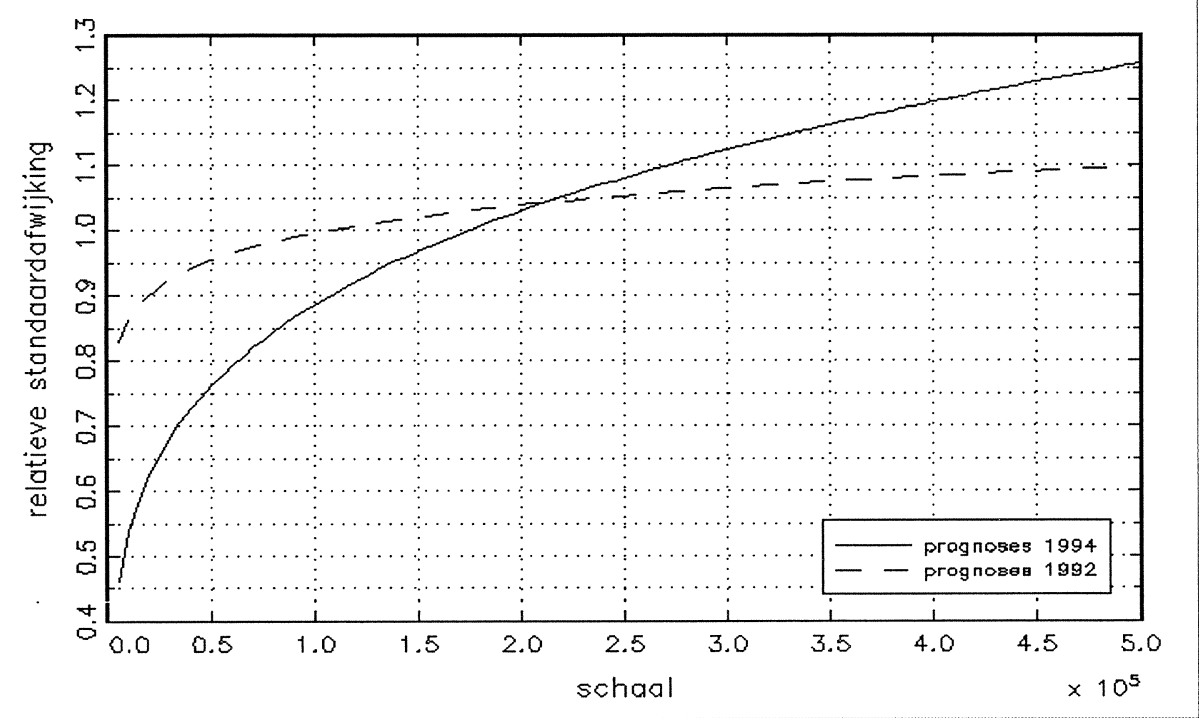

Zoals reeds is opgemerkt is bij de prognoses voor 1992 een andere beroepenclassificatie gehanteerd dan bij de prognoses voor 1994. Vanwege het geconstateerde schaaleffect is de gehanteerde classificatie van grote invloed op het gemiddeld verlies van de prognoses. De classificatie bepaalt immers de ligging van de te voorspellen categorieën op de schaal-as in de figuren 3.1 en 3.2. Op basis van de voorspelde standaarddeviatie kan het verwachte gemiddelde verlies van de prognoses tot 1992 en de prognoses tot 1994 worden bepaald voor beide classificaties $^{12}$. Uit tabel 3.9 blijkt dat het verwachte gemiddeld verlies van beide

12. Het verwachte gemiddelde verlies wordt in deze paragraaf als volgt bepaald:

$$
G \hat{V}(\hat{x})=\sum_{i} \frac{1}{y^{\text {tot }}} \frac{\sigma_{i}^{2}\left(y_{i}\right)}{y_{i}}
$$

en is bij benadering gelijk aan het gemiddeld verlies zoals gedefinieerd in paragraaf 2.2 . 
prognoses lager is als wordt gewerkt met de oude beroepenclassificatie. Als bij de prognoses voor 1992 reeds de nieuwe classificatie zou zijn gebruikt, zou het gemiddeld verlies hoger zijn uitgevallen. Omgekeerd zouden de prognoses voor 1994 een lager gemiddeld verlies hebben gehad als nog met de vorige classificatie zou zijn gewerkt. Dit resultaat kan verklaard worden uit het feit dat in de nieuwe classificatie het aantal werkzame personen in de onderscheiden beroepsklassen minder varieert dan bij de oude classificatie. Als de beroepsklassen allemaal ongeveer dezelfde omvang hebben, zal het gemiddeld verlies hoger zijn, dan als er grote verschillen in omvang zijn. De positieve invloed van een zeer grote beroepsklasse op het gemiddeld verlies is groter dan de negatieve invloed van een zeer kleine beroepsklasse. Het is belangrijk om op te merken dat het hier overigens alleen gaat om de invloed van de schaal op de prognoses en niet om de kwaliteit van de gebruikte classificatie. De ongunstige invloed van de schaal van de nieuwe classificatie op de voorspelkwaliteit kan weer gecompenseerd worden door kwaliteitsverbetering die het gevolg is van de betere (evenwichtigere) beroepenindeling. Het feit dat het gemiddeld verlies van de prognoses tot 1994 voor beide classificaties lager is dan het gemiddeld verlies van de eerder prognoses wijst ook in deze richting. Dit effect kan echter niet los van andere invloeden gemeten worden Verder is voor de keuze van de classificatie niet alleen het gemiddeld verlies bij prognoses doorslaggevend. Tegenover de relatief kleinere voorspelfout bij grote beroepsklassen staat immers het informatieve voordeel van meer specifieke beroepsklassen. Voor een adequate beroepenindeling lijkt daarom, zoals reeds werd opgemerkt, een goede afweging van voorspelkwaliteit en de informatiewaarde van de onderscheiden beroepen van belang.

Tabel 3.9

De relatie tussen het gemiddeld verlies van de prognoses en de gehanteerde classificatie

\begin{tabular}{lll} 
& Prognose 1992 & Prognose 1994 \\
\hline Classificatie '92 & 0,0762 & 0,0298 \\
Classificatie '94 & 0,0875 & 0,0352 \\
\hline
\end{tabular}

Tabel 3.10 geeft het verwachte gemiddeld verlies van $S A B$ voor de prognoses van 1992 en 1994 op basis van beide classficaties. Uit de tabel blijkt dat de SABprognoses nog sterker verbeteren dan de ROA-prognoses als de oude classificatie wordt gebruikt in plaats van de nieuwe classificatie. Uit figuur 3.2 bleek al dat SAB met name grote beroepsklassen goed voorspelt. Dat leidt er toe dat, zoals blijkt in tabel 3.11, de scores voor de ROA-prognoses beter zijn als de classificatie van 1994 wordt gebruikt. Dat betekent dat bij de evenwichtigere beroepenclassificatie die sinds de prognoses voor 1994 is gehanteerd, het voordeel van het gehanteerde 
beroepenmodel ten opzichte van SAB groter is geworden dan bij de oude indeling die relatief veel extreem grote beroepsklassen kende. Ruwweg kan gesteld worden dat $13 \%$ van de verbetering van de score van de uitbreidingsvraagprognose per beroepsklasse voortkomt uit de aangepaste beroepenclassificatie.

Tabel 3.10

De relatie tussen het gemiddeld verlies van $S A B$ en de gehanteerde classificatie

\begin{tabular}{lll} 
& Prognose 1992 & Prognose 1994 \\
\hline Classificatie '92 & 0,0777 & 0,0465 \\
Classificatie '94 & 0,0923 & 0,0600 \\
\hline
\end{tabular}

Tabel 3.11

De relatie tussen score van de prognoses en de gehanteerde classificatie

\begin{tabular}{lll} 
& Prognose 1992 & Prognose 1994 \\
\hline Classificatie '92 & 0,98 & 0,64 \\
Classificatie 94 & 0,95 & 0,59 \\
\hline
\end{tabular}

\subsection{Conclusies}

Samenvattend kan gesteld worden dat de uitbreidingsvraagprognoses per beroepsklasse voor de periode 1989-1994 aanmerkelijk verbeterd zijn ten opzichte van de eerdere prognoses voor de jaren 1985-1992. De belangrijkste bijdrage aan deze verbetering komt voort uit het feit dat de, relatief goed voorspelde, bedrijfssectorontwikkelingen meer invloed hadden op de uitbreidingsvraag per beroepsklasse dan bij de prognoses voor 1992. Verder heeft de modelaanpassing waardoor de relatieve werkgelegenheidsontwikkeling per beroepssegment kan variëren tussen de bedrijfssectoren waarschijnlijk een gunstige invloed gehad. Een probleem bij de prognosemethodiek die destijds werd gehanteerd blijft echter de grote invloed van schattingsruis op de prognoses. Verder blijkt de keuze omtrent het al dan niet opnemen van een trendvariabele evenals bij de vorige evaluatie problematisch te zijn. De overstap naar een random-coëfficiënten-model die voor het eerst bij de prognoses voor de periode 1993-1998 heeft plaatsgevonden kan voor beide aspecten een verbetering betekenen.

Voor de verdere ontwikkeling van het prognosemodel voor de uitbreidingsvraag naar beroepsklasse zal met name gekeken moeten worden naar de specificatie van de 
trend in het model en moet onderzocht worden of het onderscheiden van meer bedrijfssectoren een positieve bijdrage aan de prognoses kan leveren. Ten slotte zal verder onderzoek gedaan moeten worden om de verklarende variabelen verder te verbeteren. Uit het feit dat met name kleinere beroepsklassen goed voorspeld worden blijkt de mogelijke bijdrage van een goed verklarend model. 



\section{De vervangingsvraag}

\subsection{Inleiding}

De tweede component van de prognoses in het informatiesysteem onderwijsarbeidsmarkt heeft betrekking op de vervangingsvraag. Deze vormt samen met de uitbreidingsvraag de baanopeningen per beroepsklasse of opleidingstype. Bij het opstellen van de prognoses waarop deze evaluatie betrekking heeft, is daadwerkelijk de vervangingsvraag voorspeld. Dit in tegenstelling tot de eerdere prognoses, waarbij in feite de uitstroom van werkenden werd voorspeld. In dit hoofdstuk wordt allereerst ingegaan op de methodiek die gehanteerd is bij de vervangingsvraagprognoses. Daarna wordt ingegaan op de empirische resultaten van de evaluatie van de prognoses.

\subsection{Prognosemethodiek}

Naast de uitbreidingsvraag vormt ook de vervangingsvraag een belangrijke component van de baanopeningen per beroepsklasse of opleidingstype. Met name schoolverlaters van VBO- en MBO-richtingen zijn voor hun werkgelegenheid in hoge mate afhankelijk van het vertrek van oudere werknemers. Voor een goed beeld van hun arbeidsmarktperspectieven is de vervangingsvraag daarom cruciaal. Om die reden zijn in het informatiesysteem onderwijs-arbeidsmarkt vanaf het begin beide componenten van de vraag - uitbreidings- en vervangingsvraag - onderscheiden ${ }^{14}$.

Bij de prognoses tot 1992 werd een relatief eenvoudige methode voor het voorspellen van de vervangingsvraag gehanteerd. Willems en De Grip (1993) maakten een uitgebreide analyse van de prognosemethodiek voor de vervangingsvraag. Dit resulteerde in een nieuwe methodiek die bij de hier geëvalueerde prognoses voor het eerst werd gebruikt. Onlangs is deze methodiek nog verder ontwikkeld (Willems, 1996). Deze methodiek is gebruikt bij het opstellen van prognoses tot 2000.

De methodiek van Willems en De Grip (1993) behelst zowel een aanpassing van de definitie van de vervangingsvraag, als een verbeterde prognosetechniek. Vervangingsvraag wordt gedefinieerd als het aantal banen dat in een bepaalde beroepsklasse of voor een bepaald opleidingstype beschikbaar komt voor nieuwkomers in de betreffende categorie. Voor opleidingstypen zijn nieuwkomers in een be-

14. Recentelijk hebben ook het Bureau of Labor Statistics (BLS) voor de Verenigde Staten en het Institute for Employment Research (IER) voor het Verenigd Koninkrijk hun werkgelegenheidsprognoses uitgebreid met prognoses van de vervangingsvraag naar respectievelijk beroep en opleiding. 
paalde categorie in principe ook nieuwkomers op de arbeidsmarkt ${ }^{15}$. Voor beroepsklassen kan er echter ook sprake zijn van nieuwkomers als mensen van beroep veranderen. De vervangingsvraag per beroepsklasse bevat daardoor ook de beroepsmobiliteit.

Een tweede belangrijk aspect met betrekking tot de definitie van vervangingsvraag is dat alleen gekeken wordt naar het vertrek van werkenden voor zover hun plaatsen weer worden opgevuld. Dit impliceert dat bij een krimpende vraag de vervangingsvraag lager zal zijn dan de uitstroom van werkenden. Omdat krimpende werkgelegenheid in een beroepsklasse niet samen hoeft te gaan met een teruglopende vraag naar mensen met een bepaalde opleidingsachtergrond, ontstaan hier naast de genoemde beroepenmobiliteit nog verdere verschillen tussen de vervangingsvraag per beroepsklasse en opleidingstype.

Omdat vervangingsvraag voortkomt uit stromen op de arbeidsmarkt, zouden voor het vaststellen van de vervangingsvraag het beste stroomcijfers gehanteerd kunnen worden. Zulke stroomcijfers zijn echter niet beschikbaar op een aggregatieniveau dat nodig is voor het informatiesysteem. Willems en De Grip (1993) formuleerden daarom een methodiek die op basis van een vergelijking van standcijfers tussen twee jaren, een indicatie geeft van de stromen die tussentijds plaats hebben gevonden. Door de standcijfers per geslacht op te splitsen in leeftijdsgroepen, kan per leeftijdscategorie de netto in- of uitstroom worden vastgesteld. De uitstroomcoëfficiënten zoals ze zijn vastgesteld voor de meetperiode worden vervolgens geprojecteerd op de leeftijdsverdeling in het basisjaar, om zo een prognose te kunnen maken van de uitstroom in de komende jaren. Deze prognose wordt overigens nog gecorrigeerd voor de verwachte veranderingen in de arbeidsparticipatie per geslacht/leeftijdcohort. Hierbij wordt overigens een prognose voor de gehele beroepsbevolking opgelegd aan iedere afzonderlijke categorie. Er wordt dus geen rekening gehouden met de mogelijkheid dat bijvoorbeeld een toenemende participatie van vrouwen zich met name bij bepaalde opleidingstypen manifesteert. Naast deze participatiecorrectie vindt ook een vergelijkbare correctie plaats voor de conjuncturele situatie in de analyseperiode.

Bij de prognoses die voor de periode 1985-1992 werden opgesteld werd feitelijk een voorspelling gemaakt van wat thans uitstroom van werkenden wordt genoemd. Voor de beroepsklassen werd hiervoor reeds gebruik gemaakt van een methode die ook op de vergelijking van geslachts/leeftijdsgroepen was gebaseerd. Voor opleidingstypen werd bij gebrek aan de benodigde data het percentage werkenden boven 55

15. Afgezien van degenen die door bij- of omscholing bij een ander opleidingstype worden ingedeeld. 
jaar als indicator voor de vervangingsvraag gebruikt. De nieuwe methodiek zal daardoor waarschijnlijk met name de vervangingsvraag van vrouwen beter voorspellen.

De cohortmethode die werd gebruikt kent een drietal mogelijke problemen. Dit betreft ten eerste de meetonzekerheid. Omdat de methode gebaseerd is op de vergelijking van twee standcijfers, die door de opsplitsing in gelachts- en leeftijdsgroepen veelal betrekking hebben op kleine groepen, is de invloed van de steekproefonzekerheid zeer groot. Dit probleem kan op een drietal wijzen worden ondervangen. De eenvoudigste aanpassing betreft een plausibiliteitstoets. Clements (1995) laat zien dat het oordeel van een deskundige vaak een gunstige invloed heeft bij onzekere prognosetechnieken. Destijds is echter juist besloten om de vervangingsvraagprognoses zo min mogelijk bij te stellen, mede omdat er toentertijd geen inzicht was in de onderliggende uitstroompatronen voor de verschillende geslacht/leeftijdsgroepen voor een bepaald beroep of opleidingstype. Later is bij de prognoses tot 1998 vaker ingegrepen bij minder plausibele prognose-uitkomsten, terwijl bij de prognoses tot 2000 zelfs de plausibiliteit van de afzonderlijke parameters is getoetst. Een tweede mogelijke aanpak van het probleem van de meetonzekerheid is het vergelijken van meerdere waarnemingsjaren, in plaats van de standcijfers van slechts twee jaren. Destijds was dit vanwege datagebrek nog niet goed mogelijk. Bij de latere prognose tot 1998 en tot 2000 is wel van deze mogelijkheid om meetfouten tegen elkaar weg te laten vallen gebruik gemaakt. Een derde mogelijke aanpak is om in het econometrisch model expliciet met meetfouten rekening te houden. In Willems (1996) is een methode ontwikkeld, die is gebaseerd op een random-coëfficiëntenmodel, dat naarmate een stroomcoëfficiënt minder nauwkeurig wordt gemeten, sterker terugvalt op de gemiddelde coëfficiënt voor de betreffende groep bij alle beroepsklassen of alle opleidingstypen.

Een tweede probleem bij het voorspellen van de vervangingsvraag betreft de samenhang tussen uitstroom en uitbreidingsvraag. Als er bij een bepaalde beroepsklasse sprake is van krimpende werkgelegenheid, dan kan deze krimp gerealiseerd worden door een verhoogde uitstroom van zittend personeel of door een verlaagde instroom van nieuwkomers. Door de prognoses te baseren op vervangingsvraag wordt impliciet verondersteld dat de aanpassing bij een krimpende werkgelegenheid plaatsvindt door een verhoogde uitstroom van werkenden, waarvan nieuwkomers per saldo geen hinder ondervinden. In het vorige evaluatierapport bleek deze aanpak dichter bij de werkelijkheid te liggen dan de omgekeerde veronderstelling dat krimp volledig ten koste gaat van nieuwkomers. Uit deze analyse bleek echter ook dat een gedeeltelijke correctie voor krimpende werkgelegenheid de prognoses verder zou kunnen verbeteren. Verder zou de relatie tussen uitbreidingsvraag en vervangingsvraag kunnen variëren per opleidingstype of beroepsklasse. Dit is tot nog toe niet onderzocht. 
Een derde probleem met de gebruikte methode voor het voorspellen van de vervangingsvraag is dat per onderscheiden cohort alleen het saldo van in- en uitstroom wordt waargenomen. Met name bij beroepsklassen of opleidingstypen waar wel veel sprake is van herintreding, kan door simultane in- en uitstroom in een bepaalde leeftijdsgroep deze netto-stroom de bruto-uitstroom sterk onderschatten. Dit probleem is echter inherent aan de beschikbare data. De enige oplossing is het verder opsplitsen van de onderscheiden groepen. Dit leidt echter tot een verhoging van het meetonzekerheidprobleem. Belangrijke vooruitgang op dit punt kan pas verwacht worden als de zogenaamde retrospectieve vraag in de EBB beschikbaar komt, waarmee de EBB in principe ook stroomcijfers oplevert.

\subsection{Empirische analyse vervangingsvraagprognoses per beroepsklasse}

Bij de evaluatie van de vervangingsvraagprognoses doet zich het probleem voor dat cijfers over de feitelijke vervangingsvraag gedurende de periode 1989-1994 ontbreken. Daarom is deze feitelijke vervangingsvraag gereconstrueerd. Evenals de prognose is hierbij gebruik gemaakt van de zogenaamde netto-methode, waarbij gelijktijdige in- en uitstroom niet wordt waargenomen. Evenals bij de evaluatie van de uitbreidingsvraagprognoses wordt de kwaliteit van de prognoses vergeleken met een referentieprognose. Zoals reeds werd aangegeven in paragraaf 2.2 kan in dit geval niet de SAB-prognose als referentie fungeren. Daarom is, evenals in de vorige evaluatiestudie, gebruik gemaakt van de gemiddelde voorspelde vervangingsvraag, ditmaal uitgedrukt als percentage van de werkgelegenheid in 1989.

Tabel 4.1 geeft een overzicht van de prognose, de realisatie en de voorspelfout per beroepsklasse. Tevens wordt het verlies en de referentieprognose en het verlies gepresenteerd. De tabel geeft een divers beeld te zien. Er is zowel sprake van overen onderschattingen van de vervangingsvraag, hoewel de onderschattingen enigszins de overhand lijken te hebben. Deze diversiteit betekent dat is er geen duidelijk patroon waar te nemen valt in de mate waarin de ontwikkelingen in de mobiliteit destijds goed zijn onderkend. Dezelfde conclusie kan getrokken worden wanneer gekeken wordt naar die beroepsklasse die relatief de grootste voorspel-outen (het grootste verlies) vertonen. Bij twee van de vijf grootste uitschieters is er sprake van een te hoge voorspelling van de vervangingsvraag: de patroonmakers, naaiers en zeilmakers en de vissers en jachtopzieners. Daarentegen is er bij de andere drie grootste uitschieters sprake van een te laag voorspelde vervangings-raag: de werktuigbouwkundigen, de monteurs energievoor-ziening en de dierenarts-en en diergeneeskundigen. Opvallend hierbij is dat het om relatief kleine beroepsklassen gaat. Dit wordt waarschijnlijk veroorzaakt doordat bij deze kleinere beroepsklassen de meetfouten als gevolg van steekproef-onzekerheid relatief groot zijn. Overigens geldt bij de kleinere beroepsklassen dat zowel voor het opstellen van de prognoses, als bij het construeren van de realisaties relatief grote meetfouten worden gemaakt. 


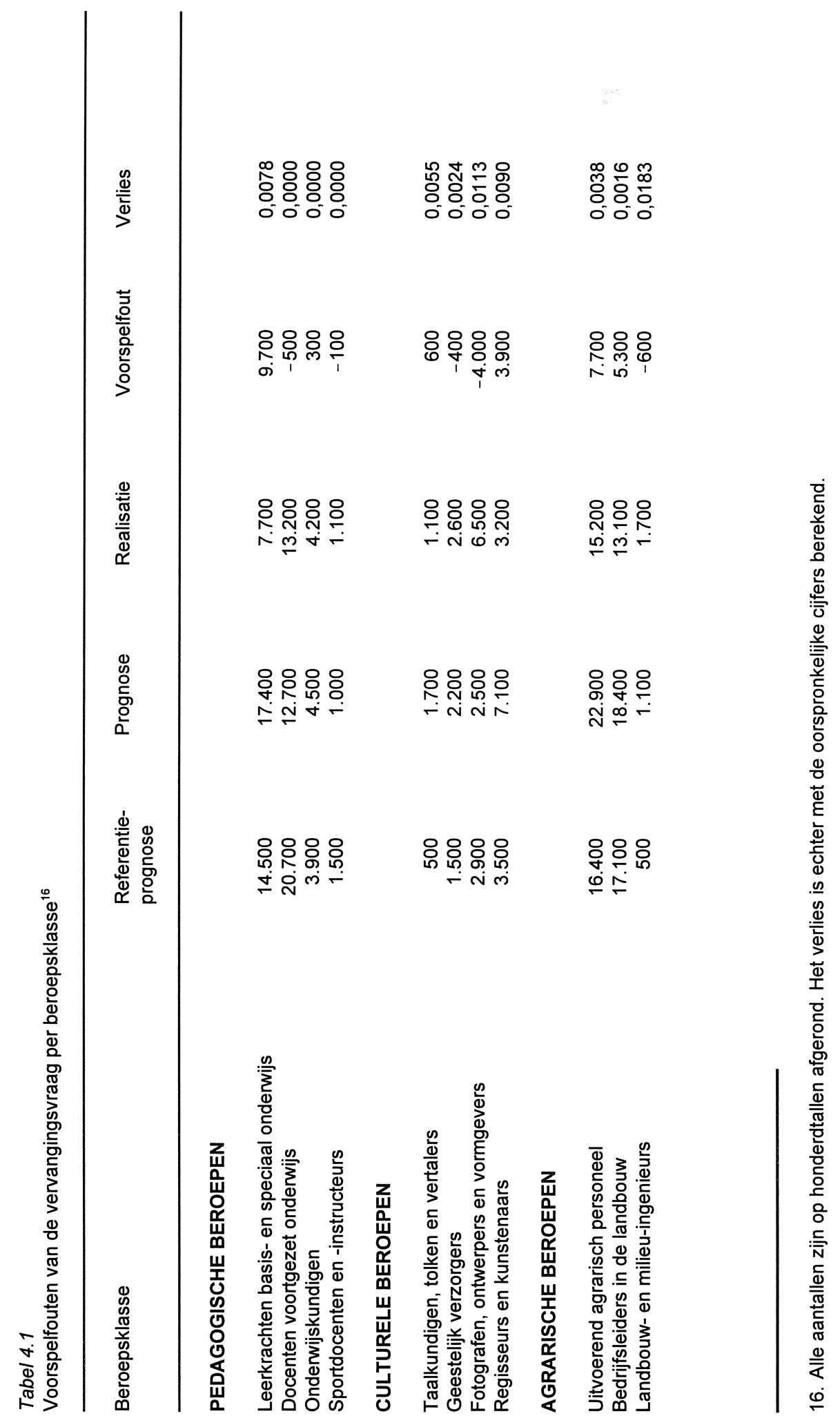




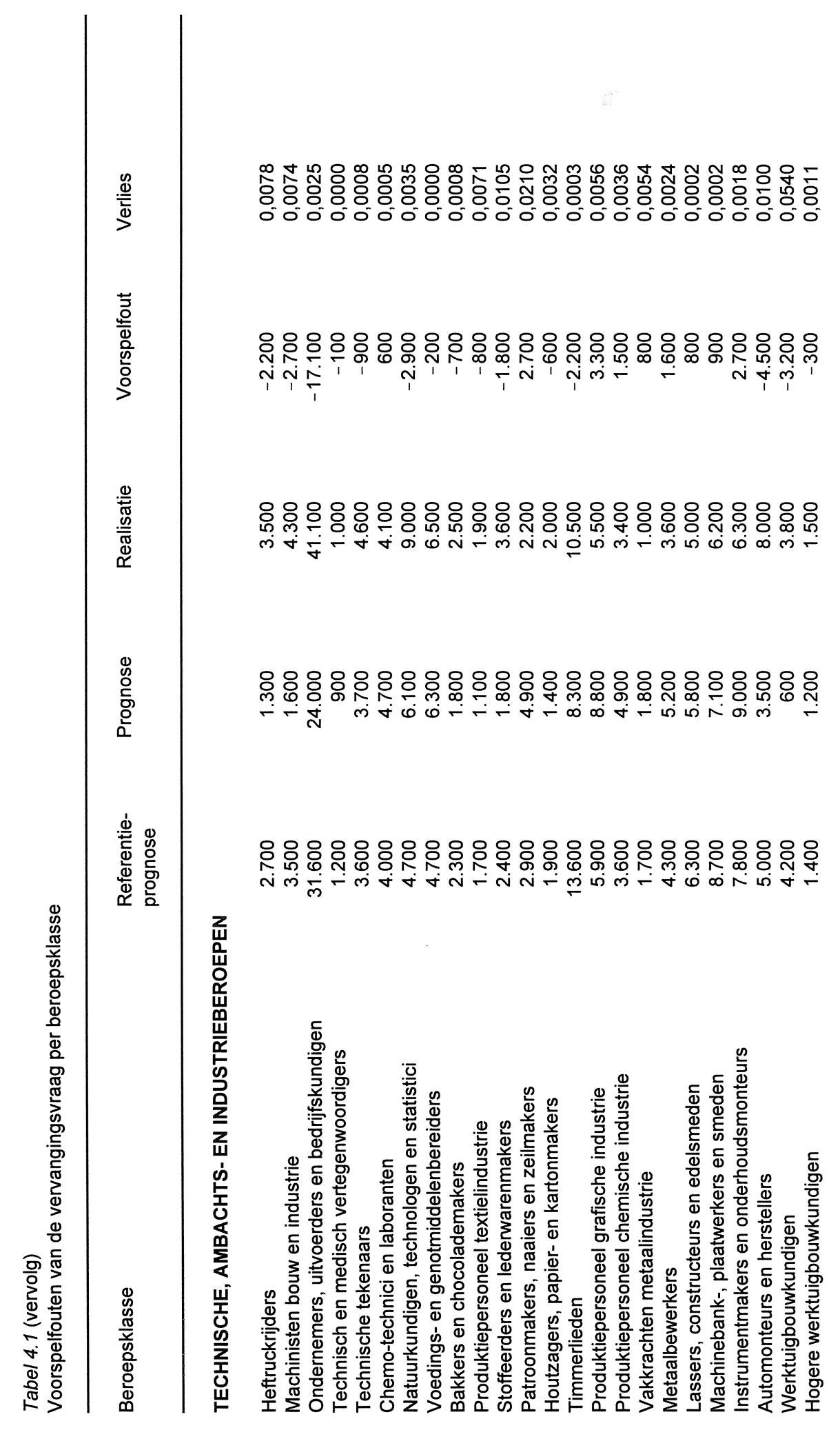




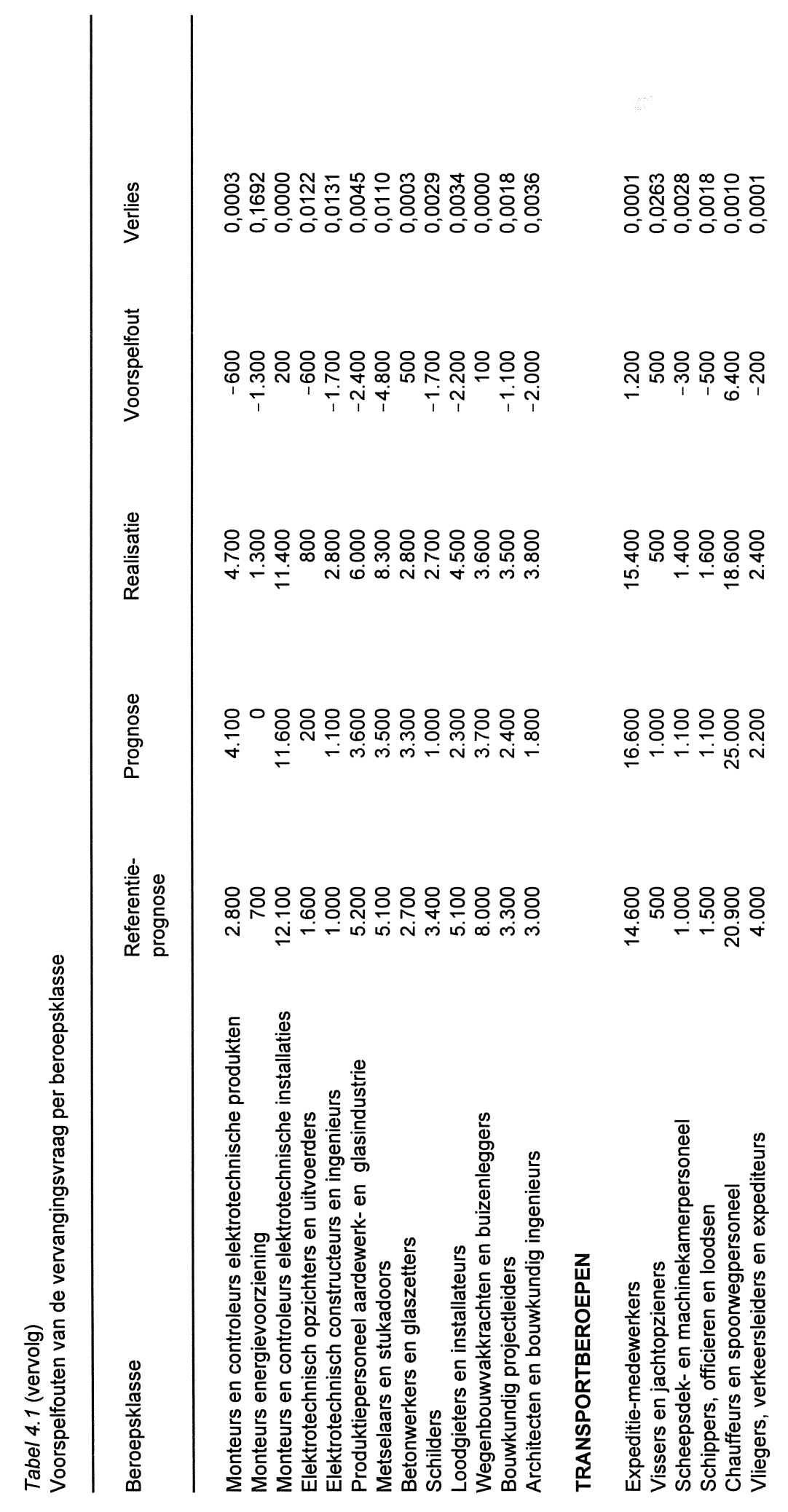




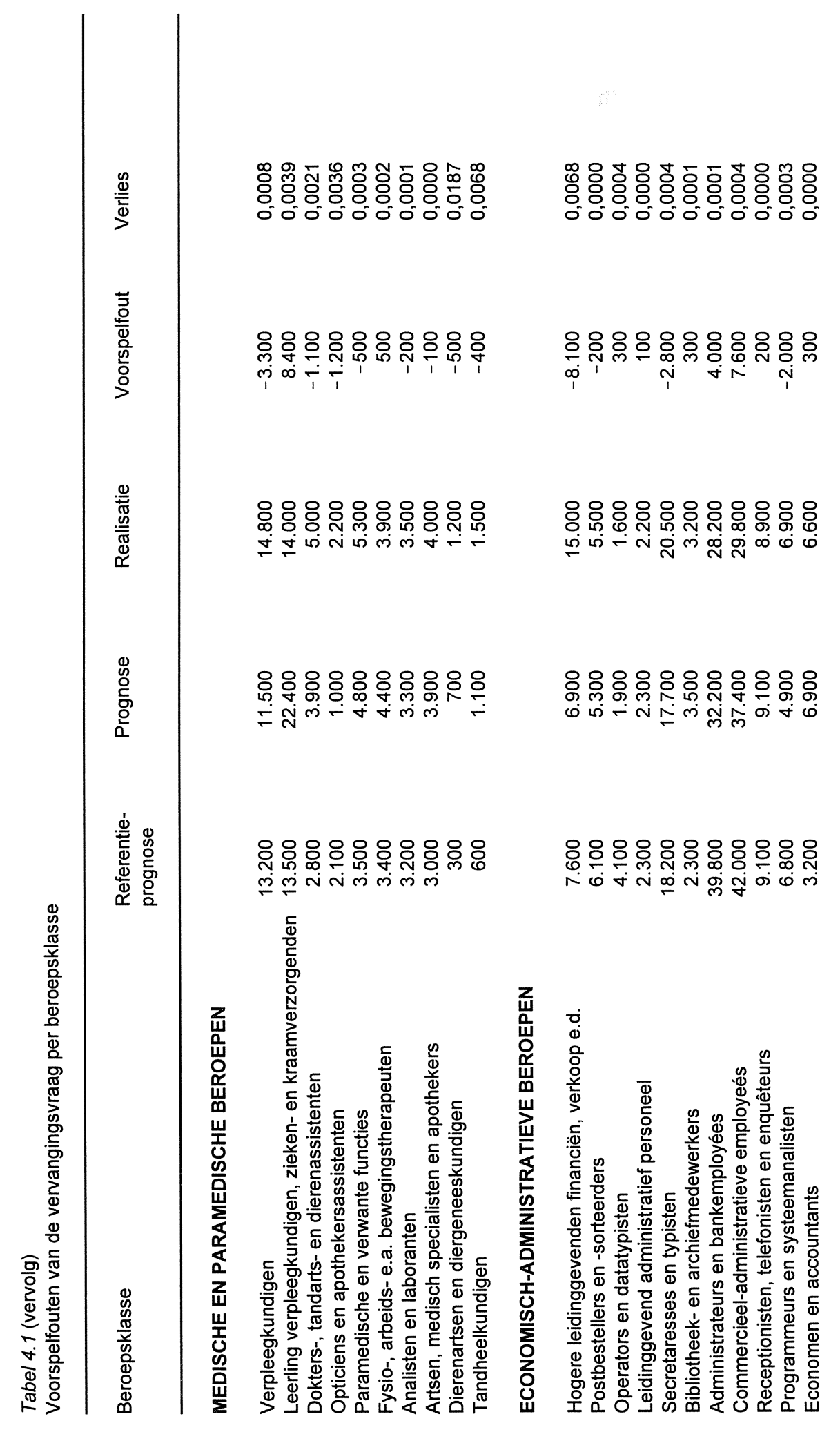




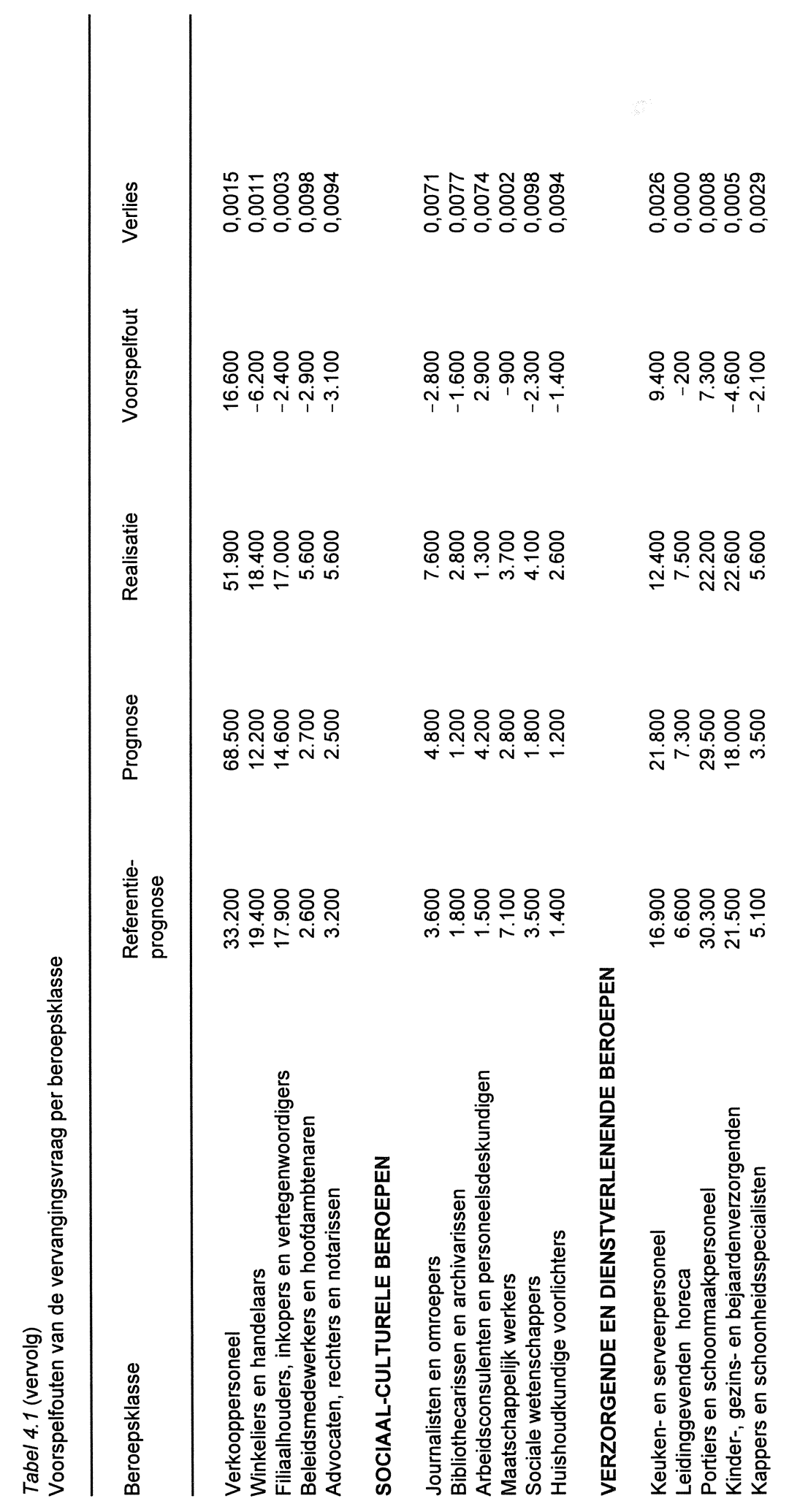




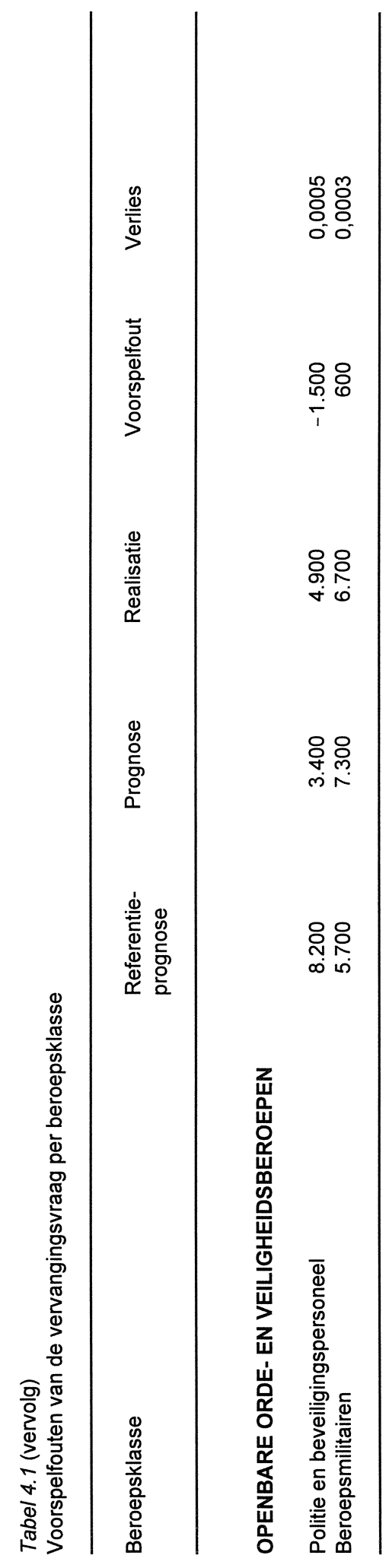


Vergeleken met de vorige evaluatie blijkt het aandeel van de beroepen waarbij er sprake is van een onderschatting duidelijk te zijn afgenomen. Bleek in 1992 dat er bij 71 van de 79 beroepen (90\%) sprake was van onderschatting, nu is dat nog slechts in 58 van de 93 beroepen (62\%) het geval. Wanneer gekeken wordt naar de uitschieters blijkt dat er ditmaal beroepen van een geheel ander karakter negatief uitspringen vergeleken met de prognoses die betrekking hadden op de periode 1988-1992. Er blijkt dus geen sprake te zijn van een vast patroon in de voorspelfouten.

Tabel 4.2

Totaaloverzicht voorspelkwaliteit vervangingsvraagprognoses per beroepsklasse

\begin{tabular}{|c|c|c|c|}
\hline Methode & $\begin{array}{l}\text { Gem. verlies } \\
\text { prognose }\end{array}$ & $\begin{array}{l}\text { Gem. verlies } \\
\text { referentie }\end{array}$ & Score \\
\hline
\end{tabular}

Prognoses tot 1994

Vervangingsvraag

$\begin{array}{llrr}\text { Absoluut } & 0,0022 & 0,0016 & 1,38 \\ \text { Relatief } & 0,0022 & 0,0016 & 1,39 \\ \text { Uitstroom } & & & \\ & & & 1,03 \\ \text { Absoluut } & 0,0100 & 0,0097 & 1,12 \\ \text { Relatief } & 0,0085 & 0,0076 & \end{array}$

Vervangingsvraag krimp versus groei (relatief)

$\begin{array}{llll}\text { Krimpberoepen } & 0,0031 & 0,0016 & 1,87\end{array}$

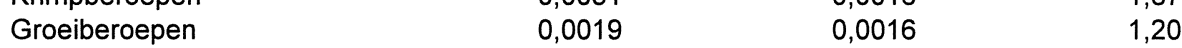

Vervangingsvraag per kwalitatieve typering prognose (relatief)

$\begin{array}{llrr}\text { Erg laag } & 0,0047 & 0,0018 & 2,59 \\ \text { Laag } & 0,0025 & 0,0019 & 1,37 \\ \text { Gemiddeld } & 0,0010 & 0,0009 & 1,17 \\ \text { Hoog } & 0,0034 & 0,0031 & 1,09 \\ \text { Erg hoog } & 0,0061 & 0,0023 & 2,64\end{array}$

Prognoses tot 1992

Uitstroom

Relatief

0,0180

0,0181

1,00

Tabel 4.2 toont de algehele voorspelkwaliteit van de vervangingsvraagprognoses. Aangezien er sprake is geweest van een methodiekverandering van uitstroom- naar 
vervangingsvraagprognoses, worden de voorspellingen zowel met de gerealiseerde vervangingsvraag als met de gerealiseerde uitstroom vergeleken.

In het vorige evaluatierapport werd uiteengezet dat met de huidige prognosemethodiek impliciet wordt aangenomen dat de vervangingsvraag niet afhangt van de mate van krimp in een beroepsklasse. Dit betekent dat, ondanks een dalende werkgelegenheid, werkgevers in gelijke mate nieuwkomers blijven werven. De krimp gaat ten koste van de oudere werknemers. Omgekeerd zou verondersteld kunnen worden dat juist de uitstroomcoëfficiënten constant zijn. In dat geval zou een krimpende werkgelegenheid opgevangen worden door minder nieuwkomers aan te nemen. In het vorige evaluatierapport werd getoond dat de veronderstelling van een constante vervangingsvraag beter de in- en uitstroompatronen blijkt te verklaren dan de veronderstelling van een constante uitstroom van werkenden. De werkelijkheid lijkt overigens tussen deze twee extremen in te liggen.

Ook nu lijken de resultaten in dezelfde richting te wijzen. Uit tabel 4.2 blijkt dat het gemiddeld verlies bij de vervangingsvraagprognoses lager is dan bij de uitstroomprognoses. Dit geldt ook voor de referentieprognose. De vervangingsvraag varieert dus beduidend minder dan de uitstroom van werkenden. Vergeleken met de referentieprognose scoort de uitstroom echter beter. Dit betekent dat de prognoses voor de vervangingsvraag een opmerkelijk goede voorspelling van de uitstroom geven. Dit kan alleen worden verklaard door het feit dat de vervangingsvraag minder variatie vertoont dan de uitstroom. Zoals de tabel laat zien, zijn deze resultaten vergelijkbaar met de eerdere prognoses tot 1992. De overstap van het voorspellen van de uitstroom naar het voorspellen van de vervangingsvraag heeft derhalve geresulteerd in een additionele verbetering van de prognosekwaliteit die niet direct in de cijfers tot uitdrukking komt. De voorspelfout reduceert hierdoor met ongeveer $80 \%$. De uitsplitsing in de tabel naar het gemiddeld verlies voor respectievelijk krimp- en groeiberoepen bevestigt echter dat ook in de methodiek die gebaseerd is op vervangingsvraag in plaats van de uitstroom van werkenden, de krimpberoepen relatief moeilijk voorspelbaar zijn.

Uit de achterliggende cijfers blijkt dat met name de prognoses met betrekking tot de culturele beroepen een relatief groot gemiddeld verlies opleveren. Wanneer naar de kwaliteitsscore gekeken wordt, dan vallen de technische en verzorgende beroepen in negatieve zin op. Gezien de problemen bij het voorspellen van de vervangingsvraag voor krimpende beroepen is dit, met name voor de technische beroepen geen verrassende uitkomst. Tabel 3.4 liet reeds zien dat veel beroepsklassen in deze beroepscategorie te kampen hebben met een krimpende werkgelegenheid. Positieve uitschieters zijn, zowel wat betreft het gemiddeld verlies als de kwaliteitsscore, de economisch-administratieve beroepen en de beroepen in de openbare orde en veiligheidssector. Ook pedagogische en de medische beroepen 
scoren in dit opzicht relatief goed. In het vorige evaluatierapport werd geconcludeerd dat vooral die beroepen waarin veel vrouwen werken relatief goed scoren in vergelijking met de referentieprognose. Vanwege de sterk afwijkende uitstroompatronen bij vrouwen is de referentieprognose hier relatief slecht. Deze conclusie kan ook nu getrokken worden. Met name in economisch-administratieve en medische beroepen werken immers relatief veel vrouwen. Eenzelfde argument geldt voor beroepen met een relatief jong personeelsbestand, zoals de beroepen in de openbare orde. Ook hier zal de referentieprognose relatief slecht voorspellen.

\section{Verklaring van voorspelfouten}

Om meer inzicht te verkrijgen in de kwaliteit van de voorspellingen is getracht de standaarddeviatie van de absolute voorspelfout in de vervangingsvraag te relateren aan enkele verklarende variabelen. Het resultaat is weergegeven in tabel 4.3.

\section{Tabel 4.3}

Verklaring van voorspelfouten van de relatieve prognose

\begin{tabular}{lcc}
\hline Variabele & Parameter & T-waarde \\
\hline & & \\
Constante & 1,30 & 1,47 \\
Schaal & 0,59 & $7,00^{* \star}$ \\
Spreidingsindicator & 0,09 & 0,31 \\
Conjunctuurindicator & $-0,02$ & $-0,14$ \\
Verandering uitbreidingsvraag & 0,15 & 0,07 \\
Percentage vrouwen & $-0,02$ & $-0,04$ \\
Onderschattingscoëfficiënt & $-0,66$ & $-6,83^{* *}$ \\
\end{tabular}

* significant bij betrouwbaarheid van $90 \%$

** signifcant bij betrouwbaarheid van $95 \%$

Evenals bij de uitbreidingsvraagprognoses is een schaalvariabele opgenomen. Dit schaaleffect is vergelijkbaar met de bevindingen bij de bedrijfssector- en de uitbreidingsvraagprognoses per beroepsklasse. De parameter is kleiner dan één, hetgeen impliceert dat grote beroepsklassen in aantallen slechter, maar in procenten beter voorspeld worden dan de kleine beroepsklassen. In tegenstelling tot de analyse van de voorspelfouten bij de uitbreidingsvraag, vertonen de risico-indicatoren geen significante samenhang met de voorspelfout. Ten slotte is het absolute verschil tussen de uitbreidingsvraag in de prognose en de observatie-periode als verklarende variabele opgenomen. Dit verschil blijkt geen significante invloed te hebben op de omvang van de voorspelfout. Wanneer deze resultaten vergeleken worden met de voorgaande evaluatie, dan blijkt het schaaleffect van vergelijkbare omvang te zijn. De risico-indicatoren bleken echter toentertijd wel een significante invloed op te voorspelfout te hebben. Waarschijnlijk hangt dit verschil samen met de 
overgang van uitstroom- naar vervangingsvraagprognoses. Toentertijd bleken immers de conjunctuurgevoelige beroepsklassen een hoge standaarddeviatie van de voorspelfout te kennen. Met name bij de conjunctuurgevoelige beroepsklassen kunnen schommelingen in de uitstroom groot zijn, terwijl de vervangingsvraag opnieuw veel stabieler blijkt te zijn. Ook de absolute verandering in de uitbreidingsvraag is thans niet meer significant. Gezien het feit dat, in tegenstelling tot de uitstroom, de vervangingsvraag niet beïnvloed wordt door de omvang van de uitbreidingsvraag, is ook deze bevinding in overeenstemming met de verwachte verbetering van de prognoseskwaliteit vanwege overgang naar vervangingsvraagprognoses.

Tevens is in bovenstaande tabel weergeven in hoeverre er sprake is van over- of onderschatting van de waargenomen veranderingen. Omdat bij de vervangingsvraag de referentieprognose niet gelijk is aan de situatie in het verleden (Same As Before), wordt in dit geval de onder- of overschatting van afwijkingen van het gemiddelde geanalyseerd. De tabel laat zien dat de overschattingscoëfficiënt $-0,66$ bedraagt. Dit betekent dat er bij de vervangingsvraag per beroepsklasse sprake is van een duidelijke overschatting van afwijkingen. Deze bevinding impliceert dat de voorspelling relatief veel ruis bevat. De overschattingscoëfficiënt die thans gevonden wordt is in overeenstemming met hetgeen bij de vorige evaluatie waargenomen werd. Een voorzichtigere voorspelling zou een verbetering betekenen. Aan de geregistreerde verschillen wordt te veel betekenis toegekend. Deels zijn zij immers het gevolg van meetfouten. De nieuwe methodiek houdt echter rekening met deze steekproefonzekerheid. Verder kan de overschatting van de veranderingen ook een gevolg zijn van het feit dat de bij het opstellen van prognoses voor de periode 1989-1994 beschikbare data tamelijk verouderd waren ${ }^{17}$ waardoor er nog oude uitstroompatronen werden gehanteerd.

\section{Kwalitatieve typeringen}

Evenals bij de uitbreidingsvraag is bij de vervangingsvraag per beroepsklasse een kwalitatieve typering gemaakt. De indeling van de kwalitatieve typeringen is als volgt:

\begin{tabular}{|c|c|c|c|c|c|}
\hline & & VBK & $\leq$ & $5 \%$ & erg laag \\
\hline $5 \%$ & $<$ & VBK & $\leq$ & $9 \%$ & laag \\
\hline $9 \%$ & $<$ & VBK & $\leq$ & $14 \%$ & gemiddeld \\
\hline $14 \%$ & $<$ & VBK & $\leq$ & $18 \%$ & hoog \\
\hline $18 \%$ & $<$ & VBK & & & erg hoog \\
\hline
\end{tabular}

17. De gebruikte data hadden betrekking op de jaren 1981-1985. 
waarbij VBK staat voor vervangingsvraag per beroepsklasse (Dekker e.a., 1992).

Tabel 4.4 toont in hoeverre de kwalitatieve typering van de relatieve voorspelling overeenkomt met de gerealiseerde typering. Uit de tabel blijkt dat voor 30 van de 93 beroepsklassen de voorspelde typering overeenkomt met de realisatie, terwijl voor 41 beroepsklassen geldt dat de voorspelde kwalitatieve typering slechts één typeringscategorie te hoog of te laag is. Dit betekent dat er in totaal in $76 \%$ van de gevallen een geheel of bijna juiste typering gemaakt is. Dit is een duidelijke vooruitgang ten opzichte van de uitstroomprognoses voor 1992 die in $62 \%$ van de gevallen geheel of bijna juist bleken te zijn. Voor de typeringen die exact juist zijn is een vooruitgang van 29 naar $32 \%$ geboekt.

Tabel 4.4

Typeringen van de uitbreidingsvraag per beroepsklasse (relatief)

\begin{tabular}{|c|c|c|c|c|c|c|}
\hline \multirow[b]{2}{*}{ Realisatie } & \multirow[b]{2}{*}{ erg laag } & \multirow[b]{2}{*}{ laag } & \multicolumn{2}{|l|}{ Prognose } & \multirow[b]{2}{*}{ erg hoog } & \multirow[b]{2}{*}{ totaal } \\
\hline & & & gemiddeld & hoog & & \\
\hline Erg laag & 0 & 1 & 0 & 0 & 0 & 1 \\
\hline Laag & 3 & 4 & 5 & 2 & 1 & 15 \\
\hline Gemiddeld & 2 & 13 & 18 & 8 & 4 & 45 \\
\hline Hoog & 0 & 4 & 4 & 2 & 1 & 11 \\
\hline Erg hoog & 1 & 2 & 6 & 6 & 6 & 21 \\
\hline Totaal & 6 & 24 & 33 & 18 & 12 & 93 \\
\hline
\end{tabular}

Ook het aantal beroepsklassen dat een typering heeft gekregen die de verkeerde richting aangeeft, is aanzienlijk afgenomen. Gold dit voor de uitstroomprognoses betreffende 1992 nog voor 37\% van de beroepsklassen, thans is dat nog slechts voor $11 \%$ van de beroepsklassen het geval. Voor zeven beroepsklassen blijkt de vervangingsvraag hoog of erg hoog te zijn, terwijl werd voorspeld dat de vervangingsvraag laag of erg laag zou zijn. In drie gevallen blijkt het omgekeerde het geval. De voorspelde vervangingsvraag was hoog of erg hoog, terwijl in werkelijkheid de vervangingsvraag laag of erg laag is geweest. De tabel toont aan dat er vier extreme typeerfouten aangewezen kunnen worden. Voor de monteurs energievoorziening blijkt de vervangingsvraag erg hoog te zijn geweest, terwijl de voorspelde vervangingsvraag erg laag was. De automonteurs en herstellers en de metselaars en stukadoors werden daarentegen gekenmerkt door een erg hoge vervangingsvraag, terwijl de verwachting was dat de vervangingsvraag laag zou zijn. Voor de patroonmakers, naaiers en zeilmakers tenslotte, geldt dat de vervangingsvraag laag is, terwijl deze beroepsklasse bij de voorspelling een typering 'erg hoog' heeft gekregen. 
Evenals bij de uitbreidingsvraag per beroepsklasse is voor de vervangingsvraag per beroepsklasse nader onderzocht hoe de prognoseresultaten zich verhouden tot de prognoses tot 1992. Hierbij is met name gekeken naar het verband tussen voorspelkwaliteit en schaal en de invloed die de overgang van de oude CBSBeroepenindeling naar de nieuwe ROA-classificatie gehad heeft op de prognoseresultaten. Omdat voor 1992 de uitstroom en niet de vervangingsvraag is voorspeld, wordt hiermee niet alleen een vergelijking tussen beide prognoseperiodes, maar ook tussen beide invalshoeken gemaakt. Figuur 4.1 laat opnieuw zien dat de vervangingsvraagprognoses voor de periode 1989-1994 aanmerkelijk lagere voorspelfouten hebben dan de eerdere uitstroomprognoses tot 1992. Dit verschil geldt ook voor de referentieprognose.

Figuur 4.1

Verwachte standaarddeviatie prognoses en referentieprognoses, 1992 en 1994.

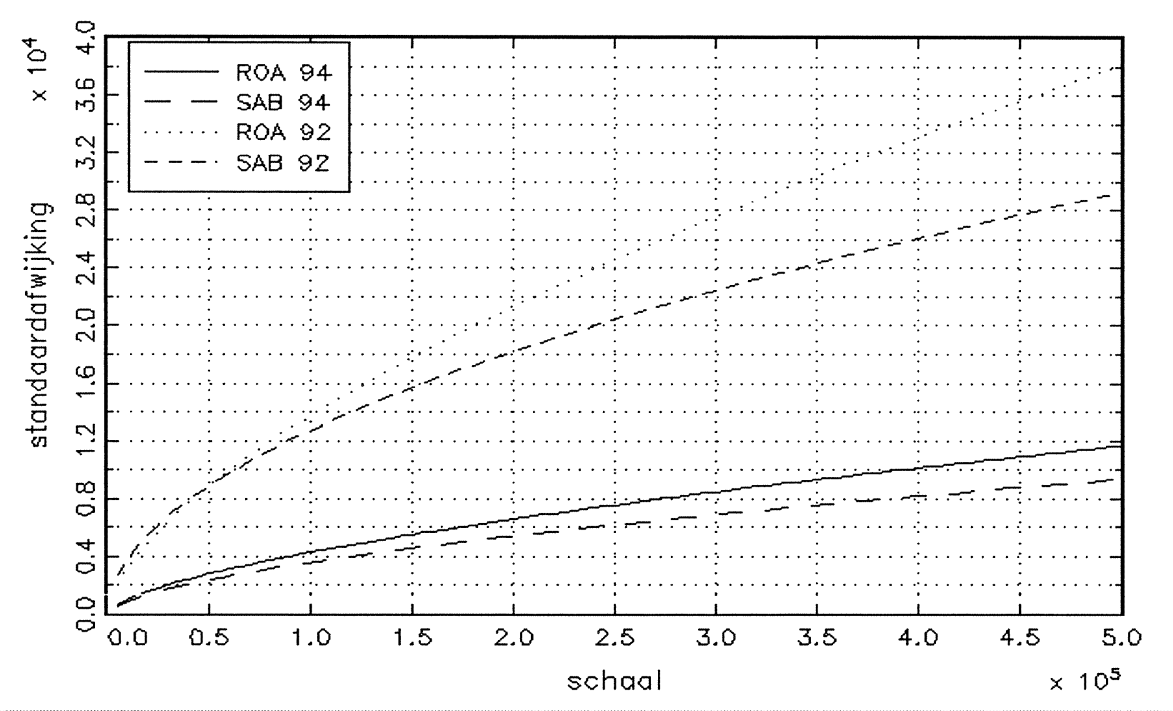

Figuur 4.2 laat zien dat de uitstroomprognoses tot 1992 met name bij de kleinere beroepsklassen betrekkelijk goed waren, in vergelijking met de referentieprognose voor die periode. Omdat bij de overgang van uitstroomprognoses naar vervangingsvraagprognoses de referentieprognose sterker verbeterde dan de feitelijk gehanteerde voorspellingen, verslechtert de score bij de vervangingsvraagprognoses tot 1994, met name voor deze kleinere beroepsklassen. De enige verbetering van de score ten opzichte van de uitstroomprognoses tot 1992 wordt geboekt bij de grotere beroepsklassen. Dit ligt voor de hand omdat bij de vervangingsvraagprognoses de samenhang met de uitbreidingsvraag nauwelijks nog een verstorende invloed heeft. 
Hierdoor domineert de fout als gevolg van meetonzekerheden die relatief het kleinst zijn bij de grotere beroepsklassen.

\section{Figuur 4.2}

Verwachte standaarddeviatie prognoses ten opzichte van referentieprognose, 1992 en 1994.

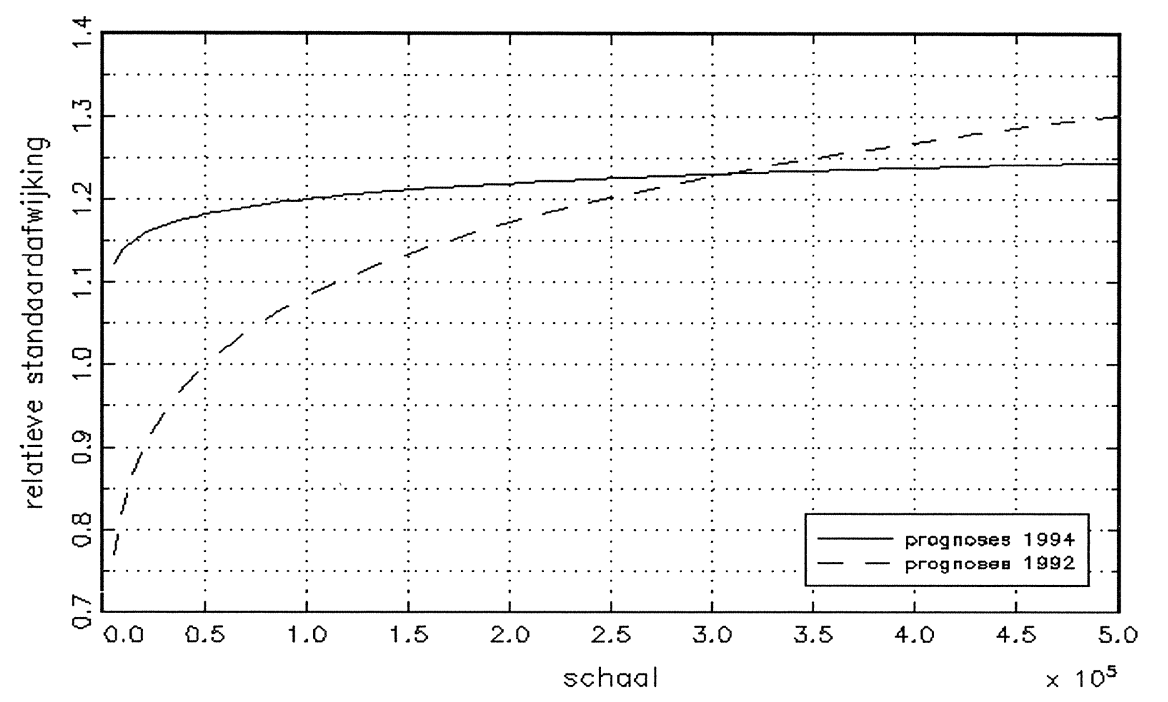

Tabel 4.5 gaat in op het verband tussen de gehanteerde beroepenclassificatie en het verwachte gemiddeld verlies. Evenals bij de uitbreidingsvraag per beroepsklasse blijkt dat zowel de prognose tot 1992 als de prognose tot 1994 het laagste verwachte gemiddeld verlies kennen bij de oude classificatie. Dit wordt veroorzaakt door de positieve invloed die enkele zeer grote beroepsklassen in de oude classificatie hebben op het totale gemiddelde verlies. Ook bij de referentieprognoses wordt een vergelijkbaar effect gevonden (Zie tabel 4.6). Voor 1994 is, zoals tabel 4.7 laat zien, de achteruitgang in verwacht gemiddeld verlies voor de referentieprognose echter evenredig aan de achteruitgang bij de prognoses. Voor 1992 zou de verwachte score echter lager zijn geweest bij de nieuwe beroepenclassificatie.

\section{Tabel 4.5}

De relatie tussen het verwachte gemiddeld verlies de prognoses en de gehanteerde classificatie

1992
1994 
Tabel 4.6

De relatie tussen het verwachte gemiddeld verlies van $S A B$ en de gehanteerde classificatie

\begin{tabular}{lcc}
\hline & 1992 & 1994 \\
\hline & & \\
Classificatie 92 & 0,0181 & 0,0013 \\
Classificatie 94 & 0,0228 & 0,0016 \\
\hline
\end{tabular}

Tabel 4.7

De relatie tussen de score en de gehanteerde classificatie

\begin{tabular}{lcc}
\hline & 1992 & 1994 \\
\hline Classificatie 92 & 1,01 & 1,40 \\
Classificatie 94 & 0,98 & 1,40 \\
\hline
\end{tabular}

\section{Conclusies}

Uit de evaluatie van de vervangingsvraagprognoses per beroepsklasse kunnen de volgende conclusies getrokken worden. De kwaliteit van de prognoses is aanzienlijk toegenomen vergeleken met de prognoses voor 1992. Dit blijkt uit het feit dat het gemiddeld verlies duidelijk is afgenomen. Deze verbetering van de voorspelkwaliteit wordt volledig veroorzaakt door de overstap van het voorspellen van de uitstroom naar het voorspellen van de vervangingsvraag. Toch blijt de kwaliteitsscore van de vervangingsvraagprognoses hoger dan de score van de uitstroom, hoewel het verschil kleiner is geworden. De hoge score blijkt voor een belangrijk deel veroorzaakt te worden door de relatief slechte voorspelkwaliteit van de prognoses voor de beroepsklassen die gekenmerkt worden door een krimpende werkgelegenheid. Ook bij een prognosemethodiek gebaseerd op vervangingsvraag blijft een correctie voor krimpende werkgelegenheid dus gewenst. Verder blijken met name de extreme voorspellingen slecht te zijn geweest. Dit pleit voor een sterkere plausibiliteitstoets dan destijds heeft plaatsgevonden. Daarnaast mag verwacht worden dat de recente introductie van een random-coëfficiënten-model ertoe zal leiden dat de prognoses minder gevoelig worden voor meetfouten, waardoor de betrouwbaarheid verder vergroot zal worden. Tenslotte blijkt, vanwege de sterke reductie van het gemiddeld verlies, de kwaliteit van de kwalitatieve typeringen van de vervangingsvraagprognoses beter te zijn de kwaliteit van de typeringen voor de uitstroomprognoses voor 1992. 


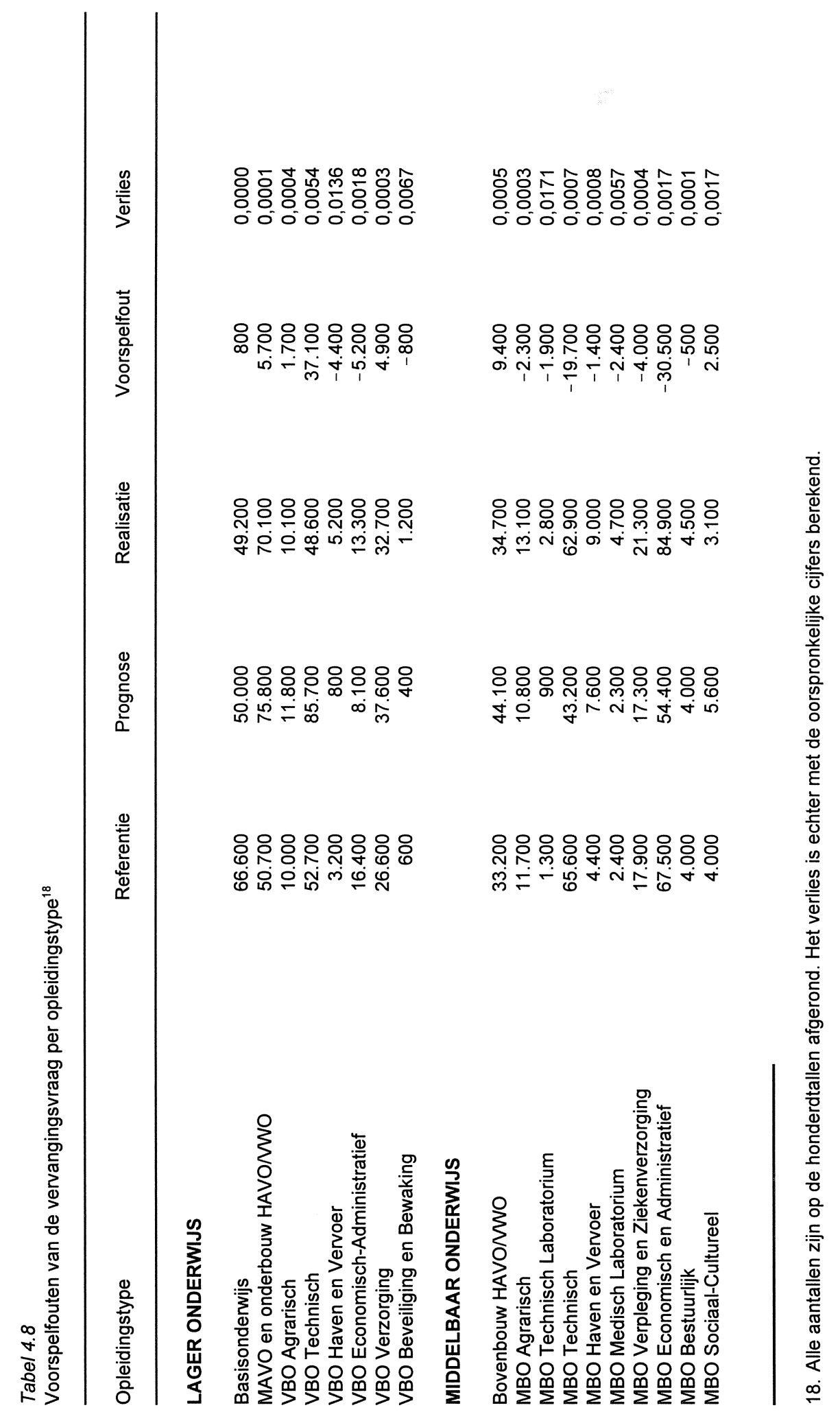




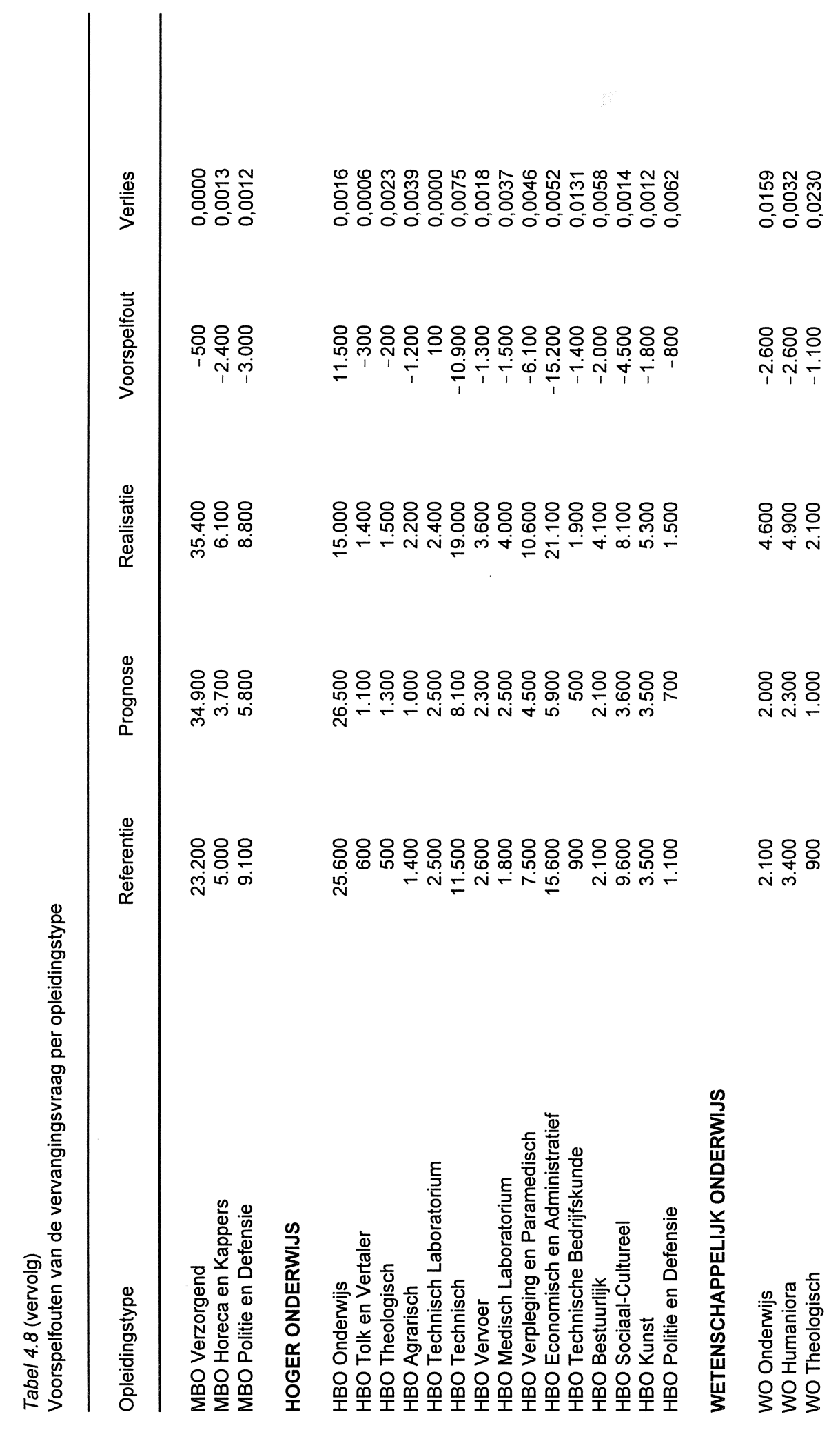




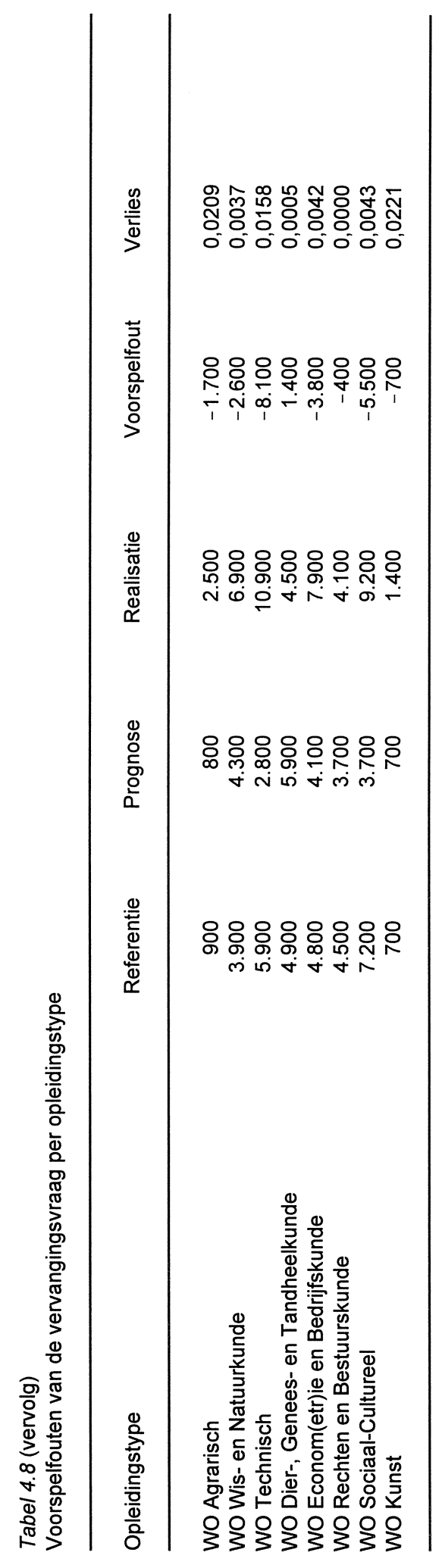




\subsection{Empirische evaluatie vervangingsvraagprognoses per opleidingstype}

Zoals reeds in paragraaf 4.2 beschreven is, heeft bij de vervangingsvraag per opleidingstype een belangrijke methodiekverandering plaatsgevonden. De prognoses voor 1992 waren eenvoudigweg gebaseerd op het aantal werkzame personen van 55 jaar en ouder. De methodiek die gehanteerd is bij de thans geëvalueerde prognoses is identiek aan de bij de vervangingsvraag per beroepsklasse gehanteerde benadering. Bovendien is, net als bij de prognoses betreffende de beroepsklassen, gekozen voor het voorspellen van de daadwerkelijke vervangingsvraag in plaats van de uitstroom.

In tabel 4.8 wordt een overzicht gegeven van de voorspelfouten per opleidingstype. De tabel laat zien dat er over het algemeen sprake is van een onderschatting van de vervangingsvraag. Voor slechts tien van de 47 geëvalueerde opleidingstypen geldt dat de prognose de gerealiseerde vervangingsvraag overtreft. Deze tien opleidingstypen zijn voor een groot deel van laag of middelbaar niveau. Kennelijk is, met name bij de hoger opgeleiden, het aantal mensen dat de arbeidsmarkt heeft verlaten groter geweest dan verwacht. Dat betekent dat de uitstroom op jongere leeftijden de afgelopen tijd aanzienlijk is toegenomen. De relatief oude data (tot 1985) die gebruikt zijn voor het opstellen van de vervangingsvraagprognoses hebben deze voorspelfout daardoor verergerd. Het grootste verlies treedt op bij de opleidingen MBO technisch laboratorium, en de WO-richtingen onderwijs, agrarisch, technisch en kunst. Het gaat in alle vijf gevallen om opleidingstypen waarvoor de feitelijke vervangingsvraag minstens twee keer zo groot is als voorspeld. Deze bevinding bevestigt het beeld dat de prognoses over het algemeen te laag zijn geweest.

Opvallend goed voorspeld zijn het basisonderwijs, MBO verzorgend, HBO technisch laboratorium en WO rechten en bestuurskunde. Het verlies voor deze opleidingstypen is verwaarloosbaar klein. Over het algemeen wordt aangenomen dat voor opleidingstypen waarvan een groot deel van de afgestudeerden vrouw is de vervangingsvraag relatief moeilijk te voorspellen valt. In dat licht is de kwaliteit van de prognose voor het MBO verzorgend een opmerkelijk resultaat.

Tabel 4.9 geeft een overzicht van het gemiddelde verlies van de prognoses van de vervangingsvraag per opleidingstype. Tevens wordt het gemiddeld verlies gepresenteerd wanneer de prognoses geïnterpreteerd worden als uitstroomprognoses. Uit de tabel blijkt dat het gemiddeld verlies beduidend lager is wanneer de prognoses, zoals beoogd, geïnterpreteerd worden als vervangingsvraagprognoses. Dit werd ook bij de vervangingsvraag per beroepsklasse geconstateerd. Deze resultaten bevestigen ook voor opleidingstypen de notie dat het zinvoller is prognoses te genereren van de vervangingsvraag dan van de uitstroom. Tevens valt op dat de 
referentieprognose - dat wil zeggen de gemiddeld voorspelde vervangingsvraag beduidend beter scoort dan de daadwerkelijke prognose. Voor de absolute prognoses is de score 1,85 . Voor de relatieve prognoses is de score zelfs 2,26 . Blijkbaar levert de gehanteerd methodiek gemiddeld genomen een goede prognose op, maar is het moeilijk om de opleidingsspecifieke verschillen goed te voorspellen.

Tabel 4.9

Totaaloverzicht voorspelkwaliteit vervangingsvraagprognoses per opleidingstype

\begin{tabular}{llll}
\hline & $\begin{array}{l}\text { Gem. verlies } \\
\text { prognose }\end{array}$ & $\begin{array}{l}\text { Gem. verlies } \\
\text { referentie }\end{array}$ & Score \\
\hline Prognoses tot 1994 & & & \\
Vervangingsvraag & & & \\
absoluut & & & \\
relatief & 0,0020 & 0,0011 & 1,85 \\
Uitstroom & 0,0022 & 0,0010 & 2,26 \\
absoluut & & & \\
relatief & 0,0101 & 1,26 \\
Vervangingsvraag per kwalitatieve typering (relatief) & 0,0043 & 0,0080 & 2,02 \\
erg laag & 0,0089 & 0,0044 & 8,69 \\
laag & 0,0018 & 0,0005 & 1,42 \\
gemiddeld & 0,0015 & 0,0012 & 1,99 \\
hoog & 0,0011 & 0,0010 & 5,70 \\
erg hoog & 0,0082 & 0,0005 & \\
Prognoses tot 1992 & & 0,0014 & \\
Vervangingsvraag & & & 1,18 \\
relatief & 0,0020 & & \\
\hline & & 0,0017 & \\
\hline
\end{tabular}

Om meer inzicht te verkrijgen in de opvallend hoge score zijn de opleidingstypen onderverdeeld aan de hand van de kwalitatieve typering die zij bij de prognose hebben meegekregen. Uit de tabel blijkt dat met name de erg lage en erg hoge prognoses opnieuw problemen opleveren. Het gemiddeld verlies van de prognose is voor de betreffende opleidingstypen beduidend hoger dan voor de opleidingstypen met een gematigde prognose. Aangezien de kwaliteit van de referentieprognose veel minder varieert, leveren de extreme prognoses een relatief hoge score op. Voor de opleidingstypen waarvan de prognose de typering 'erg laag' heeft gekregen, is deze score het hoogst: 8,69. Voor de prognoses die als typering 'laag' hebben gekregen is de score slechts 1,42 en is het gemiddeld verlies minder dan de helft dan bij de prognoses met als typering 'erg laag'. Dit probleem, dat ook bij de beroepsklassen geconstateerd werd, is reeds eerder onderkend. In de thans 
gehanteerde methodiek worden, zoals reeds is opgemerkt, de minder robuuste extreme prognoses vermeden door het gebruik van een random-coëfficiëntenmodel. Bovendien dient opgemerkt te worden dat bij de vervangingsvraagprognoses naar opleidingstype voor 1994 nauwelijks bijstellingen achteraf hebben plaatsgevonden. Ook ten aanzien van dit aspect is de aanpak inmiddels aangepast. Thans wordt vaker gekozen voor een bijstelling achteraf wanneer het gehanteerd model minder plausibele prognoses oplevert.

Wanneer tenslotte een vergelijking wordt gemaakt met de kwaliteit van de prognoses voor 1992, blijkt het gemiddeld verlies van vergelijkbare omvang te zijn. Het gemiddeld verlies voor de relatieve prognoses was voor 1992 0,020. Bij de prognoses voor 1994 is dit verlies 0,022. Aangezien echter het gemiddeld verlies van de referentieprognose is afgenomen van 0,0017 naar 0,0010 , is de score toegenomen van 1,18 naar 2,26. Kennelijk heeft de introductie van het model zoals beschreven in paragraaf 4.2 vooral winst opgeleverd in het voorspellen van de gemiddelde vervangingsvraag en daarmee van de referentieprognose en is het model minder succesvol geweest met betrekking tot het voorspellen van de opleidingsspecifieke component. Dit lijkt plausibel daar aan de ene kant de nieuwe methodiek de werkelijke vervangingsvraag in kaart brengt en niet gebaseerd is op de aanname dat alleen personen boven de 55 jaar de arbeidsmarkt zullen verlaten, maar aan de andere kant de nieuwe methode ook veel meetproblemen heeft geïntroduceerd. Hierdoor is de gemiddelde prognose verbeterd, maar is de prognose van de opleidingspecifieke component verslechterd.

\section{Een verklaring van voorspelfouten}

Tabel 4.10 geeft een beeld van de verklaringskracht van enkele mogelijke oorzaken van de voorspelfout van de vervangingsvraagprognoses per opleidingstype. Net als bij de overige onderdelen van de prognoses is de schaalparameter kleiner dan één. Dit betekent dat grotere opleidingstypen relatief beter voorspeld zijn dan kleinere opleidingen. De schaalparameter is overigens iets hoger dan bij de prognoses voor 1992. De andere variabelen die in de vergelijking opgenomen zijn blijken geen significante invloed op de voorspelfout te hebben. Dit geldt zowel voor de twee spreidingsindicatoren als voor het percentage werkzame vrouwen met de betreffende opleidingsachtergrond. Ook in het vorige evaluatierapport werd geen samenhang tussen de beide spreidingsindicatoren en de vervangingsvraag per opleidingstype gevonden.

De onderschattingscoëfficiënt toont aan dat er bij de vervangingsvraagprognoses per opleidingstype sprake is van een significante overschatting van afwijkingen van de referentieprognose. Deze bevinding sluit aan bij reeds eerder geconstateerde goede voorspelkwaliteit van de referentieprognose. Kennelijk zit er veel ruis in de 
opleidingsspecifieke prognoses, veroorzaakt door steekproeffouten in de data. Bovendien zou het, feit dat de gebruikte data relatief oud waren hierbij een rol kunnen hebben gespeeld. De referentieprognose is gebaseerd op een gemiddelde van alle afzonderlijke prognoses op en zal van deze meetfouten minder last hebben.

Tabel 4.10

Een verklaring van voorspelfouten in de vervangingsvraagprognoses per opleidingstype

\begin{tabular}{lrc}
\hline Variabele & Parameter & T-waarde \\
\hline Constante & 1,20 & 0,70 \\
Schaal & 0,64 & $5,16^{\star *}$ \\
Spreidingsindicator beroepen & $-0,50$ & $-0,15$ \\
Spreidingsindicator sectoren & 0,21 & 0,12 \\
Percentage vrouwen & 0,31 & $-0,40$ \\
Onderschattingscoëfficiënt & $-0,86$ & $-6,95^{\star *}$ \\
\hline
\end{tabular}

* significant bij betrouwbaarheid van $90 \%$

** signifcant bij betrouwbaarheid van $95 \%$

\section{Kwalitatieve typeringen}

Evenals bij de andere componenten van de prognose is bij de vervangingsvraag per opleidingstype een kwalitatieve typering gemaakt. De indeling van de kwalitatieve typeringen is als volgt:

\begin{tabular}{|c|c|c|c|c|c|}
\hline & & WVO & $\leq$ & $4 \%$ & erg laag \\
\hline $4 \%$ & $<$ & WVO & $\leq$ & $7 \%$ & laag \\
\hline $7 \%$ & $<$ & WVO & $s$ & $12 \%$ & gemiddeld \\
\hline $12 \%$ & $<$ & WVO & $\leq$ & $15 \%$ & hoog \\
\hline $15 \%$ & $<$ & VVO & & & erg hoog \\
\hline
\end{tabular}

waarbij WV staat voor vervangingsvraag per opleidingstype (Dekker e.a. 1992).

In tabel 4.11 geeft een overzicht van de voorspelde kwalitatieve typeringen en de realisaties. De tabel laat zien dat in 15 van de 47 gevallen (32\%) de prognose een exacte juiste typering heeft gekregen. Daarnaast wijkt bij 13 opleidingstypen (28\%) de voorspelde typering slechts één categorie af van de realisatie. Dit betekent dat er voor $60 \%$ van het totaal aantal opleidingstypen sprake is geweest van een juiste of redelijk juiste typering. Dit is een verbetering ten opzichte van de prognose voor 1992 waarvan $26 \%$ van de typeringen exact goed en $21 \%$ bijna goed waren. Het aantal juiste of bijna juiste typeringen is echter beduidend lager dan bij de vervangingsvraag per beroepsklasse $(75 \%)$. 
In totaal tien opleidingstypen hebben een typering gekregen die de verkeerde richting aangeeft. Dit is $21 \%$ van het totaal. Voor slecht één opleiding, MBO sociaalcultureel, is de prognose als 'hoog' getypeerd, terwijl de realisatie als 'laag' getypeerd kan worden. In negen gevallen was de prognose 'laag' of 'erg laag', terwijl de gerealiseerde vervangingsvraag 'hoog' of 'erg hoog' is geweest. De tabel toont aan dat er vijf extreme typeerfouten aangewezen kunnen worden. Voor de VBOrichting haven en vervoer geldt dat de prognose erg laag is geweest, terwijl de realisatie hoog is geweest. Voor vier opleidingstypen blijkt de vervangingsvraag erg hoog te zijn geweest, terwijl de prognose als 'laag' is getypeerd. Het gaar hier om de opleidingen: VBO beveiliging en bewaking, MBO technisch laboratorium, HBO technische bedrijfskunde en WO technisch.

Tabel 4.11

Typeringen van de vervangingsvraag per opleidingstype

\begin{tabular}{lcccccc}
\hline & \multicolumn{5}{c}{ Prognose } \\
Realisatie & erg laag & laag & gemiddeld & hoog & erg hoog & totaal \\
\hline Erg laag & 0 & 0 & 0 & 0 & 0 & 0 \\
Laag & 0 & 1 & 2 & 1 & 0 & 4 \\
Gemiddeld & 2 & 4 & 10 & 3 & 1 & 20 \\
Hoog & 1 & 4 & 3 & 1 & 0 & 9 \\
Erg hoog & 0 & 4 & 6 & 1 & 3 & 4 \\
Totaal & 3 & 13 & 21 & 6 & 4 & 47 \\
\hline
\end{tabular}

\section{Conclusies}

Uit de empirische evaluatie van de vervangingsvraagprognoses per opleidingstype kunnen de volgende conclusies getrokken worden. Op de eerste plaats zijn de prognoses, gemiddeld genomen, te laag geweest. Verder blijkt de referentieprognose - de gemiddelde vervangingsvraag - een opvallende goede voorspelkwaliteit op te leveren vergeleken met de daadwerkelijke prognoses. Hiervoor kunnen verschillende oorzaken aangegeven worden. Op de eerste plaats heeft de destijds gehanteerde methodiek geleid tot een aantal ten onrechte extreme prognoses. Op de tweede plaats is er gebruik gemaakt van relatief oude data, omdat door de overgang van de AKT naar de EBB geen betrouwbare verloopratio's over een latere waarnemingsperiode beschikbaar waren. Ten derde zou het feit dat het moeilijk is gebleken opleidingsspecifieke componenten in de vervangingsvraag te voorspellen, veroorzaakt kunnen zijn door meetfouten in de data.

Verwacht mag worden dat de thans gehanteerde prognosemethodiek boven- 
genoemde problemen voor een aanzienlijk deel kan ondervangen. Op de eerste plaats wordt thans gebruik gemaakt van een random-coëfficiëntenmodel, hetgeen betekent dat er beter omgegaan kan worden met extreme prognoses. Op de tweede plaats is de datareeks langer geworden en bovendien wordt er gebruik gemaakt van recentere data. Ten derde worden, meer dan destijds, de door het model gegenereerde prognoses achteraf op hun plausibilteit getoetst en zonodig bijgesteld. 



\section{Baanopeningen}

\subsection{Inleiding}

De mogelijkheden voor nieuwkomers om op de arbeidsmarkt werk te vinden binnen een bepaalde beroepsklasse worden bepaald door de baanopeningen. De baanopeningen worden berekend uit de prognoses voor de uitbreidings- en de vervangingsvraag. In dit hoofdstuk wordt achtereenvolgens aandacht geschonken aan de berekeningswijze van het totaal aantal baanopeningen en aan de resultaten van de empirische evaluatie van de prognoses.

\subsection{Prognosemethodiek}

Het begrip baanopeningen geeft aan hoeveel arbeidsplaatsen er beschikbaar komen voor mensen die niet reeds werkzaam zijn in de betreffende beroepsklasse of met de betreffende opleidingsachtergrond. Deze baanopeningen kunnen voortkomen uit een groei van de werkgelegenheid, maar ook doordat er een arbeidsplaats beschikbaar komt door het vertrek van een reeds werkende persoon. In het eerste geval is er sprake van uitbreidingsvraag; in het tweede geval van vervangingsvraag.

Er wordt bij de berekening van het aantal baanopeningen een onderscheid gemaakt tussen beroepsklassen waarvoor de verwachte uitbreidingsvraag positief is en beroepsklassen waarin een afname van de werkgelegenheid verwacht wordt en uitbreidingsvraag derhalve negatief is ${ }^{18}$. Voor beroepsklassen met een positieve uitbreidingsvraag is het aantal baanopeningen gelijk aan de som van uitbreidingsen vervangingsvraag. Wanneer de uitbreidingsvraag negatief is moet dit niet in mindering gebracht worden op het aantal baanopeningen, omdat dit dan voor de tweede keer zou gebeuren. Immers bij het bepalen van de vervangingsvraag is reeds verondersteld dat de arbeidsmarktuitstroom slechts tot vervangingsvraag leidt voorzover de vertrekkende arbeidskracht daadwerkelijk wordt vervangen. Het aantal baanopeningen is in dat geval dus gelijk aan de vervangingsvraag.

Bij de eerdere prognoses voor 1992 werd dit onderscheid tussen groeiende en krimpende beroepen nog niet gemaakt. De oorzaak voor deze verandering is gelegen in de aanpassing in de vervangingsvraagmethodiek. Zoals reeds werd beschreven in paragraaf 4.2, werd in 1992 feitelijk een prognose van de arbeidsmarktuitstroom opgesteld. Als wordt uitgegaan van de uitstroom dan is het aantal banen dat beschikbaar is voor nieuwkomers gelijk is aan de som van uitstroom en uitbreidingsvraag:

18. Opgemerkt dient te worden dat de vervangingsvraag per definitie positief is. 
Bij de thans geëvalueerde prognoses voor 1994 is voor het eerst daadwerkelijk de vervangingsvraag voorspeld. Het hierboven beschreven verband tussen vervangingsvraag en uitstroom is in formulevorm als volgt:

vervangingsvraag $=$ uitstroom + MIN $\{$ uitbreidingsvraag, 0$\}$

Dit impliceert dat:

baanopeningen $=$ vervangingsvraag $+\operatorname{MAX}\{$ uitbreidingsvraag, 0$\}$

Substitutie van de definitie van vervangingsvraag in de berekeningswijze voor de baanopeningen (11) laat zien dat beide berekeningswijzen hetzelfde resultaat opleveren.

\subsection{Empirische analyse prognoses baanopeningen}

Het feit dat de baanopeningen worden berekend uit de prognoses voor de uitbreidings- en de vervangingsvraag impliceert dat de voorspelkwaliteit van de baanopeningen bepaald wordt door de kwaliteit van de prognoses betreffende de twee afzonderlijke componenten. Het enige punt dat hierbij speelt is dat de bij de uitbreidings- en vervangingsvraagprognoses gemaakte voorspelfouten elkaar in principe zowel kunnen versterken als compenseren. Vanuit het oogpunt van het verbeteren van de prognosemethodiek behoeven de prognoses van de baanopeningen derhalve niet uitvoerig geëvalueerd te worden. De evaluatie blijft daarom beperkt tot een beschrijving van de voorspelfout per beroepsklasse, een analyse van de het gemiddeld verlies van de relatieve prognoses en een beschouwing van de trefzekerheid van de kwalitatieve typeringen.

Tabel 5.1 geeft de voorspelkwaliteit per beroepsklasse weer. De tabel toont de voorspelfout en het verlies. De grootste uitschieters in negatieve zin zijn de technisch tekenaars, natuurkundigen, technologen en statistici, monteurs energievoorziening, leidinggevend administratief personeel en journalisten en presentatoren. Met uitzondering van de monteurs energievoorziening is er sprake van een negatieve voorspelfout. Het voorspelde aantal baanopeningen bij deze beroepsklassen was beduidend hoger dan het gerealiseerde aantal. De oorzaak van deze voorspelfout is in alle vier gevallen gelegen in de te hoge uitbreidingsvraagprognose. Goede voorspellingen van het aantal baanopeningen zijn er daaren-tegen gemaakt voor de machinebank-, plaatwerkers en smeden, de monteurs en controleurs elektrotechnische installaties, de wegenbouwvakkrachten en buizen-leggers, de vliegers, verkeersleiders en expediteurs en het politie- en beveiligingspersoneel. 


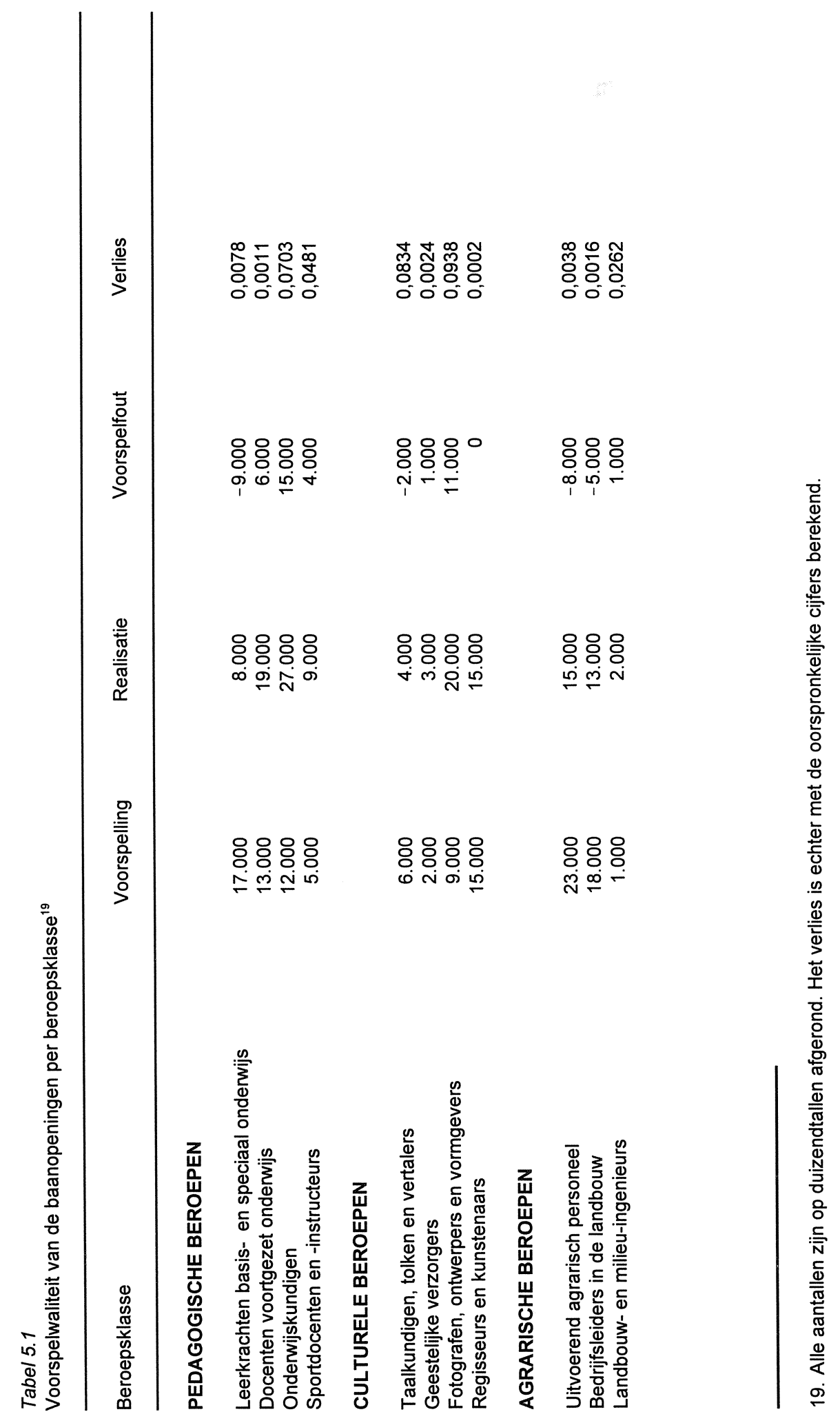




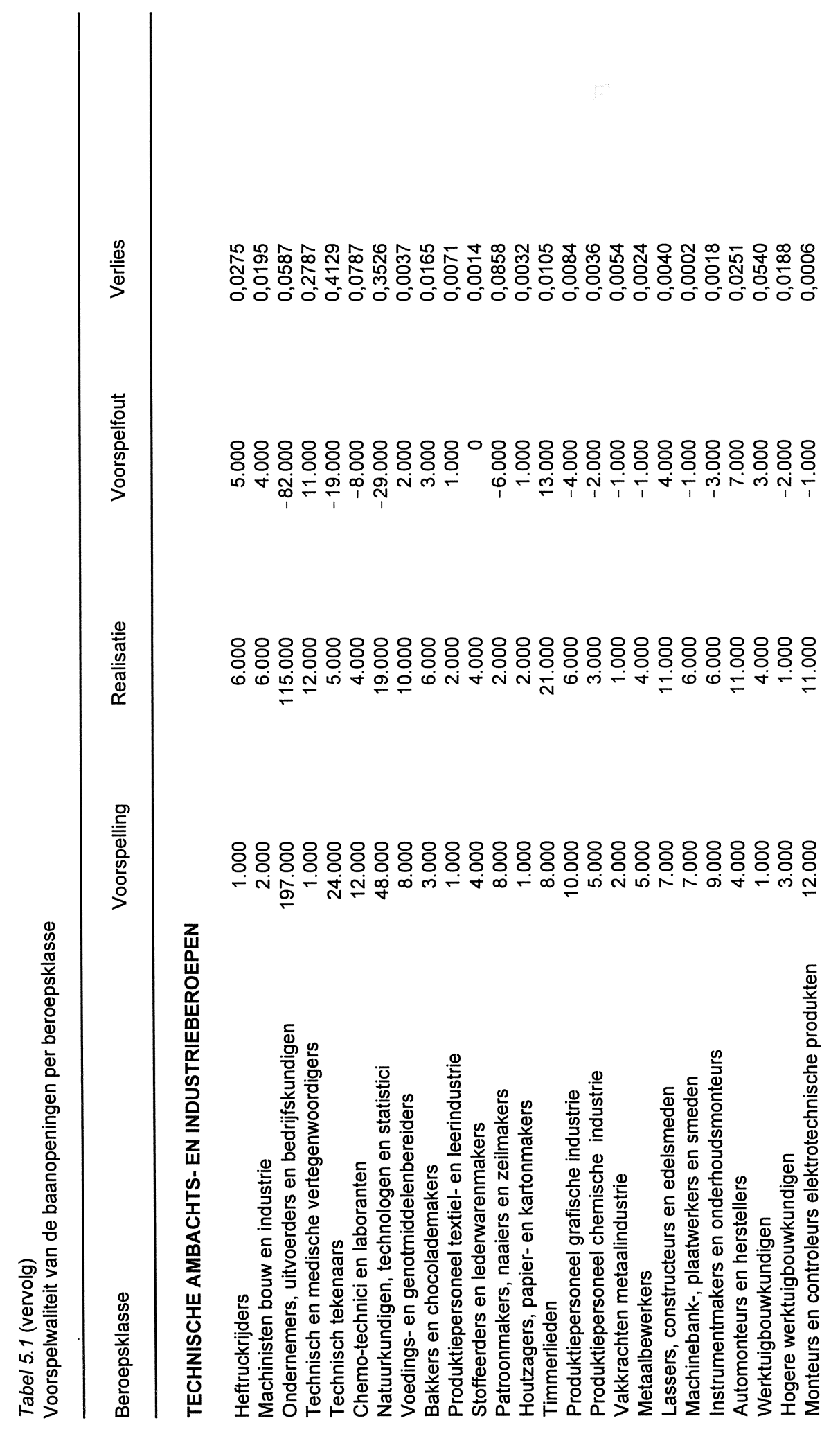




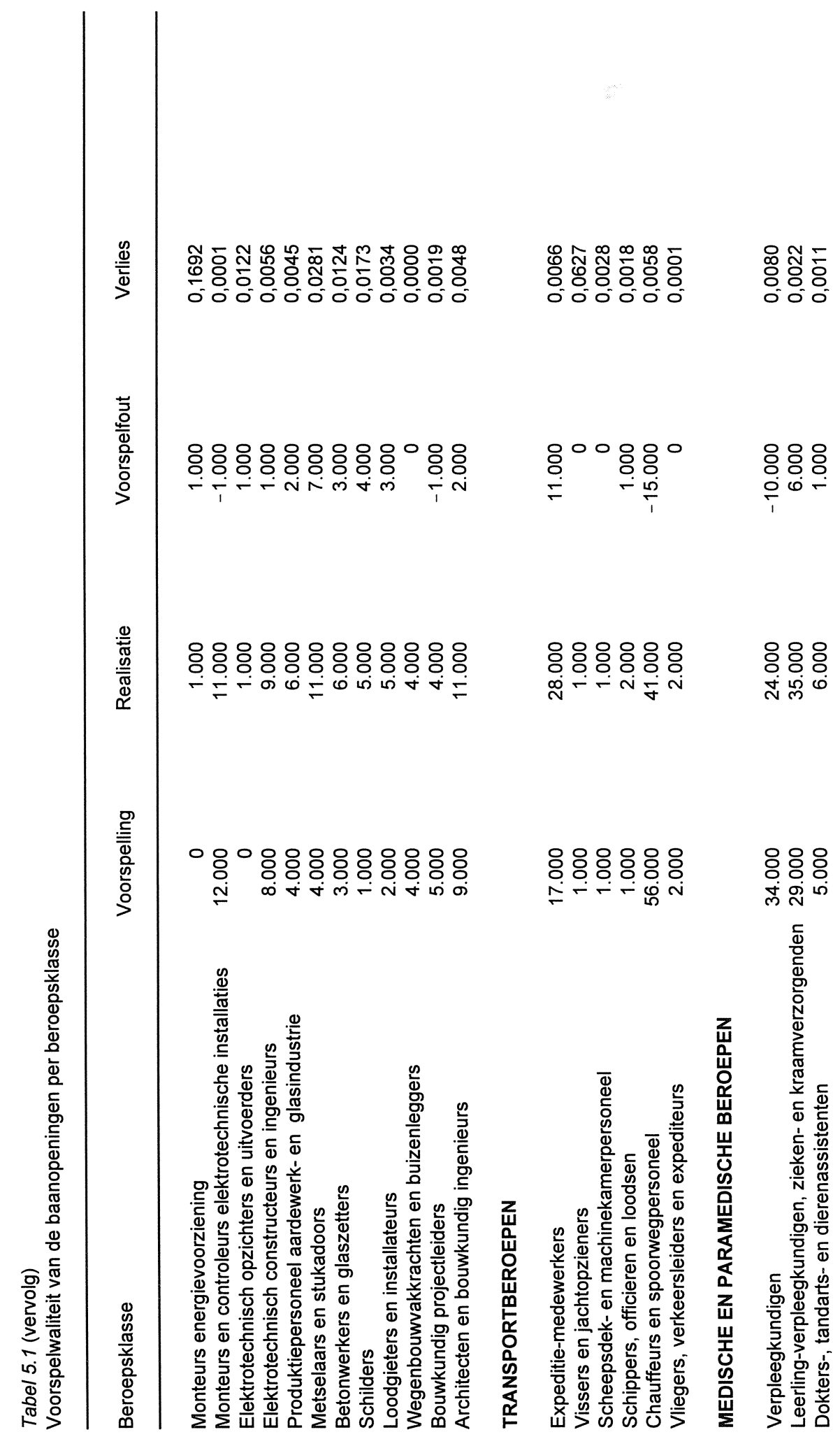




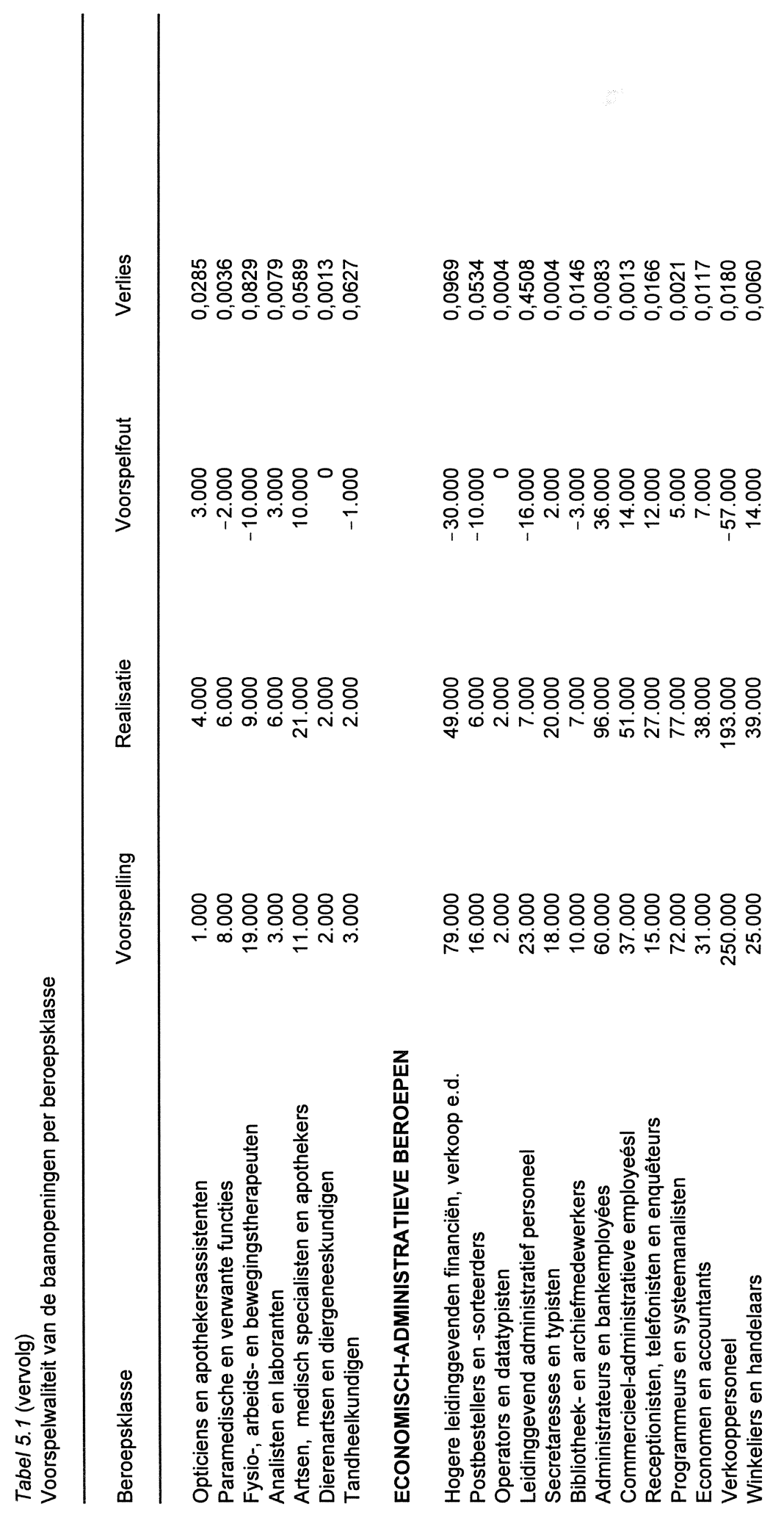




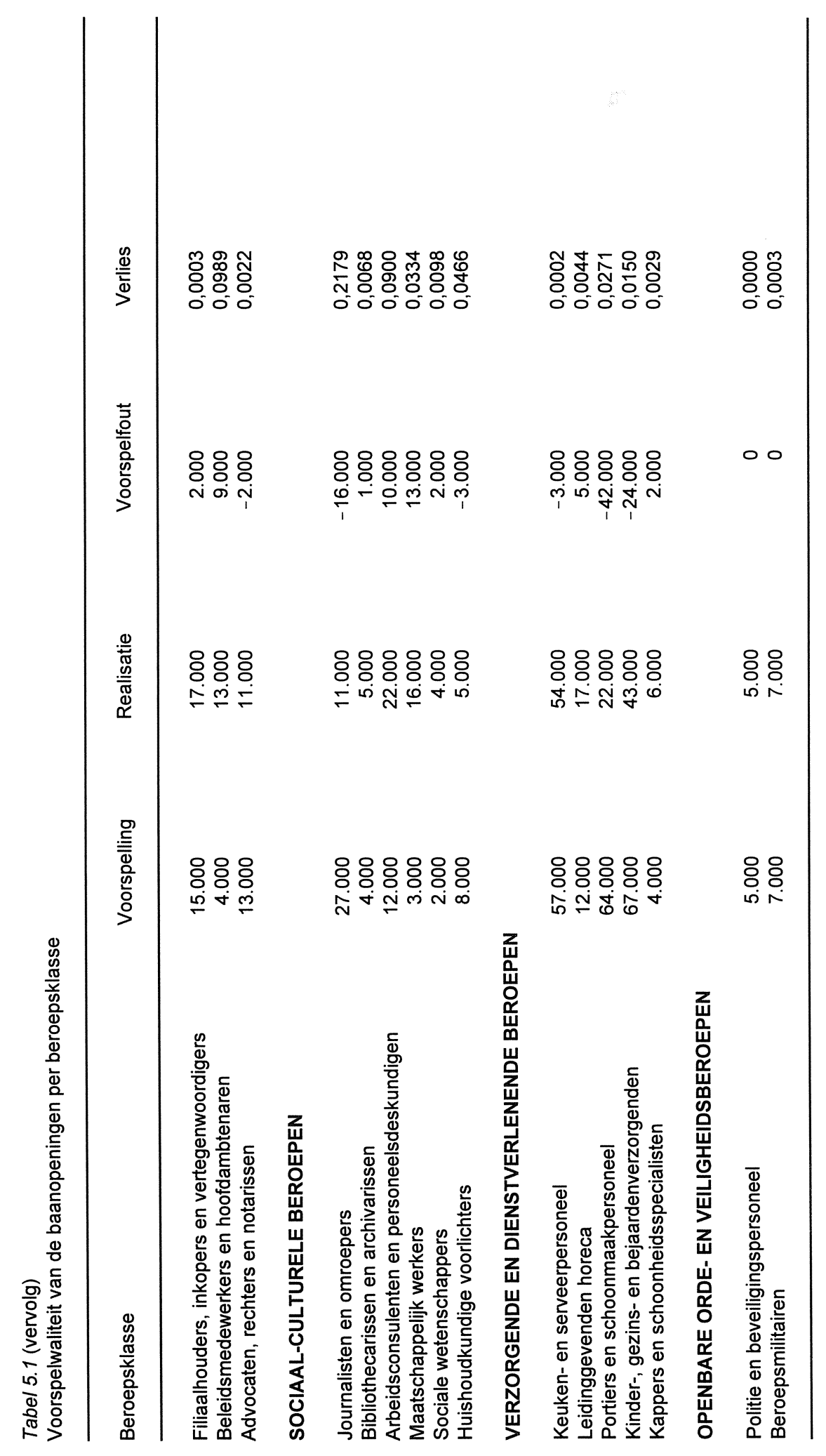


Het verlies voor deze beroepsklassen is erg klein.

De voorspelkwaliteit van de prognoses van het aantal baanopeningen wordt vanzelfsprekend met name bepaald door de kwaliteit van de afzonderlijke componenten: de uitbreidingsvraag- en de vervangingsvraag. De samenhang tussen de voorspelfouten van beide componenten speelt echter ook een rol. Wanneer er een positieve samenhang bestaat, versterken beide fouten elkaar. In het geval van een negatieve correlatie daarentegen zal het gemiddeld verlies van de prognoses van de baanopeningen lager zijn dan de som van de componenten. In tabel 5.2 wordt de opbouw van het gemiddeld verlies van prognoses van de baanopeningen nader geanalyseerd.

\section{Tabel 5.2}

Opbouw van het gemiddeld verlies van de prognose van de baanopeningen per beroepsklasse

\begin{tabular}{|c|c|c|c|}
\hline Onderdeel & $\begin{array}{l}\text { Gem. verlies } \\
\text { prognose }\end{array}$ & $\begin{array}{l}\text { Gem. verlies } \\
\text { referentieprognose }\end{array}$ & Score \\
\hline Uitbreidingsvraag & 0,0344 & 0,0600 & 0,57 \\
\hline Positieve uitbreidingsvraag & 0,0234 & 0,0404 & 0,58 \\
\hline Vervangingsvraag & 0,0022 & 0,0016 & 1,39 \\
\hline $\begin{array}{l}\text { Covariantie uitbreidings- en } \\
\text { vervangingsvraag }\end{array}$ & $-0,0017$ & 0,0023 & \\
\hline Baanopeningen & 0,0221 & 0,0466 & 0,45 \\
\hline
\end{tabular}

Tabel 5.2 laat zien hoe het gemiddeld verlies van de baanopeningen is opgebouwd. Ten eerste is alleen gekeken naar de uitbreidingsvraag voor zover deze relevant is voor de bepaling van het aantal baanopeningen. Wanneer de prognose negatief is, is de uitbreidingsvraag op 0 gesteld. Het gemiddeld verlies van de positieve uitbreidingsvraag blijkt kleiner te zijn dan het gemiddeld verlies van de totale uitbreidingsvraag zoals in paragraaf 3.3 werd gepresenteerd. Het verlies van de positieve uitbreidingsvraag is 0,0234 , terwijl het verlies van de oorspronkelijke uitbreidingsvraagprognose 0,0344 bedroeg. Dit resultaat is niet verrassend, aangezien door het negeren van de negatieve uitbreidingsvraag een deel van de variantie, en daarmee van de gemiddelde absolute voorspelfout, weggenomen wordt. Het gemiddeld verlies voor de vervangingsvraag is 0,0022 . Dit impliceert dat wanneer beide fouten onafhankelijk waren geweest, het totale gemiddeld verlies 0,0256 zou hebben bedragen. Er blijkt echter een negatieve covariantie tussen de voorspelfout van beide vraagcomponenten te bestaan. Deze covariantie bedraagt 0,0017 . Als gevolg van de negatieve covariantie bedraagt het verlies van de 
baanopeningen slechts $0,0211^{20}$. Overigens zou op theoretische gronden eerder geen of een positief verband tussen de positieve uitbreidingsvraag en de vervangingsvraag verwacht worden. Er kan echter geen verklaring voor deze negatieve samenhang gegeven worden.

Wanneer deze resultaten vergeleken worden met de resultaten van de vorige evaluatie, blijkt ook met betrekking tot de baanopeningen het gemiddeld verlies beduidend lager te zijn. Het gemiddeld verlies is gedaald van 0,0623 naar 0,0211 . Ook bij de vorige evaluatie werd een negatieve covariantie tussen beide vraagcomponenten gevonden. De covariantie is nu echter beduidend lager. Bij de vorige evaluatie was de covariantie $-0,0142$, terwijl thans een covariantie van $-0,0017$ wordt gevonden. Voor dit aanmerkelijke verschil kunnen twee oorzaken aangewezen worden. Op de eerste plaats impliceert de methodiekverandering van de vervangingsvraagprognoses dat op theoretische gronden geen negatieve covariantie meer wordt verwacht. Op de tweede plaats wordt, door het op 0 stellen van de uitbreidingsvraagprognose wanneer deze negatief is, een deel van de variantie en daarmee van de covariantie weggenomen. Dit leidt tot een afname van de correlatiecoëfficiënt van $-0,39$ tot $-0,24$. De covariantie wordt kennelijk met name veroorzaakt door de afnemende variantie van de positieve uitbreidingsvraag en vervangingsvraag. Bij de referentieprognose is de correlatie juist positief. Dit bevestigt het beeld dat bij een onverwacht krimpende werkgelegenheid de vervangingsvraag toch enigszins daalt. De referentieprognose houdt hier per definitie geen rekening mee. Bij de referentieprognose versterken de voorspelfouten in de uitbreidingsvraag en de vervangingsvraag elkaar dus. Dit leidt ertoe dat de score voor de prognose van de baanopeningen per beroepsklasse met 0,45 lager is dan van beide afzonderlijke componenten.

\section{Kwalitatieve typeringen}

Voor de kwalitatieve typering van de prognoseresultaten is de volgende indeling gehanteerd:

$\begin{aligned} & & \text { TBK } & \leq & 3 \% & \text { erg laag } \\ 3 \% & < & \text { TBK } & \leq & 13 \% & \text { laag } \\ 13 \% & < & \text { TBK } & \leq & 27 \% & \text { gemiddeld } \\ 27 \% & < & \text { TBK } & \leq & 37 \% & \text { hoog } \\ 37 \% & < & \text { TBK } & & & \text { erg hoog }\end{aligned}$

waarbij TBK staat voor het totaal aantal baanopeningen in een beroepsklasse

20. Aangezien geldt dat $\operatorname{Var}(a+b)=\operatorname{Var}(a)+\operatorname{Var}(b)+2 \operatorname{Cov}(a, b)$. 
(Dekker e.a. 1992).

Tabel 5.3 geeft een overzicht van de kwalitatieve typeringen van de prognoses en de realisaties. Hierbij is opnieuw gebruik gemaakt van de relatieve prognoses. De tabel laat zien dat 41 van de 93 beroepsklassen een geheel juiste typering heeft gekregen. In maar liefst 78 gevallen is er sprake van een typering die ten hoogste één typering naast de prognose ligt. Dit betekent dat $44 \%$ van de beroepsklassen een juiste en in totaal $84 \%$ een juiste of bijna juiste typering heeft gekregen. Het aantal beroepsklassen waarin sprake is van een typering die tegengesteld is aan de prognose is derhalve erg klein. Er zijn twee beroepsklassen waarvoor de prognose van het aantal baanopeningen de typering 'hoog' heeft gekregen, terwijl het gerealiseerde aantal baanopeningen 'laag' is geweest. Het gaat hier om de beroepsklassen: patroonmakers, naaiers en zeilmakers en postbestellers en -sorteerders. Daarnaast blijkt voor de technisch en medisch vertegenwoodigers het gerealiseerde aantal baanopeningen 'erg hoog' te zijn, terwijl de prognose 'laag' is.

Tabel 5.3

Typeringen van de baanopeningen per beroepsklasse (relatief)

\begin{tabular}{lcccccc}
\hline & \multicolumn{5}{c}{ Prognose } \\
Realisatie & erg laag & laag & gemiddeld & hoog & erg hoog & totaal \\
\hline Erg laag & 0 & 0 & 0 & 0 & 0 & 0 \\
Laag & 1 & 10 & 9 & 2 & 0 & 22 \\
Gemiddeld & 1 & 13 & 9 & 4 & 3 & 30 \\
Hoog & 0 & 4 & 7 & 0 & 2 & 13 \\
Erg hoog & 0 & 1 & 3 & 2 & 22 & 28 \\
Totaal & 2 & 28 & 28 & 8 & 27 & 93 \\
\hline
\end{tabular}

De trefzekerheid van de kwalitatieve typeringen is relatief hoog vergeleken met de typeringen uitbreidingsvraag. Dit wordt veroorzaakt door een tweetal factoren. Ten eerste is de voorspelfout van de prognoses van het aantal baanopeningen aanmerkelijk lager dan bij de prognoses voor 1992. Ten tweede spelen hier, in vergelijking met de resultaten bij de uitbreidingsvraag die een gemiddeld verlies in dezelfde orde van grootte kent, de kleinere voorspelfout van de prognoses, de brede intervallen die gehanteerd zijn en de onevenwichtige verdeling van de beroepsklassen over de verschillende typeringen. Met name valt op dat het interval waarin het aantal baanopeningen als 'erg laag' getypeerd wordt, bij de prognoses slechts twee beroepsklassen bevat. De gehanteerde intervallen zijn echter slechts marginaal breder dan bij de prognoses tot 1992. 
Aangezien de trefzekerheid van zowel de uitbreidings- als de vervangingsvraag naar beroepsklasse beduidend hoger bleek te zijn dan bij de prognoses voor 1992, is het niet verrassend dat ook de voorspelkwaliteit van de kwalitatieve typeringen van het totaal aantal baanopeningen is verbeterd. Het aandeel van de exact juiste typeringen is gestegen van 33 naar $44 \%$, terwijl het aantal geheel of bijna juiste typeringen flink is gestegen van 63 naar $84 \%$. Ten slotte was er bij de vorige evaluatie in $30 \%$ van de gevallen sprake van een prognose aan de 'verkeerde kant' van het gemiddelde. Bij de prognoses die hier worden geëvalueerd komt dit nog slechts bij $4 \%$ van het totaal aantal beroepsklassen voor.

\section{Conclusies}

Uit de empirische evaluatie van de prognoses van het totaal aantal baanopeningen per beroepsklasse kunnen de volgende conclusies getrokken worden. Op de eerste plaats is de gemiddelde voorspelfout relatief laag vergeleken met de uitbreidingsvraagprognoses en vervangingsvraagprognoses. De oorzaak hiervan is gelegen in de negatieve correlatie tussen uitbreidings- en vervangings-vraagprognoses. Op de tweede plaats is de trefzekerheid van de kwalitatieve typeringen hoog. 



\section{De instroom van schoolverlaters}

\subsection{Inleiding}

In het Informatiesysteem Onderwijs-Arbeidsmarkt is de arbeidsmarktinstroom van schoolverlaters de belangrijkste prognosecomponent van de aanbodzijde van de arbeidsmarkt. Deze arbeidsmarktinstroom vormt te zamen met de aan het begin van de prognoseperiode op de arbeidsmarkt aanwezige kortdurig werklozen het arbeidsaanbod. Aangezien het hierbij niet om een prognose gaat is aan deze werkloosheidscomponent geen afzonderlijk hoofdstuk gewijd.

De prognoses van de arbeidsmarktinstroom van schoolverlaters zijn gebaseerd op de onderwijsprognoses van het Ministerie van Onderwijs en Wetenschappen. Deze prognoses zijn omgerekend naar de verwachte aantallen gediplomeerde schoolverlaters per opleidingstype en aangevuld met behulp van andere informatiebronnen met betrekking tot het niet-reguliere onderwijs. Omdat in het verleden deze aanpassingen alleen uitgevoerd werden voor de prognoseperiode, waren er bij de vorige evaluatie geen gegevens beschikbaar om de prognoses tot 1992 te evalueren. Destijds is daarom volstaan met een empirische evaluatie van de prognoses van het ministerie.

Bij de meest recente prognoses van het informatiesysteem onderwijs-arbeidsmarkt voor de periode 1995-2000 (ROA, 1995 a,b) zijn echter ook de instroomcijfers voor de periode 1990-1995 vastgesteld. Omdat de hiervoor gebruikte gegevens pas vanaf 1990 beschikbaar zijn konden voor 1989 geen instroomcijfers worden vastgesteld. Daarom is bij het vaststellen van de feitelijke arbeidsmarktinstroom van schoolverlaters in de periode 1989-1994 de instroom in het jaar 1990 tweemaal opgenomen.

De arbeidsmarktinstroom in 1990 is tevens als referentieprognose gehanteerd. Naast het feit dat het hier een jaar betreft dat na het basisjaar van de prognoses ligt, heeft dit als bezwaar dat deze gereconstrueerde cijfers informatie bevatten die niet bekend was toen de prognoses werden opgesteld. Dit betreft met name informatie over het niet-regulier onderwijs. Verder sluit deze referentieprognose volledig aan bij de cijfers die voor de evaluatie gebruikt worden, terwijl er tussen de prognose en deze evaluatiecijfers belangrijke methodeverschillen voorkomen. De scorecijfers met betrekking tot deze instroomprognoses dienen in dit opzicht dus gerelativeerd te worden.

\subsection{Methodiek van de instroomprognoses}

De arbeidsmarktinstroomprognoses per ROA-opleidingstype zijn gebaseerd op De 
SKILL-onderwijsprognoses van het Ministerie van Onderwijs en Wetenschappen (zie Berendsen e.a. 1992). Dat zijn prognoses van de leerlingaantallen in het regulier voltijdsonderwijs, de aantallen behaalde diploma's en de aantallen schoolverlaters. Later zijn deze prognoses voortgezet als de Referentie-Raming.

Op basis van de prognoses van aantallen gediplomeerden per opleiding wordt de uitstroom van gediplomeerden per opleiding bepaald. Daarbij is gebruik gemaakt van de onderwijsmatrix van het CBS. De onderwijsmatrix heeft betrekking op het voltijdsonderwijs en geeft informatie over de in-, door- en uitstroom in twee opeenvolgende schooljaren. Op basis van deze matrix kan de doorstroom naar vervolgopleidingen in het voltijds regulier onderwijs worden bepaald en kan dus ook nagegaan worden hoeveel gediplomeerden het reguliere onderwijssysteem verlaten. Bij de prognose wordt verondersteld dat deze uitstroomfracties constant in de tijd blijven. Deze aanname blijkt echter niet helemaal juist. Om die reden hebben Borghans en Matheeuwsen (1996) een model ontwikkeld dat de ontwikkeling van dergelijke fracties in de tijd voorspeld. Uit dit onderzoek blijkt dat een aanzienlijk deel van de veranderingen in de uitstroomfracties uit eenmalige schokken bestaat. Daarnaast valt een trend in de ontwikkeling waar te nemen.

Aan de prognose van de uitstroom van gediplomeerde schoolverlaters wordt de uitstroom van ongediplomeerde schoolverlaters toegevoegd. Schoolverlaters die hun laatst gevolgde voltijdsopleiding zonder diploma hebben afgesloten, worden daarbij toegerekend aan hun hoogst behaalde vooropleiding. In de AKT en EBB, die de belangrijkste databron vormen voor de ontwikkelingen in de opleidingenstructuur van de vraagzijde van de arbeidsmarkt, wordt immers de hoogst behaalde onderwijskwalificatie van een individu geregistreerd. De hoogst behaalde vooropleiding wordt eveneens bepaald met behulp van de CBS-onderwijsmatrix, op basis van de veronderstelling dat de ongediplomeerden proportioneel verdeeld zijn over de herkomstbestemmingen van alle leerlingen in het betreffende onderwijssoort.

Overigens wordt de informatie in zowel de SKILL-prognoses als de onderwijmatrix op een hoger aggregatieniveau gepresenteerd dan de opleidingstypen die in het informatiesysteem worden onderscheiden. In de SKILL-prognoses werden 39 opleidingsrichtingen onderscheiden. Deze zijn gekoppeld aan de 27 schoolsoorten die het CBS in de onderwijsmatrix onderscheidt. De prognoses van de uitstroom per schoolsoort zijn uiteindelijk verdeeld over de 49 opleidingstypen. Dat is gebeurd met behulp van verschillende aanvullende databronnen, namelijk de Integrale leerlingtelling (ILT) 1990/1991, de statistieken van het lager en middelbaar beroepsonderwijs voor 1989/1990 van het CBS, de werktabellen die het CBS heeft gebruikt bij het opstellen van de onderwijsmatrix en de Wetenschappelijke Onderwijs Raming Studentenaantallen (WORSA) uit 1990 van de Taakgroep Studentenramingen. Overigens werd ook hierbij verondersteld dat de betreffende verdelingen 
over de opleidingstypen constant zijn in de tijd. Bij de meest recente prognoses voor de periode $1995-2000$ is deze aanname aangepast.

Met de prognoses van de uitstroom uit het reguliere onderwijs ligt de totale toekomstige instroom van schoolverlaters op de arbeidsmarkt vast. Degenen die uitstromen uit het regulier voltijdsonderwijs kunnen echter doorstromen naar een vorm van niet-regulier voltijdsonderwijs of naar een deeltijdopleiding. Als iemand een dergelijke opleiding met een diploma afsluit en de opleiding ligt op een hoger niveau, dan vermindert de arbeidsmarktinstroom vanuit het opleidingstype waartoe de vooropleiding behoort, terwijl de arbeidsmarktinstroom van het opleidingstype waartoe de vervolgopleiding wordt gerekend toeneemt ${ }^{21}$.

In de tweede stap van de instroomprognoses heeft daarom een herverdeling plaats gevonden van de uitstroom uit het voltijds regulier onderwijs, op basis van prognoses van de uitstroom uit het deeltijd-onderwijs en een aantal niet-reguliere opleidingen en het beroepsgerichte volwassenonderwijs.

De prognoses van de gediplomeerden-uitstroom uit het deeltijd onderwijs zijn opgebouwd uit prognoses voor het deeltijd-KMBO en het leerlingwezen, prognoses voor de eerste fase van het deeltijd-HBO, prognoses voor de tweede fase van het $\mathrm{HBO}$ en prognoses voor de tweede fase lerarenopleiding in het WO. Hiervoor is naast de SKILL-onderwijsprognoses en de CBS-onderwijsmatrix ook nog gebruik gemaakt van de Opgave van het Leerlingwezen (OVL) 1988/1989, de Raming Hoger Beroepsonderwijs Studentenaantallen (RHOBOS) 1990 van de taakgroep studentenramingen, de Statistiek voor het hoger beroepsonderwijs van het $C B S$, de HBO-werktabellen die het CBS heeft gebruikt bij het opstellen van de onderwijsmatrix, cijfers van de Vereniging van Samenwerkende Nederlandse Universiteiten (VSNU) over de lerarenopleiding in de tweede fase van het WO en WORSA 1990.

Niet-reguliere opleidingen waarvoor uitstroomprognoses zijn gemaakt zijn opleidingen in openbare orde en veiligheid, in-service opleidingen, de Rijksacademies van Beeldende Kunsten, de Universiteit voor bedrijfskunde (Nijenrode) en de opleiding tot registeraccountant van het NIVRA. Hiervoor is gebruik gemaakt van uiteenlopende databronnen.

21. Er wordt verondersteld dat het aantal personen dat doorstroomt naar niet-regulier of deeltijdonderwijs en deze opleiding niet binnen de prognoseperiode afrondt bij benadering wegvalt tegen het aantal personen dat voor het begin van de prognoseperiode in het nietregulier of deeltijdonderwijs instroomden en gedurende deze periode hun opleiding afrondden. 
De prognoses van de gediplomeerde uitstroom uit het beroepsgerichte volwassenenonderwijs zijn opgebouwd uit prognoses voor het deeltijd-AVO, -LBO en $-\mathrm{MBO}$, de Open Universiteit (OU), het erkend schriftelijk onderwijs (ESO) en het buitenschools mondeling onderwijs (BMO), bedrijfsopleidingen en het overige beroepsgerichte volwassenenonderwijs.

De methodiek van de instroomprognoses is bij latere prognoses in grote lijnen gelijk gebleven. Wel is bij latere prognoses bij het bepalen van de hoogst voltooide vooropleiding van schoolverlaters zonder diploma rekening gehouden met schoolverlaters die ook bij de eerder door hen gevolgde opleiding zonder diploma zijn uitgestroomd. Daarnaast is de eerder genoemde modelveronderstelling van constante verdeelcoëfficiënten losgelaten.

Ook hebben er bij latere prognoses enkele veranderingen met betrekking tot de gebruikte databronnen plaatsgevonden. De belangrijkste verandering ten aanzien van de gebruikte databronnen in de eerste stap van de instroomprognoses betreft de overstap van de SKILL-prognoses naar de Referentie-Raming 1993. De Referentieraming geeft naast prognoses voor het aantal leerlingen en het aantal gediplomeerden ook prognoses voor het aantal schoolverlaters naar schoolsoort. De uitstroom uit het onderwijs volgt dus direct uit de Referentie-Raming en hoeft dus niet meer bepaald te worden op basis van de CBS-onderwijsmatrix. Verder wordt nu gebruik gemaakt van de WO-verdeelraming van het Ministerie van Onderwijs, Cultuur en Wetenschappen in plaats van de WORSA-ramingen. De belangrijkste veranderingen op dat punt in de tweede stap zijn het gebruik van HBOverdeelraming in plaats van RHOBOS voor de prognose van het regulier deeltijd onderwijs en het gebruik van de Referentie-Raming voor de prognoses voor het KMBO en leerlingwezen in plaats van de OVL. Verder wordt de CBS-statistiek bedrijfsopleidingen in Nederland 1986 niet meer gebruikt. Enerzijds heeft deze aanpassing plaatsgevonden omdat interne bedrijfsopleidingen vaak geen invloed hebben op het kwalificatieniveau zoals dat door het CBS wordt gemeten en anderzijds omdat dergelijke opleidingen waarschijnlijk ook reeds in andere bronnen geregistreerd zijn. Ten slotte wordt bij het bepalen van de doorstroom naar het vervolgonderwijs gebruik gemaakt van gegevens uit de schoolverlatersenquêtes RUBS en HBO-Monitor.

De arbeidsmarktinstroom van met name het niet-reguliere onderwijs wordt voor een belangrijk deel dus vastgesteld afhankelijk van de beschikbare databronnen en op basis van een subjectief oordeel over het kwalificatieverhogend karakter van de opleiding. Omdat deze twee aspecten kunnen verschillen tussen de verschillende prognoses, wordt de empirische evaluatie, zoals reeds is opgemerkt, ernstig verstoord. Verder is het moeilijk om vast te stellen of alle relevante onderwijsstromen zijn opgenomen in het model. Om die reden is voor 1996 een onderzoek 
geprogrammeerd waarin de onderwijsstromen die in het informatiesysteem worden vastgesteld worden vergeleken met de stromen die in de EBB worden vastgesteld.

\subsection{Een empirische evaluatie van de instroomprognoses}

De arbeidsmarktinstroomprognoses zullen op twee niveaus empirisch worden geëvalueerd. Ten eerste wordt de belangrijkste bron voor de instroomprognoses, de SKILL-prognoses van het aantal gediplomeerden per opleiding in het voltijds regulier onderwijs geëvalueerd. Vervolgens worden de instroomprognoses van het ROA geëvalueerd. Op deze wijze wordt enig inzicht gekregen in het relatieve belang van voorspelfouten in de eerste en in de tweede stap van de instroomprognoses.

\section{Skill-prognoses}

De SKILL-prognoses van het aantal gediplomeerden per opleiding worden geëvalueerd op basis van de informatie over de historische periode in de ReferentieRaming (OCW, 1995). Het aantal gediplomeerden van het schooljaar 1988/1989 vermenigvuldigd met het aantal prognosejaren (5) is als referentieprognose genomen. Tabel 6.1 geeft een overzicht van de SKILL-prognoses en de realisatie daarvan $^{22}$. De tabel laat zien dat de relatief grootste fout is gemaakt bij het Hoger Sociaal-Agogisch Onderwijs. De prognose van het aantal gediplomeerden is bij deze opleiding meer dan twee keer zo groot als de realisatie. Ook bij de eerdere SKILLprognoses die zijn gebruikt voor de instroomprognoses tot 1992 was de fout bij het hoger Sociaal-Agogisch onderwijs relatief groot. Bij VBO technisch en WO technisch blijft de gerealiseerde instroom eveneens sterk achter bij de prognose. Bij WO technisch was dat ook bij eerdere SKILL-prognoses het geval, terwijl bij VBO technisch de instroom bij de eerdere prognoses juist werd onderschat. Erg goed zijn de voorspellingen voor het MAVO, HAVO en WWO.

In tabel 6.2 wordt een overzicht gegeven van de voorspelkwaliteit van de SKILLprognoses. Absoluut gezien is de kwaliteit van de SKILL-prognoses redelijk. De SKILL-prognose bevat $75 \%$ van de fout van de referentieprognose. Toch is de score sterk verslechterd ten opzichte van de eerdere SKILL-prognoses, tot 1992. Toentertijd was de score 0,22. Als wordt gecorrigeerd voor de algehele overschatting van het aantal gediplomeerden dan blijkt dat de referentieprognose het zelfs beter doet dan de SKILL-prognoses. De score komt dan op 1,15, bij de eerdere prognoses was dat nog 0,86. Geconcludeerd kan worden dat de kwaliteit van de SKILL-prognoses aanmerkelijk lager is dan bij de prognoses tot 1992 . Uit het

22. Omdat de classificatie in de Referentieraming niet geheel overeen komen met de classificatie die in SKILL werd gebruikt zijn enkele opleidingen samengevoegd. 


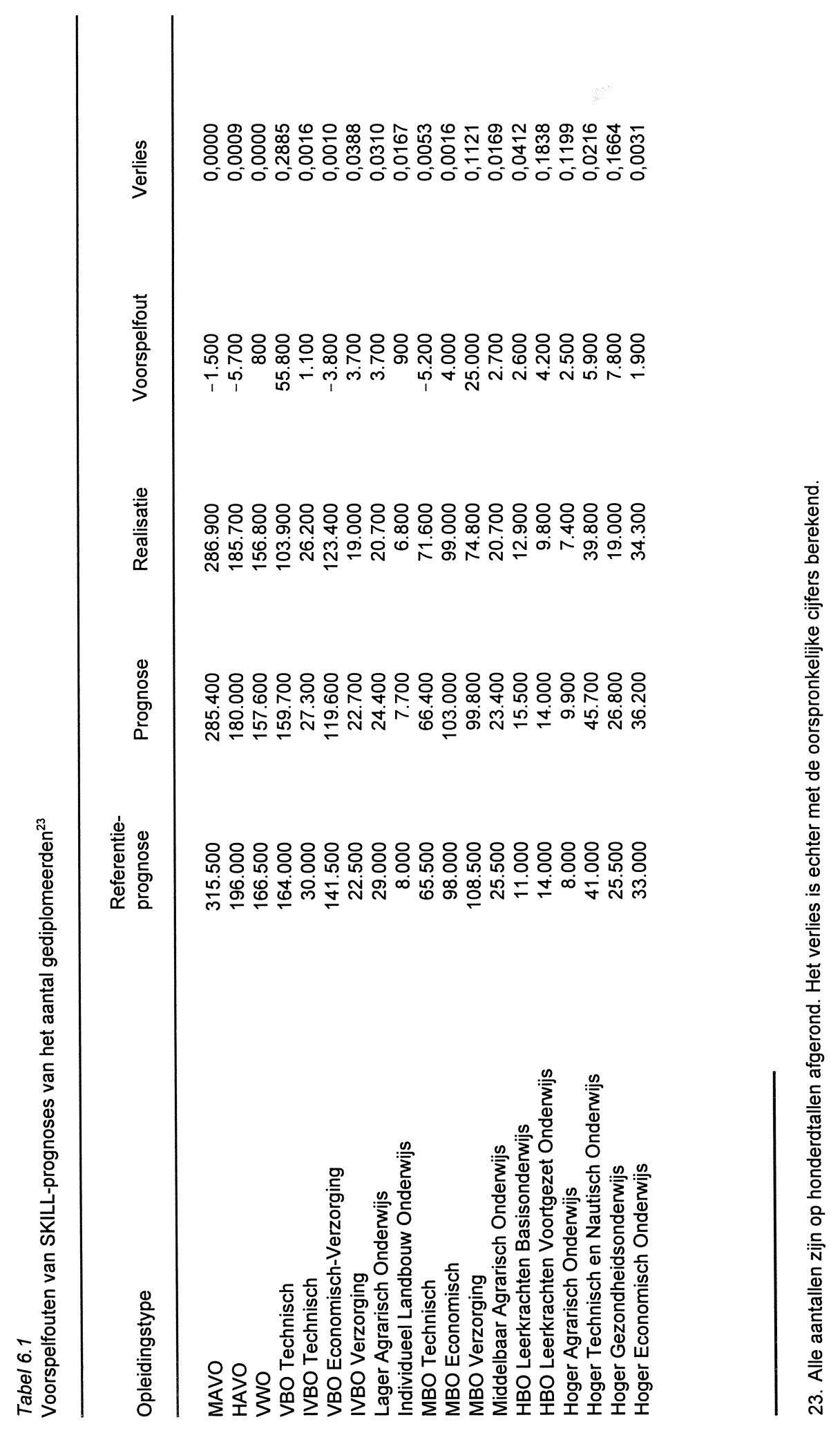




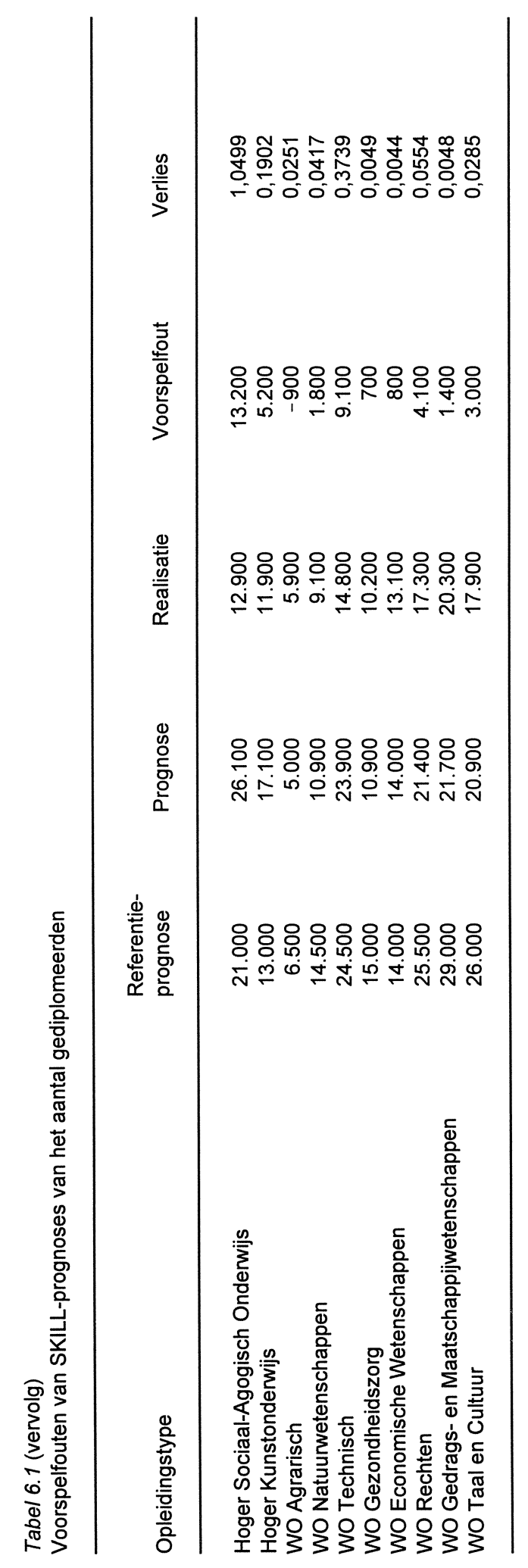


feit dat met name de absolute prognoses goed zijn vergeleken met de referentieprognose, blijkt dat vooral de onderwijsuitstroom als geheel wel vrij goed wordt voorspeld, maar de aandelen daarin van de diverse onderwijscategorieën daarbinnen veel slechter zijn voorspeld.

Tabel 6.2

Totaal-overzicht kwaliteit SKILL-prognoses van het aantal gediplomeerden

\begin{tabular}{llll}
\hline Methode & $\begin{array}{l}\text { Verlies } \\
\text { prognose }\end{array}$ & $\begin{array}{l}\text { Verlies } \\
\text { referentieraming }\end{array}$ & Score \\
\hline Prognoses 1994 & & & \\
Absoluut & 0,0496 & 0,0660 & 0,75 \\
Relatief & 0,0328 & 0,0285 & 1,15 \\
Pronoses tot 1992 & & & 0,86 \\
Relatief & 0,0122 & 0,0142 & 0 \\
\hline
\end{tabular}

Verklaring van de voorspelfouten

Ook voor de SKILL-prognoses is de voorspelfout geanalyseerd. Omdat er geen gegevens beschikbaar zijn over het aantal werkenden per opleiding volgens de SKILL-classificatie, is niet gekeken naar de invloed van de schaal op de nauwkeurigheid van de voorspellingen. Wel is nagegaan of er sprake is van over- of onderschatting van veranderingen. Uit tabel 6.3 blijkt dat er bij de relatieve prognoses sprake is van een gigantische overschatting van veranderingen. Bij de absolute prognoses is dit effect echter niet aanwezig. Dit laat opnieuw zien dat de SKILL-prognoses weliswaar een goede voorspelling geven van de totale uitstroom, maar dat de verdeling over de oplossingssoorten bijzonder slecht wordt voorspeld.

Tabel 6.3

Een verklaring van de voorspelfouten van de SKILL-prognoses (relatief)

\begin{tabular}{lrl}
\hline Variabele & Parameter & T-waarde \\
\hline Constante & 9,25 & $70,46^{* *}$ \\
Onderschattingscoëfficiënt & $-1,12$ & $-2,77^{*}$ \\
\hline
\end{tabular}

* significant bij betrouwbaarheid van $90 \%$

** significant bij betrouwbaarheid van $95 \%$ 
Zoals in de inleiding reeds is opgemerkt wordt de evaluatie van de prognoses van de arbeidsmarktinstroom per opleidingstype gecompliceerd door een tweetal factoren. Allereerst zijn er alleen realisaties van de ROA-arbeidsmarktinstroomprognoses beschikbaar vanaf 1990. De realisaties zijn bepaald op basis van gegevens uit de Referentie-Raming. De arbeidsmarktinstroom voor de periode 19981994 is bepaald door te veronderstellen dat de arbeidsmarktinstroom voor het schooljaar 1988/1989 gelijk is aan de arbeidsmarktinstroom 1989/1990. De referentieprognose wordt gelijk gesteld aan vijf maal de instroom van het schooljaar 1989/1990. ${ }^{24}$ Zoals opgemerkt in paragraaf 6.2 geeft de referentieraming direct informatie over de onderwijsuitstroom per opleiding zodat er geen tussenstap meer hoeft te worden gemaakt van de aantallen gediplomeerden naar onderwijsuitstroom op basis van de CBS-onderwijsmatrix. Daarnaast bevatten deze realisatiecijfers informatie uit bronnen die destijds niet beschikbaar waren en zijn deels de aannames over het niveau-verhogend karakter van het niet-regulier onderwijs aangepast. Dat betekent echter dat de referentieprognose feitelijk op betere data is gebaseerd dan de prognose zelf. Met name als de fout in de tussenstap, van aantallen gediplomeerden naar uitstroom of de invloed van verandering in de gemaakte aannames, relatief groot is zal de kwaliteit van referentieraming beter zijn dan van de prognose. Omdat er geen gegevens beschikbaar zijn over de verdeling van de ROA-instroomprognoses over de afzonderlijke prognosejaren is het echter onvermijdelijk dat de referentieprognose op de huidige gegevens is gebaseerd. Het enige alternatief als referentieprognose is de veronderstelling dat de arbeidsmarktinstroom proportioneel is aan de werkgelegenheid bij de betreffende opleidingstypen. Dit is echter een vrij zwakke referentieprognose die geen recht doet aan de structurele verschillen in arbeidsmarktinstroom tussen de diverse opleidingstypen.

Tabel 6.4 geeft een overzicht van de instroomprognoses per opleidingstype en de realisaties. Het grootste verlies doet zich voor bij de opleiding VBO agrarisch, de instroomprognose voor dit opleidingstype is ruim twee en half keer te hoog. Dit grote verschil wordt veroorzaakt doordat bij de prognoses voor 1994 door het ontbreken van de relevante cijfers, geen rekening is gehouden met het leerlingwezen in de agrarische beroepen. Bij MBO economisch en administratief wordt het verschil tussen beide instroomcijfers veroorzaakt door de wijze waarop het cursorisch ondernemersonderwijs in de informatie is verwerkt. Voor VBO verzorgend en MBO sociaal cultureel is de arbeidsmarktinstroom eveneens sterk overschot. Overigens

24. Dat betekent dus dat feitelijk alleen de instroomprognoses voor 1991-1994 worden geëvalueerd omdat de prognoses en de referentieraming voor 1989-1990 aan elkaar gelijk zijn. 


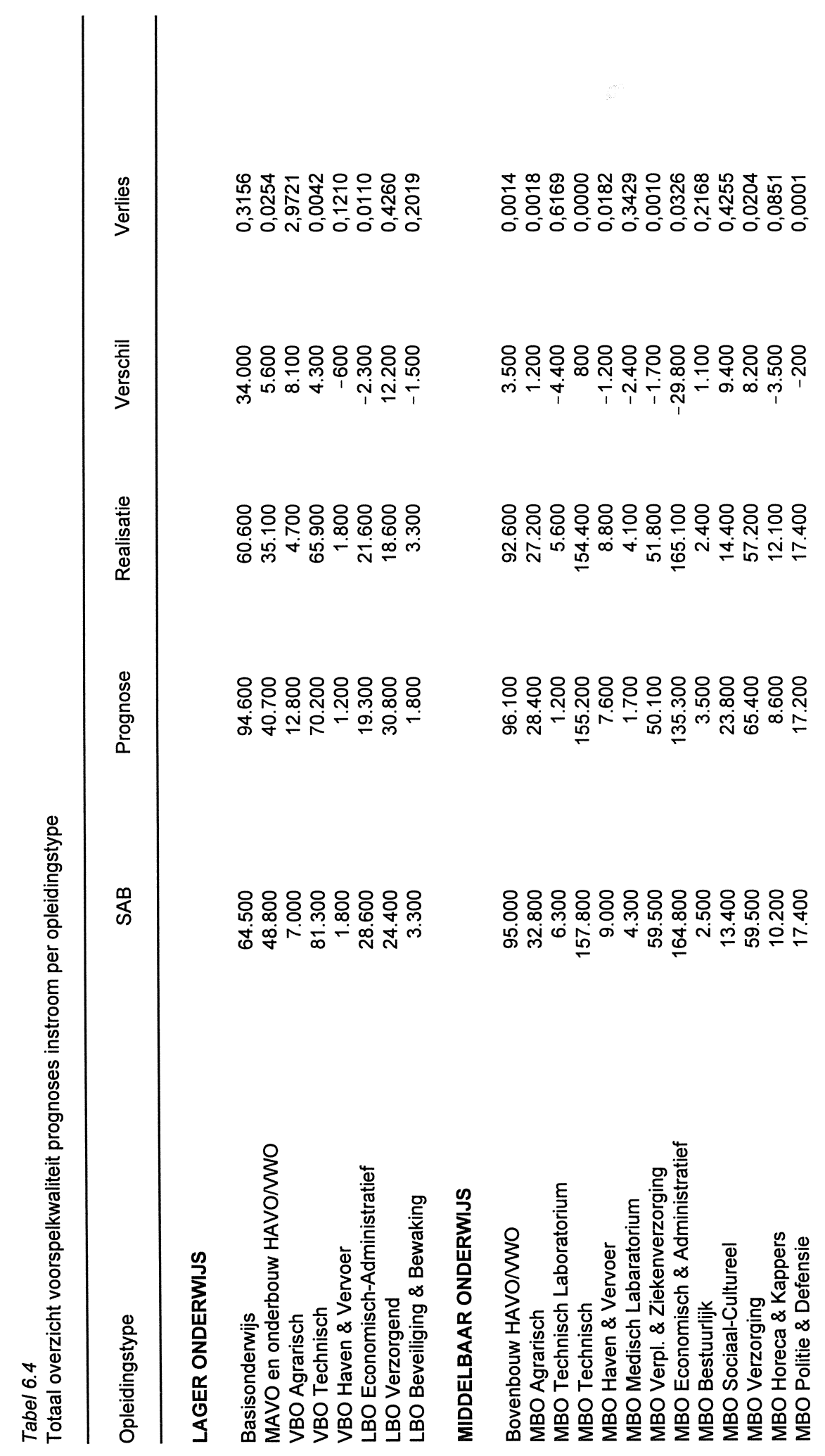




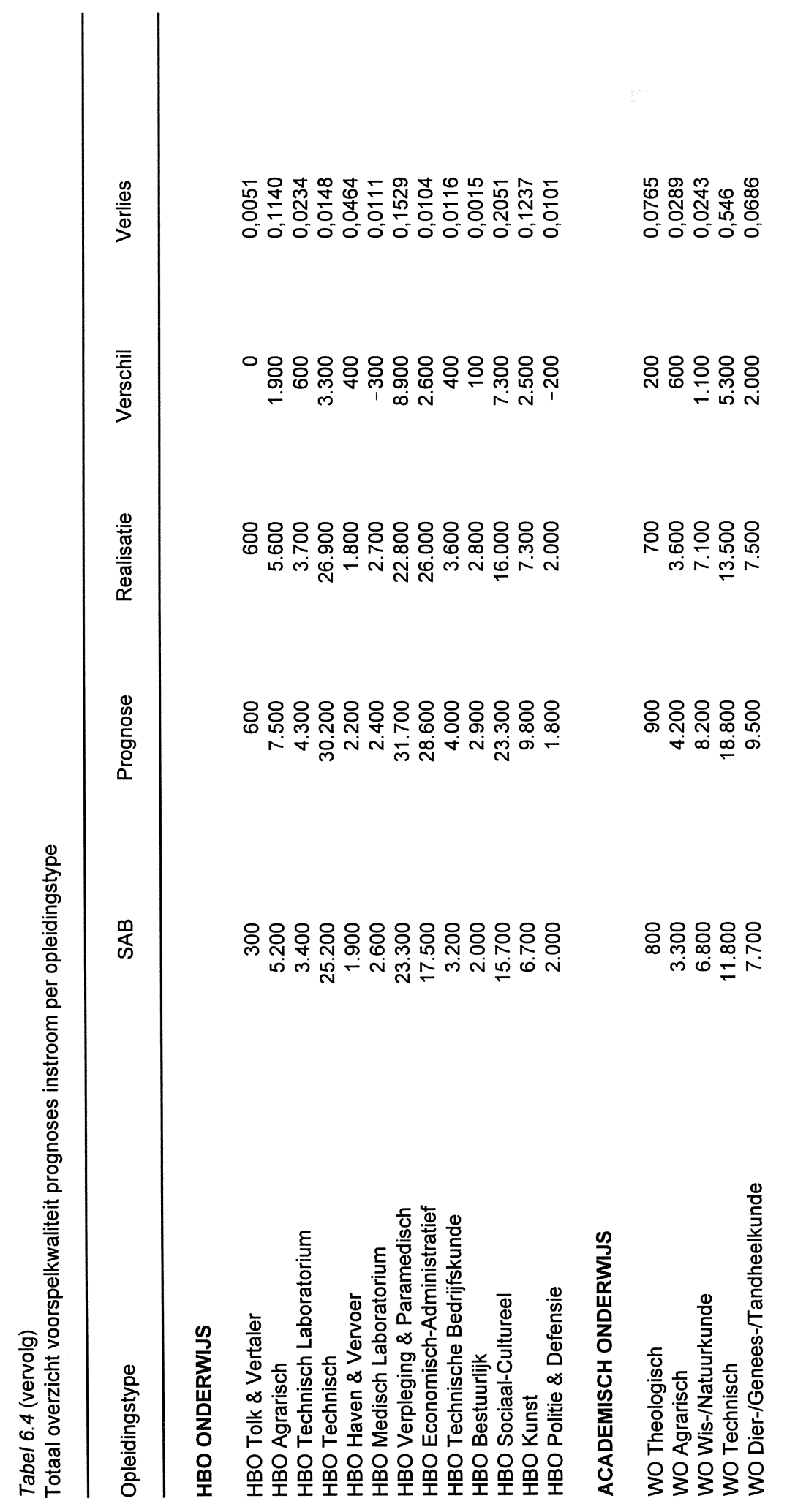




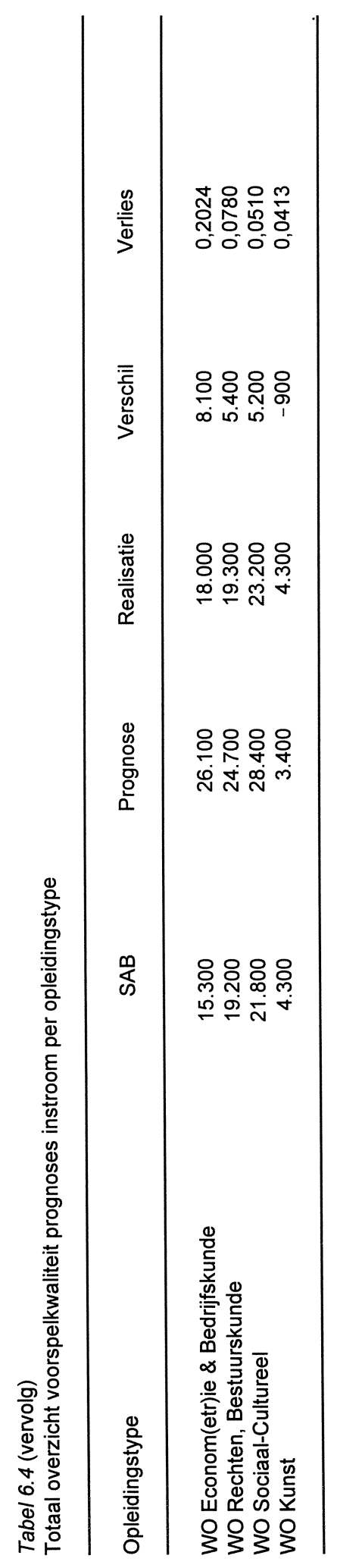


blijkt uit de tabel dat ook de totale arbeidsmarktinstroom behoorlijk is overschat. Dat betekent, omdat dit verschil niet werd aangetroffen bij de SKILL-prognoses, dat de doorstroom van gediplomeerde schoolverlaters naar vervolgopleidingen in het regulier voltijds-onderwijs is onderschat. Er zijn slechts enkele opleidingstypen waarbij de gerealiseerde arbeidsmarktinstroom hoger uitvalt dat de prognose. Een voorbeeld daarvan is de opleiding MBO technisch laboratorium. De realisatie is bij dit opleidingstype bijna vijf keer zo hoog als de prognose. Een opleiding waarvan de arbeidsmarktinstroom juist erg goed is voorspeld is MBO politie en defensie. Het gaat bij dit opleidingstype voornamelijk om niet reguliere opleidingen, zoals politieopleidingen en opleidingen tot beroepsmilitair. Er is voor de prognoses voor deze opleidingen gebruik gemaakt van aanvullend data-materiaal over de betreffende opleidingen.

In tabel 6.5 worden de instroomprognoses vergeleken met de referentieprognoses. Het blijkt dat voor de absolute prognoses het verlies van de referentieprognoses veel lager is dan voor de arbeidsmarktinstroomprognoses per opleidingstype. De score is 3,77 . De score van de relatieve prognoses is wat lager maar het verschil met de absolute prognoses is niet groot. Zoals gezegd kan de slechte score van de instroomprognoses per opleidingstype grotendeels worden verklaard uit het feit dat de referentieprognose is bepaald op basis van betere data die destijds nog niet beschikbaar was. Verder is de totale doorstroom op basis van de CBSondenwijsmatrix 1989 bepaald terwijl de doorstroom in werkelijkheid sterk is toegenomen. De score blijkt overigens vooral negatief beïnvloed te zijn door de slechte prognoses voor het basisonderwijs (marginale bijdrage aan de score is $0,85)$, VBO agrarisch, MBO economisch en administratief, MBO sociaal-cultureel en $\mathrm{HBO}$ verpleging en paramedisch. De invloed van de prognosefout bij VBO agrarisch is klein, omdat het een kleine groep betreft.

Een alternatief als referentieprognose zou, zoals reeds werd opgemerkt, de veronderstelling zijn dat de instroom gelijk is aan een vast percentage van het aantal werkzame personen met de betreffende opleidingsachtergrond. Deze referentieprognose is echter juist weer erg naïef, waardoor de score op 0,17 uit zou komen.

Tabel 6.5

Totaal overzicht voorspelkwaliteit prognoses instroom per opleidingstype aanbod

\begin{tabular}{llll}
\hline & Verlies & $\begin{array}{l}\text { Referentie- } \\
\text { gegeven }\end{array}$ & Score \\
\hline Absoluut & 0,0781 & 0,0207 & 3,77 \\
Relatief & 0,0585 & 0,0169 & 3,45 \\
\hline
\end{tabular}


Tabel 6.6 geeft een verklaring van de voorspelfouten en de standaardfout van de voorspelfouten van de arbeidsmarktinstroom. Het blijkt dat de standaardfout bijna evenredig toeneemt met de omvang van de totale werkgelegenheid per opleidingstype $^{25}$. Dit wijkt af van de gevonden resultaten voor de vraagprognoses. Bij zowel de uitbreidingvraag als de vervangingsvraag neemt de standaardfout duidelijk minder toe met de schaalomvang. Een belangrijke verklaring voor dit verschil is uiteraard dat de uitbreidingsvraag- en vervangingsvraagprognoses gebaseerd zijn op steekproefgegevens uit de EBB, terwijl de onderwijsstatistieken gebaseerd zijn op volledige tellingen.

Tabel 6.6

Verklaring van de voorspelfouten van de instroomprognoses (relatief)

\begin{tabular}{lcc}
\hline Variabele & Parameter & T-waarde \\
\hline Constante & 1,66 & $1,97^{\star \star}$ \\
Schaal & 0,81 & $10,60^{\star \star}$ \\
Onderschatting & $-0,81$ & $-17,90^{\star \star}$ \\
\hline
\end{tabular}

${ }^{\star \star}$ signifcant bij betrouwbaarheid van $95 \%$

Bovendien is er sprake geweest van een systematische overschatting van de arbeidsmarktinstroom. Deze overschatting is groter dan bij de uitbreidingsvraag- en vervangingsvraagprognoses. Overigens blijkt er sprake te zijn van correlatie tussen de schaal $\left(y_{i}\right)$ en de mate van overschatting. Als de voorspelfout niet gecorrigeerd wordt voor over- of onderschatting dan neemt de standaarddeviatie minder sterk toe met de schaal. Het overschattingseffect blijft echter significant. Deze bevindingen geven an dat met name voor de kleinere opleidingstypen de prognoses relatief veel veranderingen aangeven die in de realisaties niet teruggevonden worden.

\section{Kwalitatieve typeringen}

Ook de prognoses voor de arbeidsmarktinstroom zijn, om de interpreteerbaarheid te bevorderen, ingedeeld in een vijftal kwalitatieve typeringen. De indeling die hierbij is gehanteerd is als volgt:

25. Het gaat hier overigens om de werkgelegenheid per opleidingstype in 1990, omdat voor 1994 alleen cijfers beschikbaar zijn voor aantallen werkenden voor minstens 12 uur. 


$\begin{array}{rlllll} & & \text { INS } & \leq & 8 \% & \text { erg laag } \\ 8 \% & < & \text { INS } & \leq & 15 \% & \text { laag } \\ 15 \% & < & \text { INS } & \leq & 26 \% & \text { gemiddeld } \\ 26 \% & < & \text { INS } & \leq & 47 \% & \text { hoog } \\ 47 \% & < & \text { INS } & & & \text { erg hoog }\end{array}$

Tabel 6.7 geeft een overzicht van de realisatie van deze typeringen in relatie tot de voorspelde typeringen. Het blijkt dat 29 van de 43 opleidingstypen de juiste typering heeft gekregen. Dat is $67 \%$. Daarnaast is bij 13 opleidingstypen de kwalitatieve typering slechts één categorie naast de voorspelde typering. In totaliteit is derhalve voor $98 \%$ van de opleidingstypen een juist of vrijwel juiste kwalitatieve typering van de arbeidsmarktinstroom gegeven. Slechts in één geval was dit niet zo. Dit betreft het al eerder genoemde MBO technisch laboratorium. Voor dit opleidingstype werd een zeer lage arbeidsmarktinstroom voorzien, terwijl deze feitelijk gemiddeld bleek te zijn.

Tabel 6.7

Typeringen van de instroom per opleidingstype (relatief)

\begin{tabular}{lcccccc}
\hline & & \multicolumn{5}{c}{ Prognose } \\
Realisatie & erg laag & laag & gemiddeld & hoog & erg hoog & totaal \\
& & & & & & \\
\hline Erg laag & 2 & 4 & 0 & 0 & 0 & 6 \\
Laag & 0 & 6 & 0 & 0 & 0 & 6 \\
Gemiddeld & 1 & 1 & 13 & 3 & 0 & 18 \\
Hoog & 0 & 1 & 0 & 6 & 4 & 2 \\
Erg hoog & 0 & 0 & 0 & 1 & 1 & 43 \\
Totaal & 3 & 12 & 13 & 10 & 5 & \\
\hline
\end{tabular}

Deze resultaten tonen opnieuw dat de slechte score van de instroomprognoses met name veroorzaakt zijn door de onvergelijkbaarheid van de feitelijke prognose en de referentieprognose. De onderwijsstromen naar de arbeidsmarkt worden voldoende nauwkeurig voorspeld om in termen van kwalitatieve typeringen bevredigende voorspelresultaten te behalen.

\subsection{Conclusies}

Geconcludeerd kan worden dat de prognoses van de arbeidsmarktinstroom van schoolverlaters in termen van kwalitatieve typeringen een zeer betrouwbaar element zijn van de arbeidsmarktprognoses van het informatiesysteem. Net als bij de vorige prognoses blijken de prognoses van de uitstroom uit het initiële dagonderwijs die als 
uitgangspunt dienen met name de totale stromen goed te voorspellen, maar minder goed te scoren wat betreft de verdeling over de opleidingsrichtingen. Daarbij bevatten de SKILL-prognoses met name een sterke overschatting van veranderingen. Waarschijnlijk wordt te veel invloed toegekend aan de laatst waargenomen verdelingen over de richtingen. Onderzoek wijst uit dat slechts een deel van de jaarop-jaar-fluctuaties een structurele betekenis heeft.

Bij de verbijzondering van de SKILL-prognoses naar ROA-opleidingstypen speelt een vergelijkbaar probleem. Inmiddels is dit ondervangen door een modelaanpassing waarin zowel de eenmalige fluctuaties in de verdeelcoëfficiënten wordt uitgefilterd, als ook de structurele ontwikkeling wordt geëxtrapoleerd. Verder is het voor een verdere verbetering van de arbeidsmarktinstroomprognoses van belang dat met name voor het niet-reguliere onderwijs het inzicht in de onderwijsstromen wordt vergroot en er een betere afstemming komt tussen de onderwijsniveaucodering bij de EBB, waarop de vraagprognoses zijn gebaseerd, en de arbeidsmarktinstroomprognoses. 


\section{Confrontatie van vraag en aanbod}

\subsection{Inleiding}

De verhouding tussen de verwachte vraag- en aanbodstromen komt tot uitdrukking in de Indicator Toekomstige Arbeidsmarktsituatie (ITA). Deze indicator geeft de verwachte arbeidsmarktperspectieven per opleidingstype weer. Een slecht arbeidsmarktperspectief zal zich uiten in minder aantrekkelijke banen en eventueel een hogere werkloosheid. In dit hoofdstuk wordt met behulp van de schoolverlatersenquêtes RUBS en HBO-Monitor geëvalueerd of de voorspelde perspectieven daadwerkelijk tot uiting komen in de positie van de schoolverlaters op de arbeidsmarkt.

\subsection{De indicator toekomstige arbeidsmarktsituatie}

De arbeidsmarktperspectieven voor schoolverlaters voor de periode 1989-1994 zijn bepaald door de voorspelde vraag met het voorspelde aanbod per opleidingstype te confronteren. De totale vraag naar schoolverlaters is gelijk aan de som van de uitbreidingsvraag en de vervangingsvraag per opleidingstype. Het voorspelde aanbod per opleidingstype bestaat uit de voorspelde arbeidsmarktinstroom en het aantal kortdurige werklozen met het betreffende opleidingstype aan het begin van de prognoseperiode. Er is verondersteld dat alleen kortdurige werklozen met schoolverlaters concurreren. Van langdurig werklozen wordt aangenomen dat ze op de arbeidsmarkt geen serieuze concurrentie voor de schoolverlaters vormen.

De indicator toekomstige arbeidsmarktsituatie (ITA), die is gehanteerd voor de kwalitatieve typering van de arbeidsmarktperpectieven naar opleidingstype voor 1994 , is gedefinieerd als het quotiënt van de som van totale werkgelegenheid en het aanbod en de som van de totale werkgelegenheid en de vraag per opleidingstype. Naarmate de waarde van de ITA hoger is, is het arbeidsmarktperspectief voor de betreffende opleiding slechter. Deze indicator wijkt af van de arbeidsmarktindicator (AMI) die werd gebruikt voor de prognoses tot 1992. De AMI is gedefinieerd als het quotiënt van vraag en aanbod. Deze indicator was echter tamelijk instabiel. Relatief kleine schommelingen in de vraag of aanbod prognoses hadden grote invloed op de waarde van de AMI. Daarom is er voor gekozen zowel in de teller als in de noemer de totale werkgelegenheid van het betreffende opleidingstype op te tellen. Een ander verschil tussen de ITA en de AMI is dat bij de AMI alleen werd gekeken naar de instroom per opleidingstype en het aantal kortdurige werklozen aan het begin van de prognoseperiode nog werd genegeerd.

Bij latere prognoses is de definitie van de ITA overigens nog enigszins aangepast. Ten eerste wordt bij de meest recente prognoses alleen de positieve uitbreidingsvraag meegeteld bij het bepalen van de totale vraag naar nieuwkomers. De 
reden hiervoor is dat bij de vervangingsvraagprognoses al rekening is gehouden met een negatieve uitbreidingsvraag. Verder werd in hoofdstuk 3 al opgemerkt dat discrepanties tussen vraag en aanbod op de arbeidsmarkt leiden tot verschuivingen in de vraag. Als het aanbod van een opleidingstype groter is dan de vraag zal de arbeidsmarktpositie van deze opleiding verslechteren. Dat leidt er toe dat nieuwkomers moeten uitwijken naar voor hen minder aantrekkelijke banen. Ze verdringen daarbij nieuwkomers uit andere opleidingen. Aan de andere kant leiden tekorten bij een bepaald opleidingstype juist tot extra vraag naar arbrbeidskrachten met een andere opleidingsachtergrond. Het arbeidsmarktperspectief van een opleiding is dus ook afhankelijk van discrepanties tussen vraag en aanbod bij verwante opleidingen. De substitutievraag is de vraag naar schoolverlaters met een bepaalde opleidingsachtergrond als gevolg van tekorten of overschotten bij andere opleidingstypes. Tegenwoordig wordt bij het berekenen van de ITA ook rekening gehouden met deze substitutievraag (zie ook Borghans en Heijke, 1996 en Borghans, De Grip en Willems, 1995).

\subsection{Evaluatie van de toekomstige arbeidsmarktperspectieven}

De ITA geeft een indicatie van het arbeidsmarktperspectief voor een opleidingstype. Zoals reeds eerder is opgemerkt leidt een aanbodoverschot van een opleidingstype niet zonder meer tot werkloosheid voor nieuwkomers. Slechte perspectieven kunnen er ook toe leiden dat mensen vaker onder hun niveau gaan werken, genoegen nemen met een tijdelijk contract, of een lager loon accepteren. Het is dus niet voldoende om alleen naar de werkloosheid te kijken. Ook andere facetten van de arbeidsmarktpositie van schoolverlaters zijn van belang bij de evaluatie van de ITA.

Omdat de ITA aangeeft hoe de arbeidsmarktpositie van een opleiding zich ontwikkelt ten opzichte van de situatie in het basisjaar, zou de ITA ook moeten worden geëvalueerd door per opleidingstype de arbeidsmarktpositie in 1994 met de arbeidsmarktpositie in 1989 te vergelijken. Er is echter geen goede informatie beschikbaar over de arbeidsmarktpositie van schoolverlaters in 1989. Voor 1994 kan gebruik worden gemaakt van de schoolverlatersenquêtes, HBO-monitor en RUBS ${ }^{26}$. Daarom wordt niet per opleiding naar de ontwikkelingen in de arbeidsmarktpositie over de periode 1989 tot en met 1994 gekeken, maar wordt de arbeidsmarktpositie tussen de opleidingstypen in 1994 geanalyseerd. Er wordt hiermee impliciet verondersteld dat alle opleidingen op dezelfde manier op arbeidsmarktdiscrepanties reageren. Op basis van gegevens uit RUBS en HBO-monitor wordt voor verschillen-

26. De RUBS-schoolverlatersenquête is ook al in 1989 gehouden. Door verschillen tussen de enquêtes van 1989 en 1994 is het echter niet mogelijk om betrouwbare vergelijkingen tussen beide jaren te maken. 
de aspecten van de arbeidsmarktpositie de relatie met de ITA geschat ${ }^{27}$. De volgende arbeidsmarktaspecten zijn daarbij in beschouwing genomen (zie ook Wieling en Borghans, 1995): Het werkloosheidspercentage op het moment van enquête, het percentage schoolverlaters dat langer dan 4 maanden werkloos was na het verlaten van de opleiding, het percentage schoolverlaters dat wordt onderbenut, het percentage schoolverlaters met vast werk het percentage schoolverlaters met deeltijdwerk $^{28}$, en het percentage schoolverlaters dat een relatief laag loon verdient ${ }^{29}$. Per aspect is de volgende vergelijking geschat:

$y_{i}^{k}=\alpha^{k}+\beta^{k} *\left(I T A_{i}-1\right)$

Waar:

$y_{i}^{k}=$ arbeidsmarktaspect $k$ voor opleidingstype $i$.

Door in de vergelijking de ITA te relateren aan de situatie waarin vraag en aanbod elkaar in evenwicht houden (ITA=1), kan $\alpha^{k}$ geïnterpreteerd worden als de 'natuurlijke 'omvang van de betreffende indicator. $\beta^{k}$ geeft aan hoe de indicator wijzigt als gevolg van veranderende perspectieven. Tabel 7.1 geeft de uitkomsten van de afzonderlijk schattingen ${ }^{30}$. Het blijkt dat er sprake is van een positieve relatie tussen de ITA en het werkloosheidpercentage. Het effect is echter niet significant. Dat geldt eveneens voor het percentage schoolverlaters dat langer dan 4 maanden werkloos is geweest na afstuderen. Naarmate het verwachte toekomstige arbeidsmarktperspectief slechter was, is het in 1994 waargenomen percentage onderbenutting ook hoger. Ook het percentage deeltijdwerkers neemt toe als de ITA hoger is. Het percentage dat vast werk heeft neemt, zoals verwacht, juist af naarmate het toekomstig arbeidsmarktperspectief slechter was. Het percentage schoolverlaters met een laag loon is negatief gecorreleerd met de ITA, maar ook dit effect is niet significant. Geconcludeerd kan worden dat discrepanties tussen vraag

27. $\mathrm{Er}$ is alleen informatie beschikbaar voor schoolverlaters van $\mathrm{AVO}, \mathrm{VBO}, \mathrm{MBO}$ en $\mathrm{HBO}$. De ITA kan dus niet worden geëvalueerd voor WO-opleidingen en het basisonderwijs.

28. Deeltijdwerk hoeft op zich natuurlijk niet onvrijwillig te zijn. Het kan ook een door de schoolverlater gewenste situatie betreffen. Omdat het percentage deeltijdwerkers wordt gecorreleerd met het arbeidsmarktperspectief gaat het hier alleen om de variatie in deeltijdwerk die wel vanuit de arbeidsmarktsituatie kan worden verklaard.

29. Er is sprake van een relatief laag loon, als het loon lager is dan $\mu-0,524 * \sigma$, waar $\mu$ het gemiddelde loon van schoolverlaters met het betreffende opleidingsniveau en de standaard-deviatie (zie Wieling, De Grip, en Willems, 1990).

30. In feite is hier sprake van een stelsel van vergelijkingen, dat simultaan geschat zou kunnen worden. Een mogelijke correlatie tussen de storingstermen, dat wil zeggen $E\left[\varepsilon_{j}^{k} \varepsilon_{j}^{\prime}\right]=\sigma_{k l}$, heeft echter geen invloed op de schattingsresultaten, omdat de regressoren voor alle vergelijkingen gelijk zijn. 
en aanbod inderdaad niet per se tot werkloosheid leiden, maar dat een slechtere arbeidsmarktpositie zich vooral uit in meer onderbenutting en meer deeltijdwerk. Dit resultaat bevestigt de bevindingen van Wieling en Borghans (1995).

Tabel 7.1

Relatie tussen voorspelde arbeidsmarktpositie en huidige arbeidsmarktsituatie

\begin{tabular}{lrrrr}
\hline Indicator arbeidsmarktsituatie & $\alpha$ & T-waarde & $\beta$ & T-waarde \\
\hline & & & & \\
Werkloos & 0,10 & $8,96^{* *}$ & 0,04 & 0,45 \\
$>4$ maanden werkloos na afstuderen & 0,16 & $10,92^{* *}$ & 0,08 & 0,69 \\
Onderbenutting & 0,27 & $9,75^{* *}$ & 0,38 & $1,83^{*}$ \\
Deeltijdwerk & 0,34 & $7,71^{* *}$ & 0,73 & $2,25^{* *}$ \\
Vast werk & 0,57 & $20,34^{* *}$ & $-0,20$ & 0,94 \\
Laag loon & 0,22 & $8,91^{* *}$ & $-0,00$ & 0,03 \\
& & & & \\
\hline
\end{tabular}

* significant bij betrouwbaarheid van $90 \%$

** signifcant bij betrouwbaarheid van $95 \%$

Om te bepalen hoe goed de ITA de toekomstige arbeidsmarktsituatie heeft voorspeld moeten alle aspecten van deze arbeidsmarktsituatie simultaan worden beschouwd. Daarom is een regressievergelijking geschat waarin de ITA wordt verklaard uit bovengenoemde indicatoren van de arbeidsmarktsituatie ${ }^{31}$. Op basis van deze vergelijking zijn de realisaties van de ITA bepaald. De $\bar{R}^{2}$ van deze schatting kan vergeleken worden met de score-verhouding volgens score $=1-\bar{R}^{2}$ Omdat de $\vec{R}^{2} 0,20$ is zou de op deze wijze berekende score $0,80 \mathrm{zijn}$. Bij de vorige prognoses voor 1992 was deze score 0,91 . Tabel 7.2 geeft een vergelijking van de prognose en de realisatie van de kwalitatieve typeringen van het arbeidsmarktperspectief. Hierbij moet echter wel bedacht worden dat de vergelijking die het gewicht van de diverse indicatoren van de arbeidsmarktsituatie bepaalt, geschat is op basis van de prognoses. $\mathrm{Er}$ is verondersteld dat de voorspelfouten een verwachting van 0 hebben. Niet alleen de prognoses maar ook de geschatte realisaties bevatten onzekerheid. Discrepanties tussen prognose en realisatie kunnen daarom ook de

31. Deze resulterende vergelijking is de volgende:

ITA $A_{i}=0,75+0,52 *$ wlh $4_{i}+0,28 *$ benut $_{i}+0,25 *$ deeltijd $_{i}+0,06 *$ vast $_{i}-0,01 *$ laagloon $_{i}$ waar ITA, de indicator toekomstig arbeidsmarktperspectief tot 1994 voor opleidingstype $i$ is, wh $4_{i}$ het percentage schoolverlaters dat langer dan 4 maanden werkloos is na afstuderen, benut $_{i}$ het percentage schoolverlaters dat wordt onderbenut, deeltijd ${ }_{i}$ het percentage schoolverlaters dat deeltijd werk heeft, vast ${ }_{i}$ het percentage schoolverlaters met vast werk en laagloon ${ }_{i}$ het percentage schoolverlaters met een laag loon. Vergeleken met vergelijking (12) zijn de verklarende en de te verklaren variabele hier verwisseld. Het gaat hier dan ook niet om een causaal verband, maar om de mate waarin afzonderlijke indicatoren informatie geven over de meest aannemelijke waarde van de niet direct waargenomen 'realisatie' van de ITA. 
oorzaak zijn van een onnauwkeurige bepaling van de gerealiseerde perspectieven.

Tabel 7.2

Typering van de arbeidsmarktindicator ITA en de geschatte realisaties

\begin{tabular}{lccccc}
\hline & \multicolumn{5}{c}{ Realisaties } \\
Prognose & Goed & Redelijk & Matig & Slecht & Totaal \\
\hline Goed & 8 & 5 & 0 & 1 & 14 \\
Redelijk & 1 & 1 & 3 & 0 & 5 \\
Matig & 1 & 3 & 1 & 0 & 5 \\
Slecht & 0 & 1 & 2 & 4 & 7 \\
Totaal & 10 & 10 & 6 & 5 & 31 \\
\hline
\end{tabular}

Uit de tabel blijkt dat de voorspelde typeringen van de arbeidsmarktperspectieven van de diverse opleidingstypen vrij goed zijn geweest. Bij 14 van de 31 opleidingstypen waarvan informatie over de huidige arbeidsmarktpostie beschikbaar is, komt de kwalitatieve typering van de prognose exact overeen met de realisatie ${ }^{32}$. Dat is ongeveer $45 \%$ van de opleidingstypen. Als ook de opleidingstypen die slechts één categorie naast de gerealiseerde categorie zijn voorspeld worden meegerekend, dan blijkt dat voor ongeveer $90 \%$ van de opleidingstypen de toekomstige arbeidsmarktpositie redelijk goed getypeerd is. Slechts bij twee opleidingstypen wijst de realisatie in een tegengestelde richting als de prognose. Voor de opleiding MBO verzorgend werd een goed arbeidsmarktperspectief voorspeld, terwijl de realisatie slecht was. Voor HBO agrarisch werd juist een slecht perspectief voorspeld, terwijl de realisatie redelijk is.

De kwaliteit van de prognoses van de arbeidsmarktperspectieven tot 1994 is ook duidelijk verbeterd vergeleken met de prognoses van de perspectieven tot 1992 . Uit de evaluatie van de prognoses tot 1994 bleek dat toentertijd voor ongeveer $70 \%$ van de opleidingen het arbeidsmarktperspectief redelijk goed voorspeld was. Naast de verbeterde vraag- en aanbodprognoses is ook de andere berekeningswijze van de perspectieven een mogelijke verklaring voor deze verbetering. Zoals reeds werd opgemerkt in de vorige paragraaf was de AMI veel gevoeliger voor kleine schommelingen in de vraag- en aanbodprognoses dan de ITA. Wel moet bedacht worden dat de realisaties van de prognoses nu beter gemeten kunnen worden dan

32. Zoals gezegd is onvoldoende informatie beschikbaar over de actuele arbeidsmarktpostie van afgestudeerden van het WO. De prognoses van de arbeidsmarktperspectieven kunnen voor het WO daarom niet worden geëvalueerd. 
bij de evaluatie van 1992 omdat nu meer gegevens over de actuele arbeidsmarktpositie van schoolverlaters beschikbaar zijn.

\subsection{Conclusies}

Hoewel sommige onderdelen van de prognoses niet voor alle beroepen of opleidingen even bevredigend waren, blijken de arbeidsmarktperspectieven voor opleidingen toch vrij goed voorspeld te zijn. Dat komt ondermeer doordat voorspelfouten in een bepaald onderdeel vaak worden opgeheven door voorspelfouten in een ander onderdeel. De voorspelfouten in verschillende onderdelen zijn namelijk veelal negatief gecorreleerd. Bovendien lijken de prognoses per opleidingstype beter te zijn dan de prognoses per beroepsklasse. Niet alle fouten in de prognoses per beroepsklasse werken door in de prognoses per opleiding. Ook zijn zowel de arbeidsmarktinstroom als de vervangingsvraag twee componenten met een hoge betrouwbaarheid. Onzekerheden in de uitbreidingsvraag zijn veelal niet dermate groot dat ze de vrij robuuste balans van de eerstgenoemde twee prognosecomponenten kunnen doen omslaan. 


\section{Een vergelijking met de uitbreidingsvraag- prognoses van BLS}

\subsection{Inleiding}

Ook in andere westerse landen worden vergelijkbare arbeidsmarktprognoses opgesteld op een relatief laag aggregatieniveau. Deze prognose-activiteiten lopen sterk uiteen qua methodiek en aggregatieniveau. Binnen de Europese Unie wordt naast Nederland, ook in het Verenigd Koninkrijk door het Institute of Employment Research (IER), Duitsland door het Institut für Arbeitsmarkt- und Berufsforschung (IAB) en sinds kort lerland door het Economic and Social Research Institute (ESRI) wetenschappelijk onderbouwd, dergelijke prognoses gemaakt ${ }^{33}$. Buiten de EU vormen de prognoseactiviteiten van het Bureau of Labor Statistics (BLS) in de Verenigde Staten het belangrijkste voorbeeld op dit gebied. In tegenstelling tot het ROA stellen de meeste instituten alleen voorspellingen op van de werkgelegenheidsontwikkeling naar beroepsklasse. Dat betekent dat doorgaans geen prognoses per opleidingstype beschikbaar zijn, en ook de vervangingsvraag niet wordt voorspeld. Alleen het BLS stelt sinds kort, net als het ROA, ook vervangingsvraagprognoses op, terwijl het IER dit onlangs in een speciale studie van de arbeidsmarkt van academici deed.

In de Employment Outlook 1994 vergelijkt de OECD (1994) de voorspelde ontwikkelingen tussen de diverse landen en worden de prognoses uit het verleden geëvalueerd. Daarbij worden alle prognoses rechtstreeks met elkaar vergeleken, zonder rekening te houden met verschillen in prognosetermijn, aggregatieniveau en dergelijke. Het is echter evident dat zulke verschillen grote invloed hebben op de voorspelkwaliteit. Ook kan de kwaliteit van de beschikbare data van land tot land verschillen, hetgeen zijn uitwerking zal hebben op zowel de kwaliteit van de prognoses als de kwaliteit van de evaluatiecijfers. Om greep te krijgen op de oorzaken van verschillen in de prognosekwaliteit moeten de prognoses daarom op een systematische wijze worden vergeleken. In dit hoofdstuk wordt getracht hiervoor een eerste aanzet te geven door een vergelijking te maken tussen de ROAprognoses voor 1994 en de BLS-prognoses voor 1975, 1980 en 1990. Dit gebeurt op een vergelijkbare wijze als waarop in de hoofdstukken 3 en 4 de prognoses van de uitbreidingsvraag en de vervangingsvraag per beroepsklasse zijn vergeleken. Dat wil zeggen dat de prognoseresultaten worden vergeleken met de (SAB) referentieprognose en dat onderzocht wordt in hoeverre de verschillen voortkomen uit schaalverschillen en verschillen vanwege de gehanteerde classificatie.

33. Zie voor een overzicht Heijke (1993), Hughes (1993) en van Eijs (1994). 


\subsection{Arbeidsmarktprognoses van BLS}

$\mathrm{Na}$ de tweede wereldoorlog startte het US-Department of Labor met activiteiten om te bevorderen dat de veteranen die terugkeerden van het front zo snel mogelijk weer werk zouden vinden. Deze activiteiten werden ondergebracht bij het Bureau of Labor Statistics (BLS). Een van de activiteiten die het BLS ondernam was het opstellen van prognoses van de werkgelegenheid per beroep. Dit had met name als doel beslissingen over bijscholingsactiviteiten te kunnen onderbouwen. Na verloop van tijd werden deze gegevens eveneens voor andere doelgroepen gebruikt, omdat werd ingezien dat ook voor de studie- en beroepskeuzevoorlichting in het algemeen arbeidsmarktgegevens van grote waarde kunnen zijn. Dit resulteerde in een omvangrijk tweejaarlijks Occupational Outlook Handbook, (zie bv. BLS, 1984) waarin naast een grote hoeveelheid inhoudelijke informatie per beroepsgroep ook telkens de verwachte arbeidsmarktontwikkelingen worden geschetst.

Het BLS stelt zowel prognoses op die betrekking hebben op een hoog aggregatieniveau, als prognoses met een grote mate van detail. In dit hoofdstuk wordt ingegaan op deze gedetailleerde voorspellingen, omdat deze qua karakter het beste met de ROA-prognoses van de uitbreidingsvraag per beroepsklasse vergeleken kunnen worden. Bishop en Carter (1991) evalueren de prognose op hoog aggregatieniveau en ook het BLS zelf evalueert systematisch al haar prognoses (Carey, 1980, Carey en Kasunic, 1982 en Rosenthal, 1992).

Tabel 8.1 geeft een overzicht van de voorspelkwaliteit van de verschillende vraagprognoses per beroep van het BLS. Het gaat om uitbreidingsvraagprognoses per beroep voor de perioden 1960-1975, 1970-1980 en 1980-1990. Een belangrijk onderscheid tussen de ROA- en BLS-prognoses is dat het BLS een langere prognosetermijn kent, en verder een veel groter aantal beroepsklassen en bedrijfssectoren onderscheidt. Dit aantal groeide sinds 1960 met 162 beroepsklassen en 124 bedrijfssectoren tot tegenwoordig met 500 beroepsklassen en 250 bedrijfssectoren ${ }^{34}$. De bruikbaarheid van een dergelijke detaillering, met name met betrekking tot de bedrijfsklassen wordt betwijfeld. De prognosemethodiek van het BLS berust echter sterk op de bedrijfssectorprognoses. Bij de eerste prognoses (tot 1975 en tot 1980) werd in de beroepenstructuur van deze sectoren alleen een trendterm of een eenvoudig model dat de trend verklaart opgenomen, terwijl bij de prognoses tot 1990 vrijwel een vasten-coëfficiënten-model werd gehanteerd, waarin

34. Overigens is de evaluatie in dit hoofdstuk net als in de OECD-studie en de evaluaties van BLS uitgevoerd met slechts een deel van deze beroepsklassen. Voor een groot aantal beroepsklassen heeft er een verandering in de classificatie plaatsgevonden waardoor evaluatie niet meer mogelijk is. Het valt te verwachten dat deze groep beroepsklassen aselect is. 
de trendmatige ontwikkeling van de beroepenstructuur doorgaans werd genegeerd. Dit gebeurde op grond van de ervaringen opgedaan in de evaluaties van de eerdere prognoses, waarin een vasten-coëfficiëntenmodel beter voorspelde dan een trendmodel. Wel worden veelvuldig bijstellingen gemaakt in de beroepenverdeling van bedrijfssectoren op basis van de zeer kwalitatieve oordelen van deskundigen binnen het BLS.

De tabel laat zien dat met name de prognoses tot 1975 vrij goed zijn geweest. Het gemiddeld verlies van de eerste prognoses is lager dan van de prognoses voor 1980 en 1990. Dat is opmerkelijk, omdat bij de eerste prognoses de prognoseperiode veel langer is geweest. Het gemiddeld verlies van de SAB-referentieprognose is, zoals verwacht mocht worden, door deze langere prognoseperiode juist hoger dan bij de latere prognoses. Naarmate de prognoseperiode langer is zal, vooral als er sprake is van trendmatige ontwikkelingen, het gemiddeld verlies van SAB immers toenemen. De prognoses zelf hebben niet dit hogere gemiddeld verlies. Een belangrijke oorzaak hiervan blijkt te zijn dat de betreffende prognoses, hoewel ze 1960 als basisjaar hebben, pas later zijn opgesteld en er nog data uit 1965 is gebruikt. Daarenboven is het gemiddeld verlies voor deze tienjaarsperiode lager dan bij de latere prognoses. De goede score voor 1970 wordt dus zowel verklaard door het hoge verlies van $\mathrm{SAB}$ als door het opvallend lage verlies van de prognose. De prognoses tot 1980 hebben een hoger gemiddeld verlies. Het gemiddeld verlies van SAB reduceert daarentegen met meer dan $33 \%$. Het BLS signaleert zelf ook een lichte teruggang in de prognoseresultaten. De methodiek is in hoofdlijnen echter ongewijzigd. De toename van het aantal onderscheiden bedrijfsklasses kan de voorspelkwaliteit echter hebben verminderd.

In een analyse van de voorspelfouten constateert het BLS zelf dat het extrapoleren van trends in de beroepenstructuur geen betere prognoses opleverde dan de aanname dat de beroepenstructuur constant blijft. (Carey en Kasumic, 1982). Daarom stapt het over op een methode waarin trends alleen geëxtrapoleerd worden als er duidelijke aanwijzingen zijn dat de geconstateerde ontwikkelingen zicht voort zullen zetten. Bij de prognoses die, volgen deze methodiek, zijn gemaakt voor 1990 neemt zowel het gemiddeld verlies van de prognoses als van SAB toe. Daardoor is de score voor de prognoses tot 1990 ongeveer gelijk aan de score voor de prognoses tot 1980 , namelijk 0,70 . Per saldo levert de methodiekverandering dus geen verbetering op. Zelf constateert het BLS dat de prognoses voor 1990 te conservatief waren (Rosenthal, 1992). Door het niet opnemen van de trends is er volgens BLS sprake van wat in dit rapport een onderschatting van veranderingen wordt genoemd. Dit effect wordt echter door BLS niet systematisch geanalyseerd. 
Tabel 8.1

De voorspelkwaliteit van de prognoses van BLS (relatief)

\begin{tabular}{llll}
\hline & $\begin{array}{l}\text { Gem. verlies } \\
\text { prognose }\end{array}$ & $\begin{array}{l}\text { Gem. verlies } \\
\text { SAB }\end{array}$ & Score \\
\hline Tot 1975 & 0,0295 & 0,0981 & 0,30 \\
Tot 1980 & 0,0371 & 0,0527 & 0,70 \\
Tot 1990 & 0,0472 & 0,0654 & 0,72 \\
\hline
\end{tabular}

De mate van onder- of overschatting van veranderingen wordt weergegeven in tabel 8.2. Het blijkt echter dat zowel bij de prognose voor 1975 als voor 1990 absoluut gezien sprake was van systematische overschatting van veranderingen. Bij de relatieve prognoses wordt deze overschatting echter niet aangetroffen, wat betekent dat de voornaamste oorzaak gelegen is in een algehele overschatting van de werkgelegenheidsgroei. De door het BLS geconstateerde onderschatting van veranderingen wordt dus niet aangetroffen. Met betrekking tot de relatieve prognoses zijn de BLS-prognoses in dit opzicht derhalve beter te noemen dan de ROA-prognoses van de uitbreidingsvraag, waarin wel een duidelijke overschatting wordt aangetroffen. Dit verschil ligt aan de ene kant voor de hand gezien de eenvoudige voorspelmethodiek van het BLS, maar aan de andere kant zou juist vanwege het grote aantal bijstellingen op grond van oordelen van deskundigen een aanmerkelijk hoeveelheid ruis in de prognoses verwacht kunnen worden. Dit blijkt niet het geval te zijn.

Tabel 8.2

Over- of onderschatting prognoses BLS

\begin{tabular}{lcccc}
\hline Prognoses & $\begin{array}{l}\text { Absoluut } \\
\text { Onderschatting }\end{array}$ & T-waarde & $\begin{array}{l}\text { Relatief } \\
\text { Onderschatting }\end{array}$ & T-waarde \\
\hline Tot 1975 & $-0,09$ & 1,43 & 0,03 & 0,47 \\
Tot 1980 & $-0,08$ & 0,49 & 0,17 & 0,83 \\
Tot 1990 & $-0,49$ & $4,58 *$ & 0,04 & 0,34 \\
\hline
\end{tabular}

${ }^{*}$ significant bij betrouwbaarheid van $90 \%$

$\star \star$ signifcant bij betrouwbaarheid van $95 \%$

\subsection{Verschillen in voorspelkwaliteit tussen ROA en BLS}

Het vergelijken van de voorspelkwaliteit van de ROA-arbeidsmarktrpgnoses met de BLS-prognoses wordt bemoeilijkt door het het grote verschil in de omvang van totale beroepsbevolking tussen Nederland en de Verenigde Staten. Als schaal de enige 
factor is die de kwaliteit van de prognoses zou beïnvloeden, dan kunnen verschillen in voorspelkwaliteit ontstaan, door het absolute schaalverschil, vanwege het feit dat de beroepsbevolking in de V.S. veel omvangrijker is dan in Nederland, of juist door de relatieve schaal, doordat het BLS meer beroepen onderscheidt dan ROA. Voor het vergelijken van de kwaliteit van de voorspelmethodiek ligt een vergelijking van de absolute schaal voor de hand, omdat deze de omstandigheden weerspiegelt waaronder in beide landen prognoses moeten worden opgesteld. Voor de informatieve waarde van de prognoses ligt echter wellicht een vergelijking van de relatieve schaal voor de hand. Voor bijvoorbeeld studie- en beroepskeuze-voorlichting gaat het immers om de relatieve verschuivingen.

Tabel 8.3 geeft een overzicht van kwaliteit van de BLS prognoses voor 1990 en de ROA-prognoses tot 1994. Uit de tabel blijkt dat de score van de ROA-prognoses wat gunstiger is dan de score van BLS. Deze lagere score wordt vooral veroorzaakt door een lager gemiddeld verlies van de ROA-prognoses. Het verschil in het gemiddeld verlies van $S A B$ is minder groot. Het gemiddeld verlies van de prognose en $S A B$ is echter moeilijk tussen beide landen vergelijkbaar doordat beide prognoses in allerlei opzichten van elkaar verschillen. Afgezien van het schaaleffect kan echter verwacht worden dat SAB in gelijke mate last heeft van de anderssoortige omstandigheden als de feitelijke prognoses. De onderlinge vergelijking van de scores lijkt dus meer op zijn plaats dan de vergelijking van het gemiddeld verlies.

Tabel 8.3

Een vergelijking van de voorspelkwaliteit van de ROA- en BLS-uitbreidingsvraagprognoses

\begin{tabular}{llll}
\hline & $\begin{array}{l}\text { Gem. verlies } \\
\text { prognose }\end{array}$ & $\begin{array}{l}\text { Gem. verlies } \\
\text { SAB }\end{array}$ & Score \\
\hline BLS & 0,0472 & 0,0654 & 0,72 \\
ROA & 0,0352 & 0,0600 & 0,59 \\
\hline
\end{tabular}

Als het verband tussen schaal en score wordt onderzocht blijkt BLS relatief beter te scoren bij de grote beroepsklassen, terwijl de ROA-prognoses met name goed zijn voor de kleinere beroepsklassen. Omdat de schaalverschillen tussen Nederland en de VS enorm groot zijn - zo kennen de VS in 1990 bijna vier miljoen secretaresses betekent dit dat de verwachte score van de BLS-prognoses zou toenemen als deze op de ROA-classificatie wordt geprojecteerd, maar omgekeerd de ROA-prognoses in de BLS-classificatie nog veel meer zouden verslechteren. Het zou hierbij echter gaan om een vergelijking van prognoses van beroepsklassen die volledig buiten het Nederlandse domein liggen. 
Figuur 8.1

De standaardfout van de ROA-prognoses en BLS-prognoses voor beroepen met minder dan 250.000 werkenden.

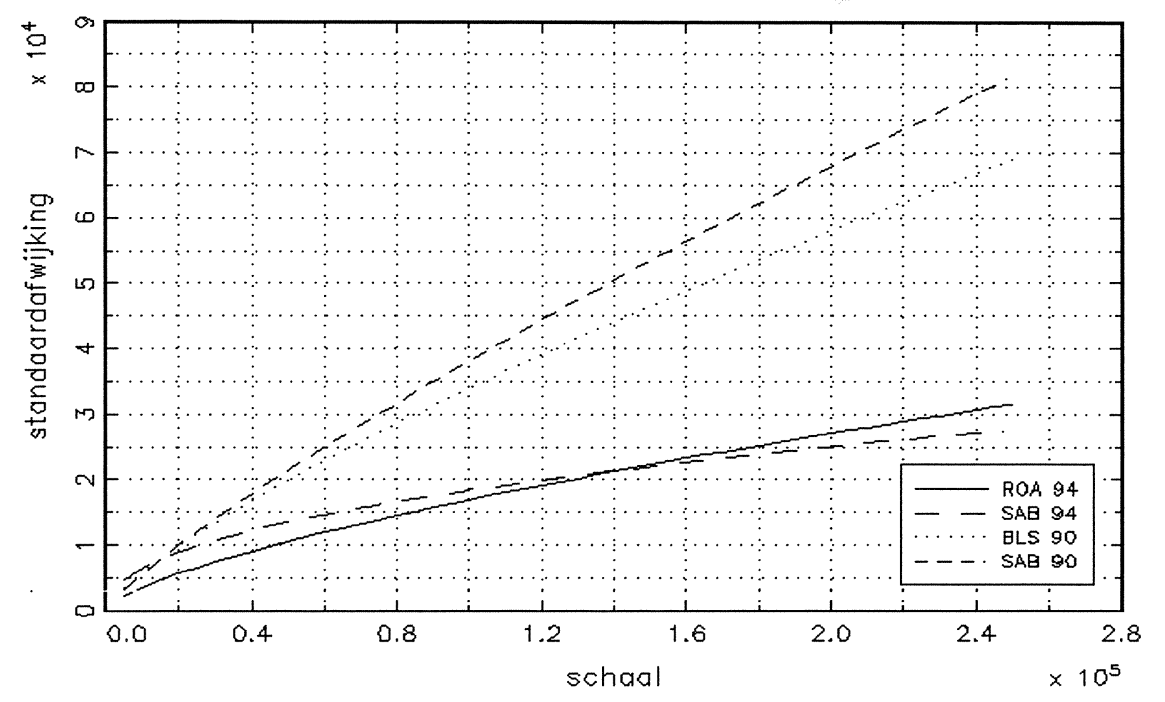

In figuur 8.1 is daarom een dergelijke vergelijking gemaakt voor de prognoses van beroepsklassen met minder dan 250.000 werkenden. Zowel de standaarddeviatie van de prognoses als van SAB blijken in Nederland aanmerkelijk kleiner te zijn als gecorrigeerd wordt voor de schaal. Figuur 8.2 geeft de bijbehorende scores. Ook hier blijken de ROA-prognoses met name de kleinere beroepsklassen goed te voorspellen, terwijl de BLS-voorspellingen met name voor de grotere beroepsklassen gunstig uitpakken. Dit bevestigt de bevindingen in hoofdstuk 3 dat met name voor grote beroepsklassen modellen van de trends in de beroepenstructuur weinig toegevoegde waarde hebben.

Tabel 8.4, 8.5 en 8.6 geven voor de beroepsklassen met maximaal tot 250.000 werkenden aan hoe de prognosekwaliteit afhangt van de gehanteerde classificatie. Evenals naar voren kwam bij de vergelijking van de ROA-indeling met de CBSberoepenindeling blijkt ook hier de ROA-beroepenclassificatie evenwichtiger te zijn samengesteld. Dit blijkt uit het feit dat het gemiddeld verlies voor zowel SAB als de feitelijke prognoses van zowel BLS als ROA een hoger gemiddeld verlies hebben bij de ROA-classificatie. Zoals reeds eerder werd opgemerkt wordt het gemiddeld verlies hoger als de onderscheiden beroepsklassen minder qua omvang uiteenlopen. De verlaging van het gemiddeld verlies door een grotere beroepsklasse wordt niet volledig teniet gedaan door de stijging van het gemiddeld verlies vanwege een kleinere beroepsklasse. 
Figuur 8.2

De relatieve standaardfout van de ROA-prognoses en BLS-prognoses voor beroepen met minder dan 250.000 werkenden.

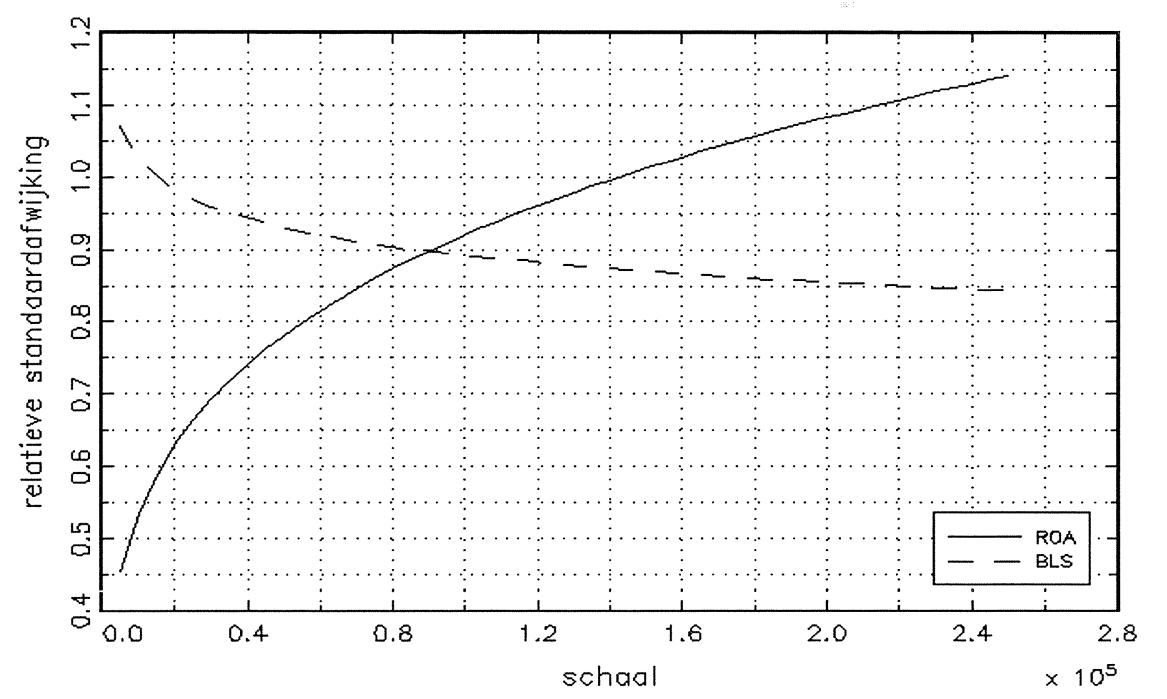

Tabel 8.4

De relatie tussen het verwachte gemiddeld verlies van de prognoses en de classificatie voor beroepen met minder dan 250.000 werkenden

BLS

ROA

Classificatie BLS

0,1103

0,0276

Classificatie ROA

0,1411

0,0395

Tabel 8.5

De relatie tussen het gemiddeld verlies van $S A B$ en de classificatie voor beroepen met minder dan 250.000 werkenden

BLS ROA

Classificatie BLS

0,1391

Classificatie ROA

0,1658

0,0742 
Tabel 8.6

De relatie tussen de score en de classificatie voor beroepen met minder dan 250.000 werkenden

\begin{tabular}{lll}
\hline & BLS & ROA \\
\hline Classificatie BLS & 0,79 & 0,73 \\
Classificatie ROA & 0,85 & 0,53 \\
\hline
\end{tabular}

Omdat dit effect optreedt bij zowel de prognoses als de SAB, is dit beeld bij de vergelijking van de scores genuanceerder. Omdat met name de BLS-prognoses goed scoren bij de grotere beroepsklassen en ROA betere resultaten laat zien bij de kleinere beroepsklassen, scoort elk instituut met name goed in de eigen classificatie. Het score-verschil tussen ROA en BLS zou daarom aanmerkelijk kleiner zijn als gekeken wordt naar de BLS-classificatie, maar het verschil wordt groter als de ROAclassificatie als uitgangspunt wordt genomen. De ROA-methodiek is dus met name gunstig bij beroepsklassen die een voor Nederland gemiddelde omvang hebben. 


\section{Conclusies}

In dit rapport zijn de arbeidsmarktprognoses naar opleiding en beroep tot 1994 van het Informatiesysteem Onderwijs-Arbeidsmarkt geëvalueerd. Het is de tweede maal dat de prognoses van het ROA zijn geëvalueerd, zodat een vergelijking van de voorspelkwaliteit van de prognoses tot 1994 met die van de prognoses tot 1992 mogelijk is. Daarnaast is in dit rapport een vergelijking gemaakt tussen de uitbreidingsvraagprognoses van het ROA en vergelijkbare prognoses van het Bureau of Labor Statistics voor de Verenigde Staten.

In dit slothoofdstuk wordt in het kort een overzicht gegeven van de belangrijkste bevindingen. Dit gebeurt aan de hand van een drietal tabellen. Tabel 9.1 geeft een overzicht van de belangrijkste kencijfers van de evaluatie waarbij telkens de vergelijking met de prognoses tot 1992 wordt gemaakt. In tabel 9.2 is een aantal modelveranderingen opgesomd die tussen de prognoses tot 1992 en de hier geëvalueerde prognoses tot 1994 zijn aangebracht. Hierbij wordt telkens aangegeven welke invloed deze veranderingen hebben gehad op de prognosekwaliteit. Ten slotte is in tabel 9.3 aangegeven welke aanpassingen in de prognosemethodiek aanbevolen worden op grond van de evaluatieresultaten uit dit rapport. Deels zijn dergelijke veranderingen sindsdien al doorgevoerd, zodat een onderscheid wordt gemaakt tussen doorgevoerde en nog door te voeren veranderingen.

Tabel 9.1 laat zien dat bij de prognoses tot 1992 verreweg het grootste gemiddeld verlies optrad bij de uitbreidingsvraagprognoses per beroepsklasse. Het gemiddeld verlies van deze prognoses is echter aanzienlijk afgenomen. Thans blijkt - hoewel dit cijfer negatief beïnvloed kan zijn door verschuivingen in de gehanteerde informatiebronnen - dat de arbeidsmarktinstroomprognoses het grootste gemiddeld verlies kennen. Deze component is overigens in de vorige evaluatie niet geëvalueerd. Verder blijkt dat ook bij de SKILL-prognoses het gemiddeld verlies is toegenomen.

Relatief gezien de grootste reductie van het gemiddeld verlies trad op bij de vervangingsvraag per beroepsklasse. Het gemiddeld verlies nam hier maar liefst met bijna $90 \%$ af. Deze vooruitgang werd veroorzaakt doordat dit maal geen uitstroomprognoses, maar daadwerkelijk vervangingsvraagprognoses werden opgesteld. Daardoor werd ook implicitiet overgestapt van de veronderstelling dat de uitstroomfracties stabiel zijn in de tijd, op de veronderstelling dat de vervangingsvraagfracties stabiel zijn. Hoewel de werkelijkheid ergens tussen deze twee uitersten in lijkt te liggen, is voor de prognosekwaliteit de tweede aanname aanmerkelijk beter. Ook bij de vervangingsvraag naar opleidingstype resulteerde deze overstap in een aanzienlijke vermindering van het gemiddeld verlies. 
Wanneer wordt gekeken naar de score - dat is het gemiddeld verlies gerelateerd aan dat van een referentieprognose - dan komt een ander beeld naar voren. In dat geval blijkt de voornaamste vooruitgang te zijn geboekt bij de uitbreidingsvraagprognoses. De genoemde verbetering bij de vervangingsvraag komt in deze cijfers niet tot uitdrukking, omdat ook de referentieprognose is aangepast van een arbeidsmarktuitstroomprognose naar een vervangingsvraagprognose. Vanwege meetproblemen blijkt de precieze omvang van de vervangingsvraag minder goed voorspeld te zijn dan bij de referentieprognose. Ook de SKILL-prognoses van het aantal gediplomeerden per studierichting scoorden - in tegenstelling tot de prognoses tot 1992 - slechter dan de referentieprognose.

De puntprognoses op basis van de prognosemodellen zijn telkens omgezet in kwalitatieve typeringen. De tabel geeft aan welk deel van deze kwalitatieve typeringen exact juist zijn, en welk deel hoogstens één klasse naast de juiste typering zit. Bij alle prognosecomponenten blijkt de voorspelkwaliteit van de kwalitatieve typeringen in vergelijking met de vorige evaluatie te zijn toegenomen. De vervangingsvraag per opleidingstype blijkt de laagste trefkans te hebben, $60 \%$ van de typeringen is goed of vrijwel goed. Opvallend hoog is de voorspelkwaliteit van de kwalitatieve typeringen van de arbeidsmarktinstroomprognoses. Maar liefst $98 \%$ van de typeringen blijkt vrijwel goed of goed te zijn. Dit relativeert de eerdere bevindingen met betrekking tot het gemiddeld verlies van deze prognosescomponent. Dit opmerkelijke verschil wordt veroorzaakt doordat de typeringen van de arbeidsmarktinstroom per opleidingstype gerelateerd zijn aan de omvang van de werkzame bevolking met de desbetreffende opleidingsachtergrond.

Tabel 9.2 gaat in op de effecten van een aantal veranderingen in de prognosemethodiek op de voorspelkwaliteit van de prognoses, terwijl tabel 9.3 aangeeft welke veranderingen in de prognosemethodieken op grond van de evaluatieresultaten aan te bevelen zijn. Allereerst had zowel bij de uitbreidingsvraag- als de vervangingsvraagprognoses de overstap naar de ROA-beroepenclassificatie een gunstige invloed op de score's. Het gemiddeld verlies nam weliswaar toe door het gebruik van deze meer gelijkmatige indeling, maar omdat de gebruikte modellen met name de kleinere beroepsklassen goed voorspellen in vergelijking met de referentieprognose, onstond er per saldo toch een winst in de voorspelkwaliteit. De overige aanpassingen van het uitbreidings-vraagmodel hebben een minder duidelijk waarneembare invloed op de prognosekwaliteit. Het feit dat de werkgelegenheidsontwikkeling per beroepsklasse kan variëren per bedrijfssector heeft waarschijnlijk bijgedragen aan de verbeterde voorspelkwaliteit, maar het sterk teruggenomen gebruik van trendvariabelen heeft waarschijnlijk een negatieve invloed op de prognosekwaliteit gehad. Ook bij de vorige evaluatie werd ingegaan op het dilemma tussen het ten onrechte negeren van trends en het gevaar van het opnemen van trends die slechts op statistisch toeval berusten. Verder blijkt ook BLS moeite met 
deze afweging te hebben. Inmiddels is met behulp van het random-coëfficiëntenmodel een middenweg tussen deze twee uitersten gevonden. Een ander aspect met betrekking tot de methodiek van de uitbreidingsvraag per beroepsklasse dat nog opgelost moet worden, is dat de huidige methodiek onvoldoende rekening houdt met mogelijke omslagen in de trendmatige ontwikkeling. Zeker nu er langere tijdreeksen ter beschikking komen wordt dit een urgenter probleem. Verder zal nader onderzoek gedaan moeten worden naar belangrijke verklarende variabelen, en zal bekeken moeten worden of het zinvol is het aantal onderscheiden bedrijfssectoren te vergroten.

De meest opvallende verbetering betreft de al eerder genoemde overstap van arbeidsmarktuitstroom- naar vervangingsvraagprognoses. De methodiek met betrekking tot de vervangingsvraag die voor de prognoses tot 1994 is gehanteerd blijkt echter erg gevoelig te zijn voor meetfouten. Inmiddels zijn in dit opzicht al een aantal verbeteringen aangebracht. Ten eerste worden zowel de prognoses als de onderliggende parameters systematisch op hun plausibiliteit getoetst. Daarnaast zijn de arbeidsmarktuitstroomcoëfficiënten niet meer gebaseerd op de vergelijking van slechts twee jaren, maar worden meerdere waarnemingsjaren in de analyse betrokken. Ten slotte is ook voor de vervangingsvraag een random-coëfficiëntenmodel ingevoerd, waarmee grote uitbijters in de schattingsresultaten worden vermeden. In de toekomst zal de samenhang tussen de vervangingsvraag en uitbreidingsvraag expliciet in het model moeten worden opgenomen. In de eerste plaats gaat het hier om het verband tussen krimpende werkgelegenheid en de uitstroomcoëfficiënten. Daarnaast dient bij de vervangingsvraag naar opleidingstype ook onderzocht te worden in hoeverre de aannames die gemaakt worden met betrekking tot de verschuivingen in de gevraagde kwalifacties consistent zijn met de aannames in het uitbreidingsvraagmodel. Ten slotte kan de informatieve waarde van het informatiesysteem vergroot worden, als er gegevens beschikbaar komen over arbeidsmarktstromen in de werkgelegenheid. Met behulp van bijvoorbeeld de retrospectieve vraag in de EBB zouden ook herintreders expliciet in de analyse betrokken kunnen worden.

De arbeidsmarktinstroomprognoses hebben zowel een sterke als een zwakke kant. Doordat de gebruikte modellen zeer goed de min of meer structurele verschillen in het aanbod van schoolverlaters op de arbeidsmarkt aangeven, hebben ze een sterk positieve invloed op de voorspelkwaliteit van de arbeidsmarktperspectieven. De prognoses blijken echter relatief slecht de veranderingen in het instroompatroon te voorspellen. Dit wordt enerzijds veroorzaakt door de matige kwaliteit van de SKILLprognoses. In dit opzicht is de vraag van belang in hoeverre de Referentieraming, die de opvolger is van de SKILL-prognoses, een verbetering van de prognoseskwaliteit heeft opgeleverd. Met betrekking tot de verbijzondering van de SKILL-prognoses is inmiddels een verbetering aangebracht in de prognose- 
methodiek door een modelaanpassing waardoor enerzijds trends in de verdeelcoëfficiënten worden doorgetrokken, maar anderzijds de eenmalige fluctuaties in de tijdreeksen zoveel mogelijk worden genegeerd. Verder wordt meer en meer gebruik gemaakt van informatie uit de schoolverlatersenquêtes, waardoor bijvoorbeeld een betere informatie beschikbaar is over de mate waaring leerlingen doorstromen in het vervolgonderwijs. Ten slotte dient de informatievoorziening met betrekking tot het niet-reguliere onderwijs verder te worden gesystematiseerd en te worden afgestemd op de mate waarin in de EBB niet-reguliere opleidingen niveauverhogend onderwijs blijken te zijn. 


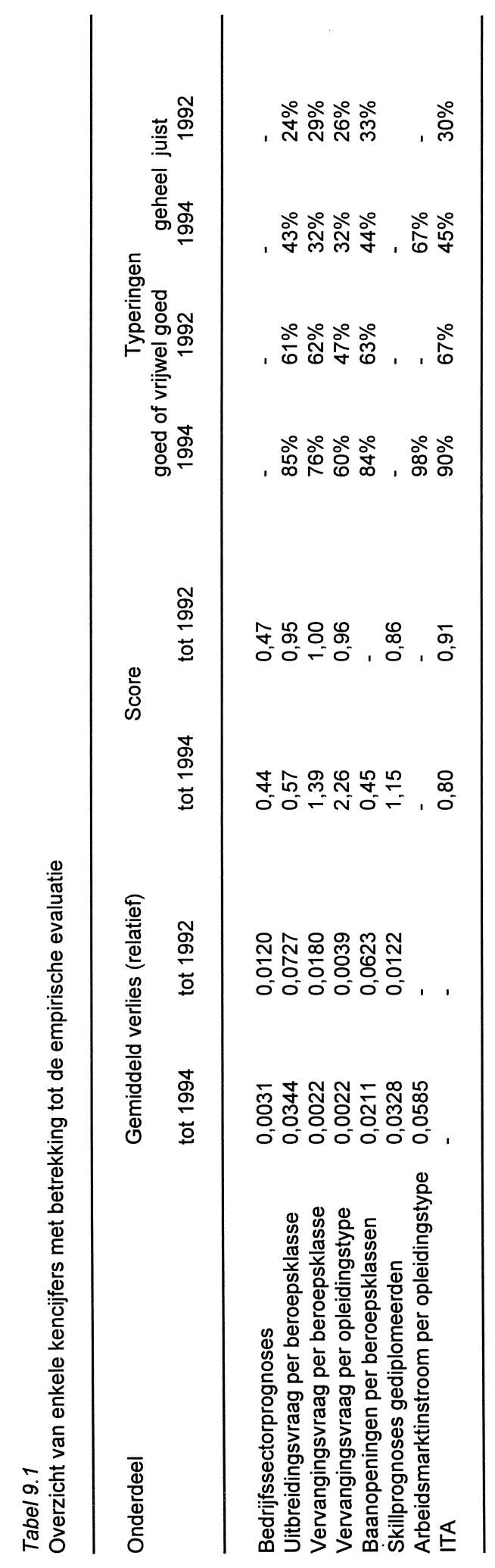




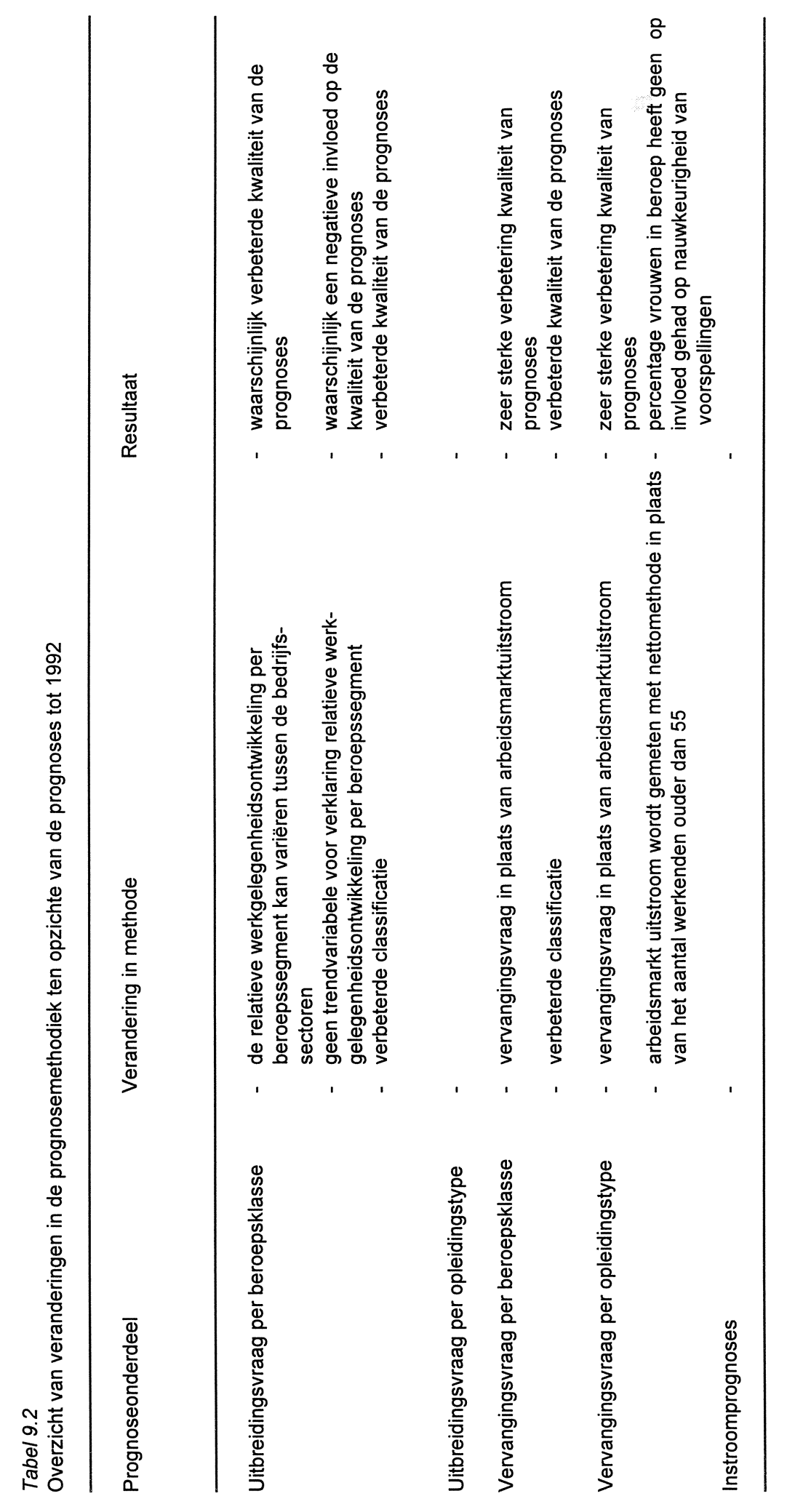




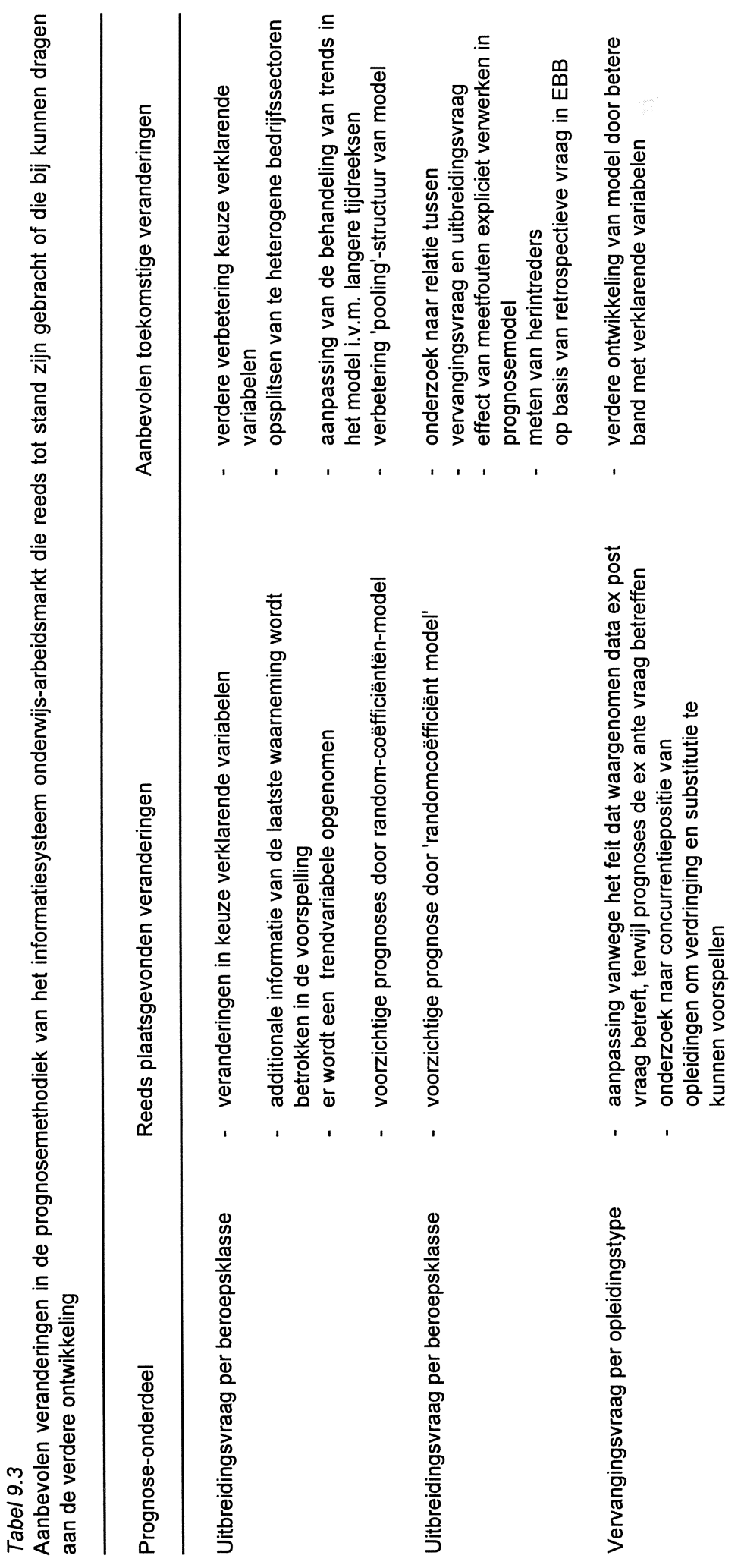




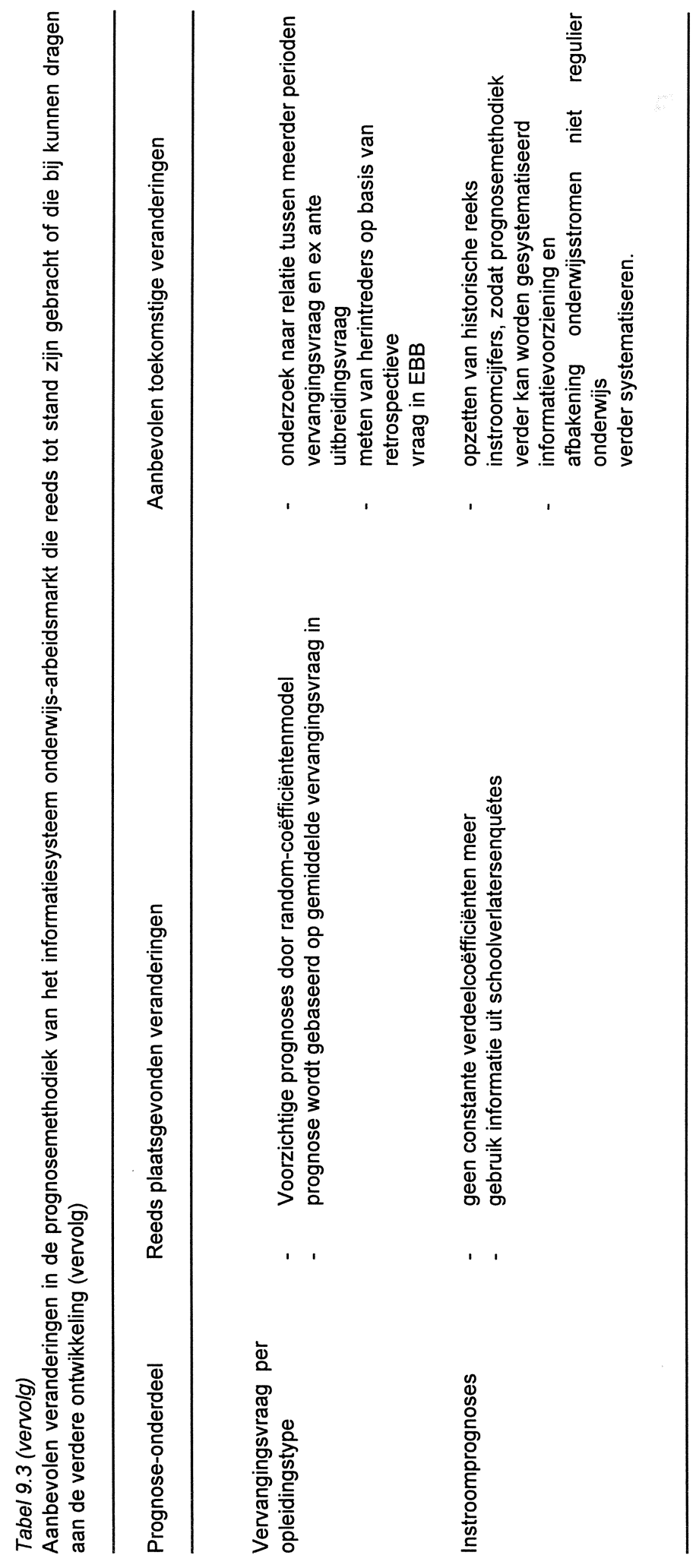




\section{Literatuur}

Berendsen, H., A. de Grip, M.H. Wieling, E.J.T.A. Willems (1992), Arbeidsmarktinformatie naar opleiding en beroep voor de provincie Friesland: tabellenoverzicht, ROA-W-1992/4, Maastricht.

Bishop, H.J., S. Carter (1991), How Accurate are Recent BLS Occupational Projections, Monthly Labour Review, oktober 1991, pp. 37-43.

Borghans, L. (1993), Educational Choice and Labour Market Information, proefschrift Maastricht.

Borghans, L. , P. van Eijs, A. de Grip (1994), Evaluatie arbeidsmarktprognoses naar opleiding en beroep in 1992, ROA-R-1994/4, Maastricht.

Borghans, L., A. de Grip, E. Willems (1995), Herijking ROA-Informatiesysteem OnderwijsArbeidsmarkt, ROA-R-1995/1, Maastricht.

Borghans, L., H. Heijke (1994), Een random coëfficiëntenmodel voor het voorspellen van de beroepenstructuur van bedrijfstakken, ROA-W-1994/1. Maastricht.

Borghans, L., J.A.M. Heijke (1996), Forecasting the Educational Structure of Occupations: A Manpower Requirement Approach with Substitution, Labour, pp. 151-192

Borghans, L., A. Matheeuwsen (1996), Forecasting educational outflow per type of education, ROA-RM, verschijnt binnenkort

Carey, M.L. (1980), Evaluating the 1975 projections of occupational employment, Monthly Labor Review, juni 1980, pp.10-21.

Carey M.L., K. Kasunic (1982), Evaluating the 1980 projections of occupational employment, Montly Labor Review, juli 1982, pp. 22-30.

Dekker, R.J.P., A. de Grip, H. Berendsen, M.H. Wieling, E.J.T.A. Willems (1992), Methodiek en structuur arbeidsmarktmodule I-See! 1991, ROA-W-1992/1, Maastricht.

Dekker, R.J.P., A. de Grip, P.J.E. van de Loo (1990), ROA-Beroepenclassificatie 1990, ROAW-1990/9, Maastricht.

Eijs, P. van (1994), Manpower Forecasting in the Western World: The Current State of the Art, ROA-RM-1994/1E, Maastricht.

Granger, C.W.J., P. Newbold (1986), Forecasting Economic Time Series, Orlando.

Grip, A. de, L.F.M. Groot, J.A.M. Heijke (1991), Defining Occupational Groupings by Educational Structure, Environment and Planning A, vol. 23, pp. 59-85.

Grip, A. de, J.A.M. Heijke en H. Berendsen (1991), Eerste evaluatie informatiesysteem onderwijs-arbeidsmarkt, ROA-R-1991/1, Maastricht.

OECD (1994), Employment Outlook, Parijs.

Peeters, H.M.M. (1990), An Explanation of the Occupational and Educational Structure of Employment by Means of Multinomial Logit, ROA-W-1990/4E, Maastricht.

ROA (1991), De arbeidsmarkt naar opleiding en beroep tot 1994, Prototype, ROA-R-1991/5, Maastricht.

ROA (1992a), De arbeidsmarkt naar opleiding en beroep tot 1994, ROA-R-1992/1, Maastricht.

ROA (1992b), De arbeidsmarkt naar opleiding en beroep tot 1994. Statistische Bijlage, ROA-R1992/1B, Maastricht.

ROA (1993a), De arbeidsmarkt naar opleiding en beroep tot 1998, ROA-R-1993/10, Maastricht.

ROA (1993b), De arbeidsmarkt naar opleiding en beroep tot 1998. Statistische Bijlage, ROA-R1993/10B, Maastricht.

ROA (1995a), De arbeidsmarkt naar opleiding en beroep tot 2000, ROA-R-1995/3, Maastricht.

ROA (1995b), De arbeidsmarkt naar opleiding en beroep tot 2000. Statistische Bijlage, ROA-R- 
1995/3B, Maastricht.

Rosenthal, N.H. (1992), Evaluating the 1990 projections of occupational employment, Monthly Labor Review, augustus 1992, pp. 32-48.

Theil, H. (1958). Economic Forecasts and Policy, Amsterdam.

Wieling, M., L. Borghans (1995), Discrepancies between Demand and Supply and Adjustment Processes on the Labour Market, ROA-RM-1995/4E, Maastricht.

Willems, E.J.T.A., A. de Grip (1993), Forecasting Replacement Demand by Occupation and Education, International Journal of Forecasting, vol. 9, pp. 173-185. 

realisatie:

$\times \quad \theta>0 \quad$ onderschatting van verandering

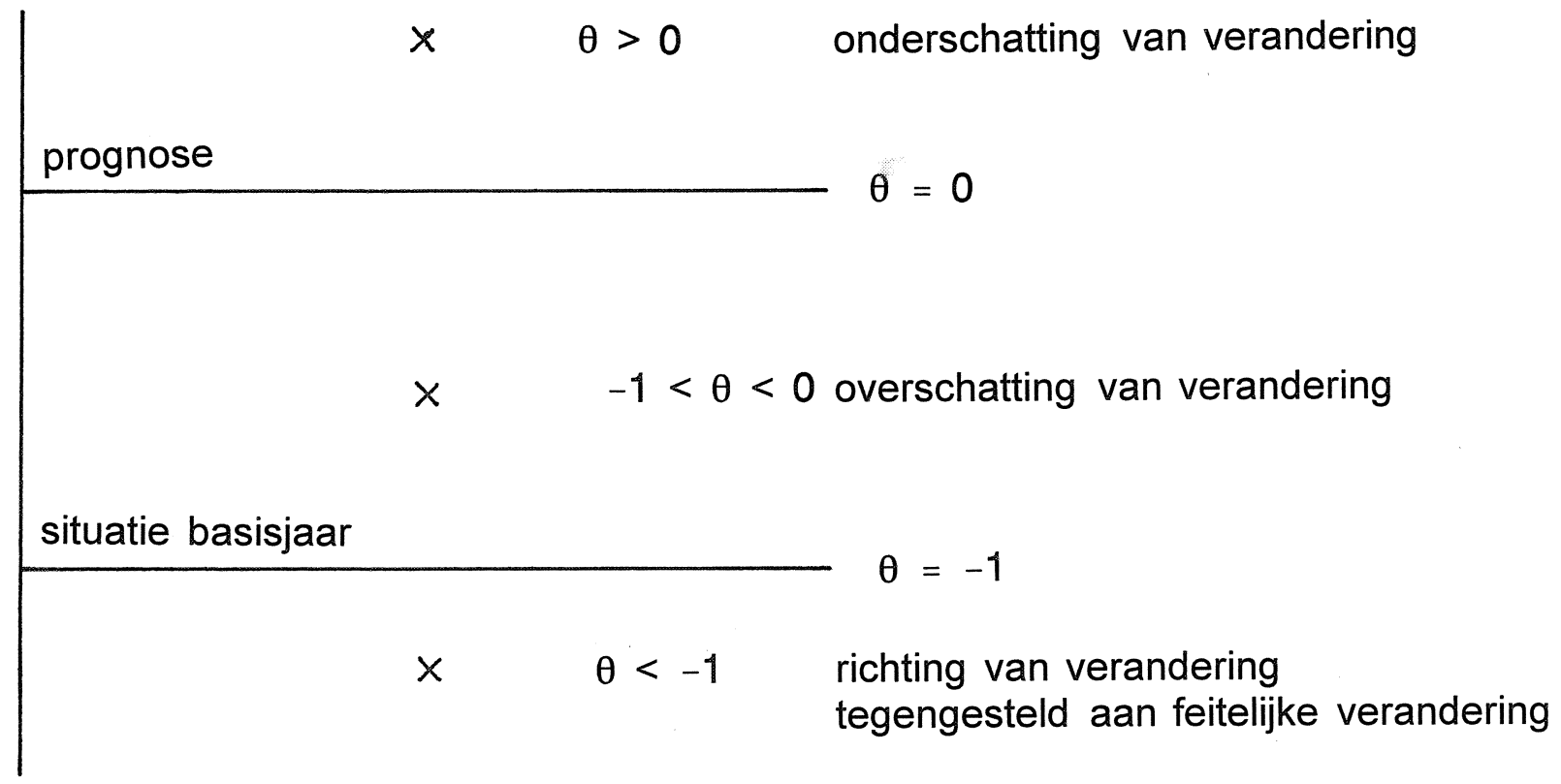

Figuur 21 op pagina 17 

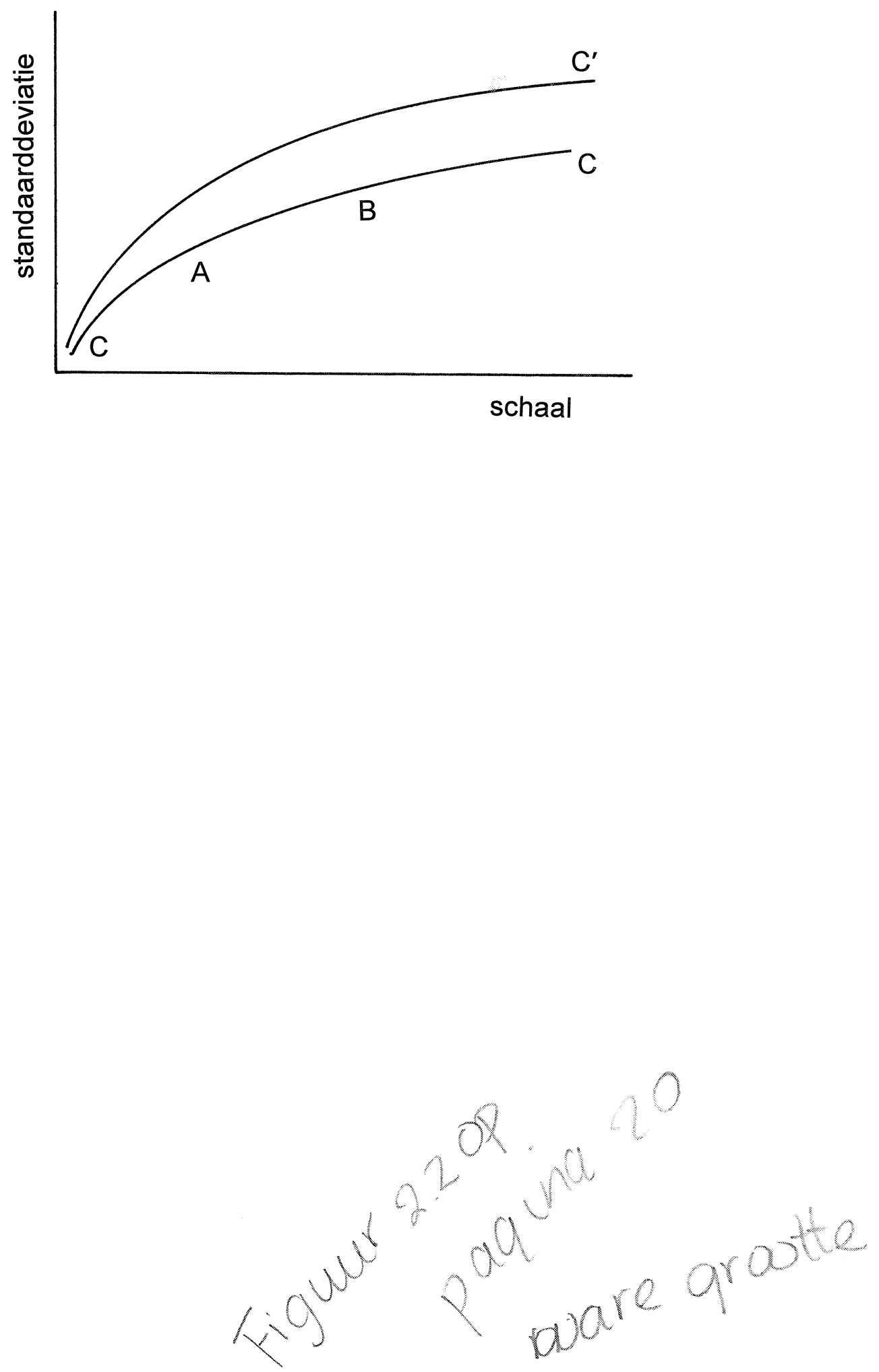
Figuur 2.1. Stromen op de arbeidsmarkt

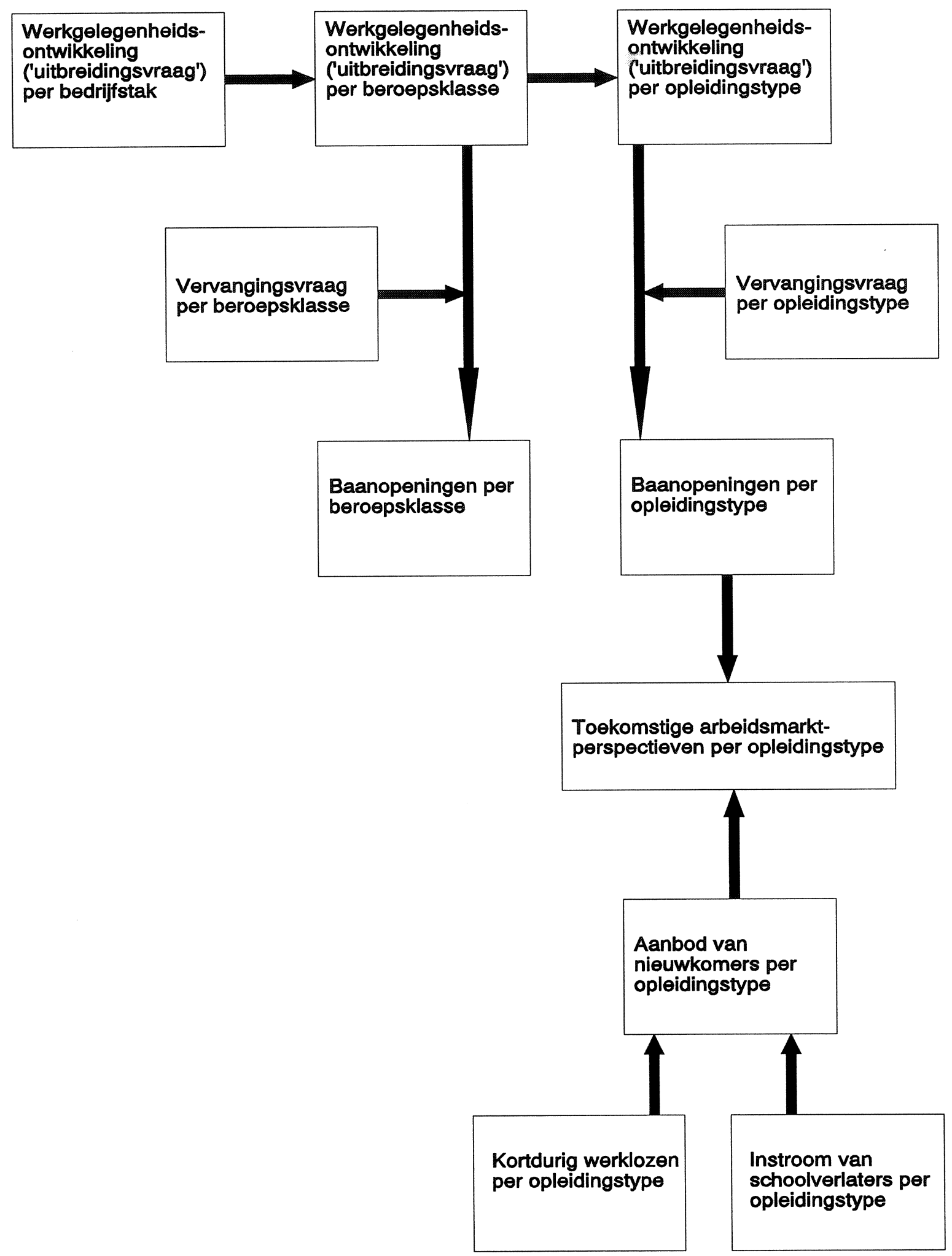

Figuur.' op pagina 7 